Portland State University

PDXScholar

\title{
Ecosystem Engineering in the Backwater Wetlands of the Lower Columbia: Feature Specific Testing of the Virginia Lake Stake Alignment
}

Michelle Noel North

Portland State University

Follow this and additional works at: https://pdxscholar.library.pdx.edu/open_access_etds

Part of the Anthropology Commons

Let us know how access to this document benefits you.

\section{Recommended Citation}

North, Michelle Noel, "Ecosystem Engineering in the Backwater Wetlands of the Lower Columbia: Feature Specific Testing of the Virginia Lake Stake Alignment" (2020). Dissertations and Theses. Paper 5434. https://doi.org/10.15760/etd.7307

This Thesis is brought to you for free and open access. It has been accepted for inclusion in Dissertations and Theses by an authorized administrator of PDXScholar. Please contact us if we can make this document more accessible: pdxscholar@pdx.edu. 
Ecosystem Engineering in the Backwater Wetlands of the Lower Columbia:

Feature Specific Testing of the Virginia Lake Stake Alignment

by

Michelle Noel North

A thesis submitted in partial fulfillment of the requirements for the degree of

Master of Science

in Anthropology

Thesis Committee:

Virginia L. Butler, Chair

Shelby L. Anderson

Douglas C. Wilson

Portland State University 2020 
(C) 2020 Michelle Noel North 


\section{Abstract}

There is a growing interest in anthropology towards identifying and documenting the ways in which people have modified landscapes and ecosystems through time. Previous research has focused predominantly on terrestrial modification, whereas recently, research has turned towards aquatic environments. Examples range from the tidal fish pens of Hawai'i to fish weir complexes and clam gardens on the Northwest Coast. Scholars are beginning to apply the term human ecosystem engineering to the practices linked to wetland landscape modifications. Evidence of these practices can contribute to understanding optimization, cultivation, and modification of aquatic environments on a landscape level. However, some regions have received more consideration than others; the backwater wetlands of the Lower Columbia are minimally studied.

Lower Columbia archaeological and ethnohistoric records highlight the importance of aquatic plants and mammals that inhabit wetland environments; freshwater fish remains from families Catostomidae and Cyprinidae are prominent in regional archaeological site assemblages. This raises questions as to how wetland resources in the region were used and potentially optimized in the broader context of the backwater ecosystem, and how this ecosystem has been modified by humans. A wood stake alignment located on Sauvie Island in Virginia Lake, a seasonally flooded backwater, offered a starting place to examine these questions.

I conducted archival research, pedestrian survey, site mapping, subsurface testing, and laboratory analysis to evaluate hypotheses related to the feature's age 
(precontact, historic, and multicomponent), cultural affiliation (Indigenous, EuroAmerican, or both), and function (fish weir, causeway/pier, hunting platform or blind, post and line structure for straightening/storing cedar planks, boundary line/fence, or multi-use). Results from Virginia Lake were compared to four sites containing wood stake/post alignments in Lower Columbia River wetlands. Niche Construction Theory and Historical Ecology informed my analyses.

Fieldwork and site documentation were conducted at two scales; landscape-level and site-specific, and included pedestrian survey, metal detector survey, and excavation of 11 subsurface shovel probes, and two $1 \times .5 \mathrm{~m}$ test units. Six wood samples and one sediment sample were submitted for AMS dating and macrobotanical identification. Toolmarks were analyzed to determine if the stakes were shaped using metal or stone tools.

The alignment (northeast/southwest orientation) consists of a total of 23 wooden stakes that extend approximately $60 \mathrm{~m}$ from the lake edge. Stakes average $5.9 \mathrm{~cm}$ in diameter, and $25.6 \mathrm{~cm}$ height above ground surface, but stakes are not uniform in size or condition. Stakes are spaced an average of $2.5 \mathrm{~m}$ apart. The five sampled stakes are from western red cedar (Thuja plicata). Except for two small metal fragments found within two stakes, additional artifacts were not observed in association with the alignment. One of the removed stakes with an intact distal end appears to have been shaped with a metal tool, likely a chisel or axe. Calibrated median AMS dates fall within a tight range, between 1847 and 1854 CE. AMS dating of humin fraction of a peat sample obtained during excavations returned a calibrated date of between 969 and 1035 CE (925-981 BP). 
This date suggests that Virginia Lake has been separate from the main Multnomah Channel for at least the last approximately 1000 years.

Though the AMS ages indicate an historic era construction, the feature could reflect Euro-American or Indigenous affiliation, or links to both, given that archival records document a complex and ongoing relationship between Indigenous people and Euro-American settlers in the region through the $19^{\text {th }}$ century. Research eliminated four hypotheses related to function, leaving the possibility that the alignment was a fish weir or a pier. The Virginia Lake feature is distinct from other wood stake and post alignments documented on the Lower Columbia River making it difficult to place it in a larger system of ecosystem engineering and wetland modification.

My thesis contributes to the understanding of the history of Virginia Lake and its formation, and facilitates future work on wood stake features in backwater systems, which have been under-studied in the Pacific Northwest. Researchers cannot adequately test for specific site types, if there is little precedent for them to exist in a given environment. My thesis provides a methodological template for evaluating wetland landscape modifications, and more specifically stake sites, increasing replicability and a richer understanding of their role in human-modified landscapes. 


\section{Dedication}

For my mother

who was bold. 


\section{Acknowledgements}

This thesis was completed with the help, guidance, and encouragement of so many people. First, I would like to thank my advisor Dr. Virginia Butler for her many contributions to this document, and unwavering support during the writing process. Dr. Butler's enthusiasm and guidance have been indispensable in navigating obstacles both personal and academic during my time here. Thank you also to my committee members, Dr. Shelby Anderson and Dr. Doug Wilson, who provided much appreciated advice, and loaned me field equipment.

I would like to thank the Oregon Parks and Recreation Department, and Nancy Nelson, for allowing this project to proceed on their property, and for fielding my many questions during the permitting process.

I want to express my gratitude to The Confederated Tribes of Grand Ronde, The Confederated Tribes of Siletz Indians, and the Confederated Tribes of the Warm Springs, on whose lands this project takes place. Thank you in particular to the Confederated Tribes of Grand Ronde for taking the time to meet with me and for providing input.

I would like to thank all of the researchers, archaeologists, and specialists that provided information, advice, equipment, access to their work, help troubleshooting problems, and generally their unending patience, including Anna Neuzil, Brad Bowen, Chris Grant, Dale Croes, Geoffrey Duh, Kendal McDonald, Richard Brolley, Susanna Rawson, and TJ Brown. Thank you also to Gary Wessen and Melissa Darby for their information pertaining to 45CL31, and for a lovely afternoon visiting 45CL31 and Cathlapotle. 
My heartfelt gratitude to the Association of Washington Archaeology and the Oregon Archaeological Society for helping to fund this project. I could not have completed this work without your support. Thank you also to the archaeologists at WillametteCRA. You hired me in the middle of this, and believed me when I said I could finish. Thanks for your advice, for making me a better archaeologist, and mostly, for keeping me laughing and providing pie.

Thank you to the intrepid volunteers who braved wet weather and high grass to contribute their skills and help me complete this project. Specifically: Naomi Brandenfels, Nick Guest, Anthony Hofkamp, Kaitlyn Hosken, Patrick Rennaker, Trent Skinner, and Katherine Tipton. I owe a debt of gratitude to Dennis Torresdal, without whom this project would not have been possible. Thank you, Dennis, for identifying and reporting the site, working tirelessly with me on the field work, allowing us to stage on your property, providing a wealth of knowledge about Sauvie Island, and generally being so kind, welcoming, and insightful.

To my fellow graduate students, thank you for both commiserating with me during the tough times, and laughing with me during the good ones. You made the weeks shorter, and in particular Katie Tipton, for being my accountabilibuddy. Thank you always to Dr. Ken Ames, who inspired so many students, myself included. The horse brass will never be the same.

To my family; you may not have always understood what I was doing, but you never hesitated to encourage me. Your belief that I was capable of anything brought me 
here. Thank you also to my friends who fielded my phone calls, and reminded me of what matters.

Lastly, thank you to my partner, Patrick Reed. I could not have done this without your unwavering love and support. You are the most patient human on this planet. There is no one else I would have rather done this with and I can't wait to see what the future holds. 


\section{Table of Contents}

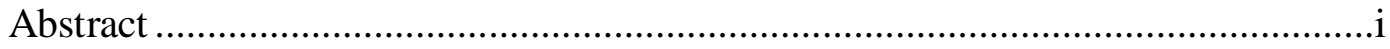

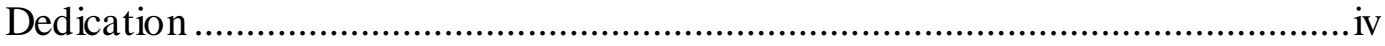

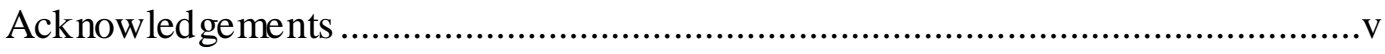

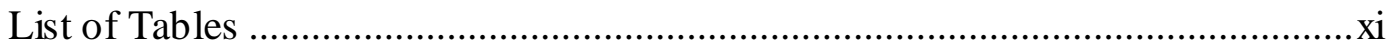

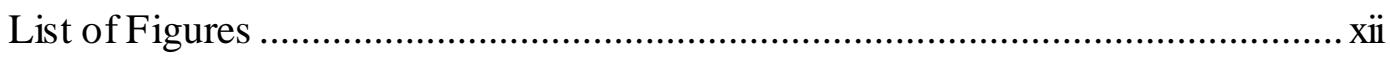

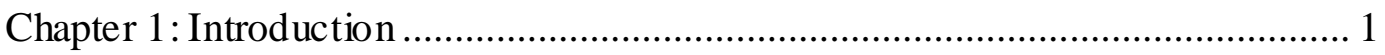

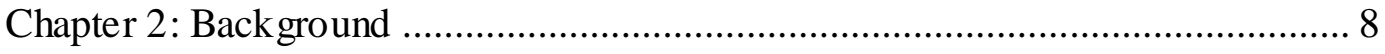

2.1 Lower Columbia Environmental History ………………............................ 8

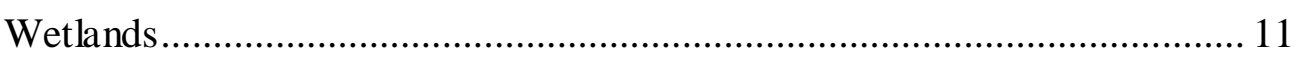

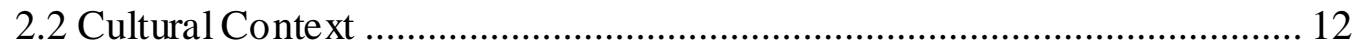

The Lower Columbia in Ethnography and Ethnohistory ............................... 12

Postcontact History of Sauvie Island ......................................................... 15

Lower Columbia Archaeology ................................................................... 18

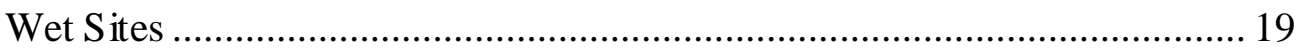

Wetland Cultural Constructions................................................................. 20

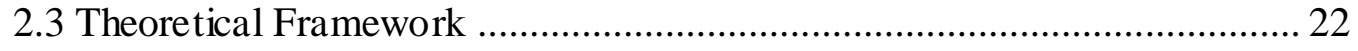

2.4 Questions and Hypotheses..................................................................... 25

Chapter 3: Methods and Materials ........................................................................ 27

3.1 Archival Research and Map Review ...................................................... 27

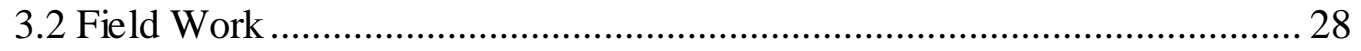

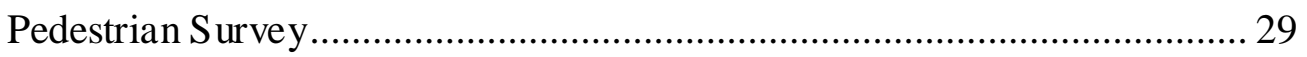

Feature Specific Testing and Documentation ................................................ 31 
Collection of Stake Samples ................................................................ 35

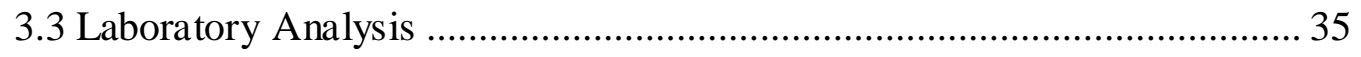

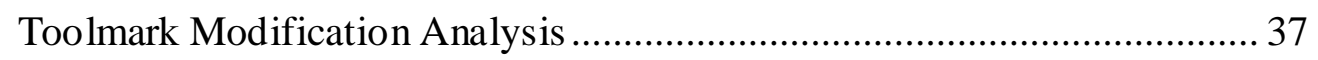

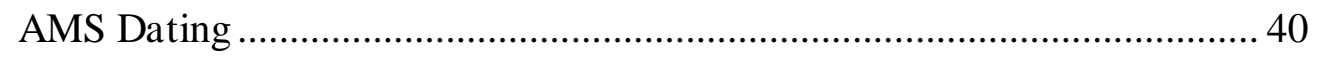

AMS Dating Using Humin Fraction .................................................... 42

Macrobotanical Identification ............................................................. 43

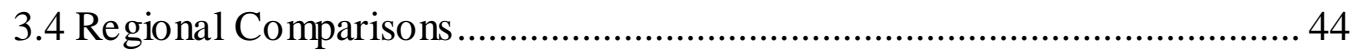

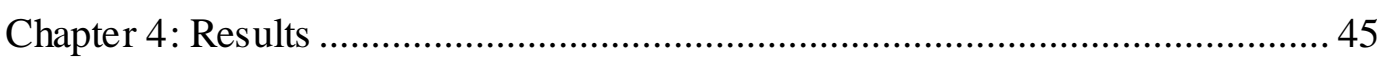

4.1 Archival Research and Map Review ................................................. 45

4.2 Field Work Results ........................................................................... 48

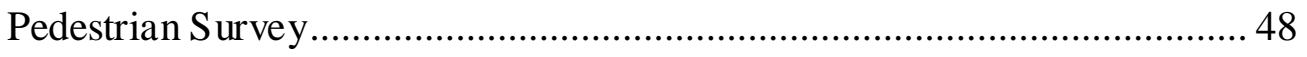

Overview of the Stake Alignment Feature ............................................... 53

Subsurface Shovel Probing and Feature Specific Testing ......................... 62

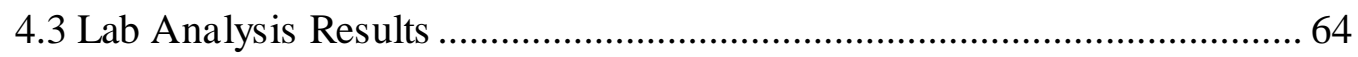

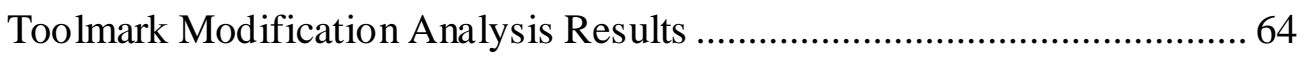

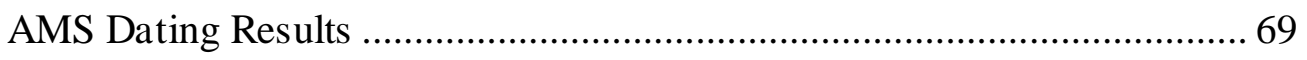

AMS Dating of Humin Fraction and Lake Formation .............................. 70

Macrobotanical Identification Results ................................................ 71

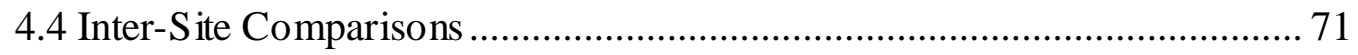

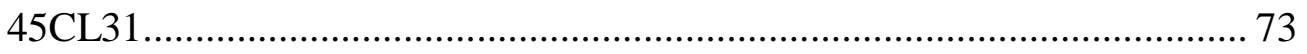

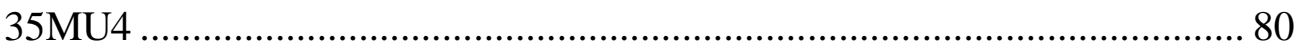

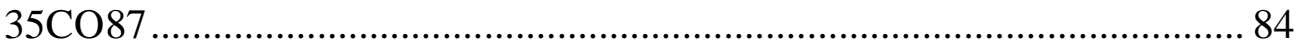

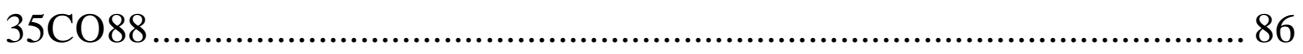

Chapter 5: Discussion and Conclusions ..................................................... 90 


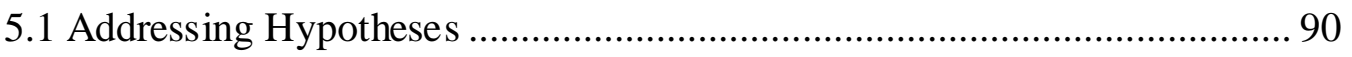

Question 1: What is the Age of the Feature? ................................................ 90

Question 2: What is the Cultural Affiliation of the Feature? .......................... 91

Question 3: What is the Function of the Feature?........................................ 92

Question 4: How Does the Feature Relate to Human Ecosystem Engineering in the Wetlands of the Lower Columbia? ................................................................ 109

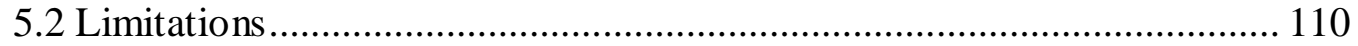

5.3 Broader Values and General Contributions .................................................. 111

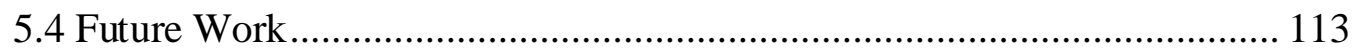

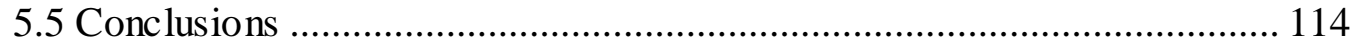

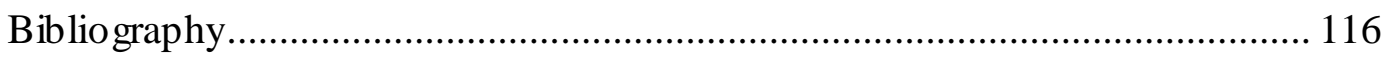

Appedix A: Oregon SHPO Archaeological Excavation Permit .......................... 129

Appedix B: OPRD Scientific Research Permit .................................................... 133

Appedix C:DirectAMS Reports ...................................................................... 139

Appedix D: Macrobotanical Identification Reports ............................................ 142

Appedix E: In-Situ Stake Recording Form .................................................. 145 


\section{List of Tables}

Table 1:List of main research questions, associated hypotheses, and outline of tasks

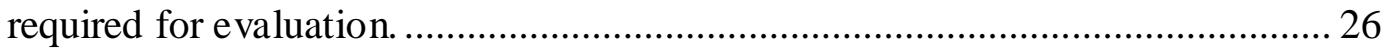

Table 2. Toolmark analysis variables, adapted from Arcas Associates (1986). ............... 39

Table 3. Features identified during pedestrian survey. .......................................... 51

Table 4. Overview of stakes in the Virginia Lake feature. ........................................ 59

Table 5. Arcas Associates (1986) tool mark classes and the tools used to produce them. 66

Table 6. Table created with information from Arcas As sociates (1986) tool classes 1-4. 66

Table 7. Results of Virginia Lake Stake 13 toolmark analysis measurements. ............... 67

Table 8. Uncalibrated results of AMS analysis ...................................................... 70

Table 9. Calibrated and modelled wood AMS dating results. .................................... 70

Table 10. Inter-site comparison of Lower Columbia wood stake sites.......................... 88 


\section{List of Figures}

Figure 1. Project Location Map. Insert displays the Willamette River and the Lower Columbia River from The Dalles to the Pacific Ocean.

Figure 2. Virginia Lake feature during a rare winter exposure, view east. Image courtesy

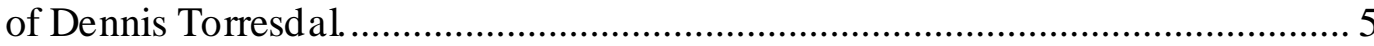

Figure 3: Sauvie Island and other village locations based on early $19^{\text {th }}$ century accounts, see Zenk et al. 2016 for corresponding village names..................................... 14

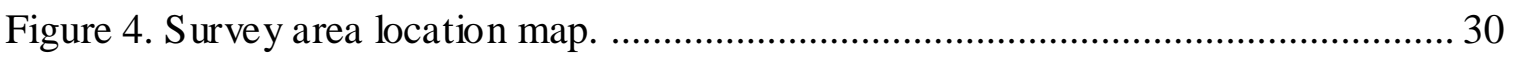

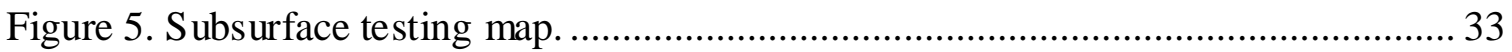

Figure 6. Virginia Lake feature stakes with number designation (* denotes stake sampled for AMS dating and macrobotanical identification) ....................................... 34

Figure 7. Toolmark modification analysis measurements diagram, image based on Arcas

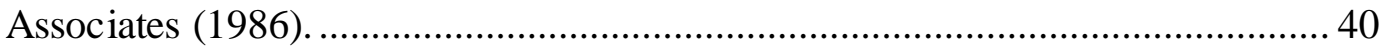

Figure 8. 1862 GLO map of Sauvie Island in the vicinity of Virginia Lake. .................. 46

Figure 9. 1854 GLO map of Sauvie Is land and the Virginia Lake vicinity. ................... 47

Figure 10. Overview of Virginia Lake survey area with abundant vegetation, view south.

Figure 11. LiDAR image depicting area surveyed. ................................................ 50

Figure 12. Locational map of features identified during pedestrian survey. ....................52

Figure 13. View northeast, possible hunting platform/blind made of dimensional lumber identified during pedestrian survey.

Figure 14. Virginia Lake stake alignment (note pairing towards top of photograph). View northeast, image courtesy of Dennis Torresdal. 55 
Figure 15. Virginia Lake stake alignment during 2018 fieldwork (blue flags mark stakes). View north.

Figure 16. Stake 7 (left), view west and Stake 3 (right), view southeast. Note difference in height. 58

Figure 17. Bar graph depicting relationship between stake height (measured from the ground surface) and position relative to the lake shore, with Stake 20 closest to shore, Stake 18 mid-lake.

Figure 18.TU2 level 6, base of unit, prior to removal of Stake 13 (left). Note Stake 14 oriented horizontally from the sidewall at right. 63

Figure 19. TU1 southwest wall profile, prior to removal of Stake 2. 64

Figure 20. Stake 13, distal end. 67

Figure 21. Stake 13, toolmarks 1 and 2 flagged. 68

Figure 22. Distal end of Stake 5, image courtesy of local landowner. 68

Figure 23. Location map of regional comparison sites 72

Figure 24. Sketch map of testing at 45CL31. Image adapted from Wessen (1983: B-18).

Figure 25. Distal end of stakes from 45CL31 (Wessen 1983).

Figure 26. Sketch map of the fish weir at 45CL31 in excavation Area E. Image adapted from Wessen (1983: B-60).

Figure 27. Eastern portion of the 45CL31 Vancouver Lake weir, view east (Wessen 1983). 78

Figure 28. Figure showing the probability distribution of the calibrated age of the 45CL31 weir. 79 
Figure 29. Distal end of removed wood stake from 35MU4. Photo taken September 14, 2006. Image courtesy of Ken Ames

Figure 30. Map of 2006/2007 testing at 35MU4. Map created by Michael Martin (Croes et al. 2009), used here with permission. 82

Figure 31. Overview of 35CO87, recorded horizonal timbers and rebar from 35CO87 in foreground, unrecorded pilings in background. View southeast (Neuzil 2018). .. 85

Figure 32. 35CO88, first group of pilings, view west (Neuzil 2018). 87

Figure 33. 1915 USGS Hillsboro 7.5 min quadrangle, feature location in red. 102

Figure 34. Ducks on Sauvie Island, 1957. Image courtesy of the Oregon Historical Society. 104

Figure 35. Hudson Bay era metal beaver trap, image courtesy of the Oregon Historical Society 105

Figure 36. Plank straightening structures. Image used with permission (Stewart 1984:43) 106 


\section{Chapter 1: Introduction}

There is a growing interest in anthropology towards identifying and documenting the ways in which people have modified landscapes and ecosystems through time (Deur and Turner 2005; Lepofsky and Caldwell 2013; Lightfoot et al. 2013; McKey et al. 2010; Thornton et al. 2015; Vale 2002). Previous research has focused predominantly on terrestrial anthropogenic modification (Anderson et al. 1997; Smith 2007; Turner et al. 2013; Vale 2002; Walsh 2008), whereas recently, research has turned towards both marine and freshwater aquatic environments (e.g. Campbell and Butler 2010b; Deur et al. 2015; Hoffmann et al. 2016; Thornton et al. 2015; Tushingham and Christiansen 2015). Examples range from freshwater taro/eel ponds of south-central Polynesia, to tidal fish pens of Hawai'i (Costa-Pierce 1987; Kirch 2017), and wetland agriculture and fisheries of Amazonia ((Erickson 2000; Fraser 2010; McKey et al. 2010). Scholars are beginning to apply the term human ecosystem engineering to the practices linked to wetland landscape modifications, highlighting the agency, scale, and intent of the people who engage in them.

These practices also extend to the Pacific Northwest, where anthropologists have identified archaeological, ethnographic, and ethnohistoric evidence of landscape modifications such as "clam gardens," "wapato gardens," and specialized behaviors and technologies relating to the cultivation and optimization of salmon and herring harvest (Butler and Campbell 2004; Campbell and Butler 2010b; Deur et al. 2015; Harper et al. 1995; Hoffmann et al. 2016; Thornton et al. 2015). Evidence of these practices can

contribute to understanding optimization, cultivation, and modification of aquatic 
environments on a landscape level. However, some regions have received more consideration than others; the backwater wetlands of the Lower Columbia are minimally studied. This neglect is pertinent, as intentional modifications to the landscape that optimize resources, such as the construction of fish traps, clam gardens, and even agricultural terraces or levees, affect how the landscape is interpreted. Land use can have a cascading effect on the ecosystem, creating an interconnected anthropogenic environment that is best understood as a system, rather than individual components.

The lower reaches of the Columbia River offer an opportunity to examine inland practices of aquatic resource optimization, cultivation, and landscape modification and the ways in which they influence our understanding of local subsistence, economy, diet, and technologies of inland backwater ecosystems. The Lower Columbia is particularly useful in this research, with its extensive aquatic landscape, complex ecosystem, and long history of use, both Indigenous and Euro-American (Ames and Maschner 1999; Butler and Martin 2013; Boyd et al. 2013; Darby 1996; Pettigrew 1977; Saleeby 1983; Trieu Gahr 2013).

Archaeological and ethnohistoric records highlight the importance of aquatic plants like wapato (Sagittaria latifolia), and mammals that inhabit wetland environments, such as beaver (Castor canadensis) and muskrat (Ondatra zibethicus) (Ames et al. 1999; Darby 1996; Lyman 1994). Ichthyofaunal remains of freshwater fish (e.g. Catostomidae and Cyprinidae) are also prominent in regional archaeological site assemblages, often outnumbering anadromous salmonid remains (Butler and Martin 2013; Saleeby 1983). This abundance is interesting, as very few mass capture structures have been identified in 
association with backwater environments, creating questions as to how these fish were harvested. Historically, the waterways of the Lower Columbia have also played a pivotal role in the development of Euro-American agriculture and commercial fisheries of the region. This raises questions as to how wetland resources in the region were used and potentially optimized in the broader context of the backwater ecosystem, and how this ecosystem has been modified by humans, both in the precontact Indigenous northwest and the early historic and contact era.

An anthropogenic stake alignment feature located on Sauvie Island in a backwater lake offers a starting place to examine these questions (Figure 1, Figure 2). The feature was first identified by local landowner and avocational archaeologist Dennis Torresdal in 2012. Mr. Torresdal contacted Portland State University archaeologist Virginia Butler to report a possible archaeological site in Virginia Lake within the Oregon State Parks Wapato Access Greenway on Sauvie Island. Dr. Butler, accompanied by archaeologists Sarah Campbell, Ken Ames, and Madonna Moss, inspected the site and determined the feature was anthropogenic in nature (Virginia Butler and Dennis Torresdal, pers. comm. 2016). However, no formal testing or survey was conducted during this visit, and the site was not officially recorded. The feature consists of a paired alignment of wooden stakes that extends approximately $60 \mathrm{~m}$ from the lake edge into the wetland. Prior to $20^{\text {th }}$ century levee construction for agricultural purposes, the lake was part of a frequently flooded landscape and interconnected productive wetland on the island (GLO 1854; USGS 1915). The site is inundated with water most of the year and is only accessible in the late summer/early fall. 


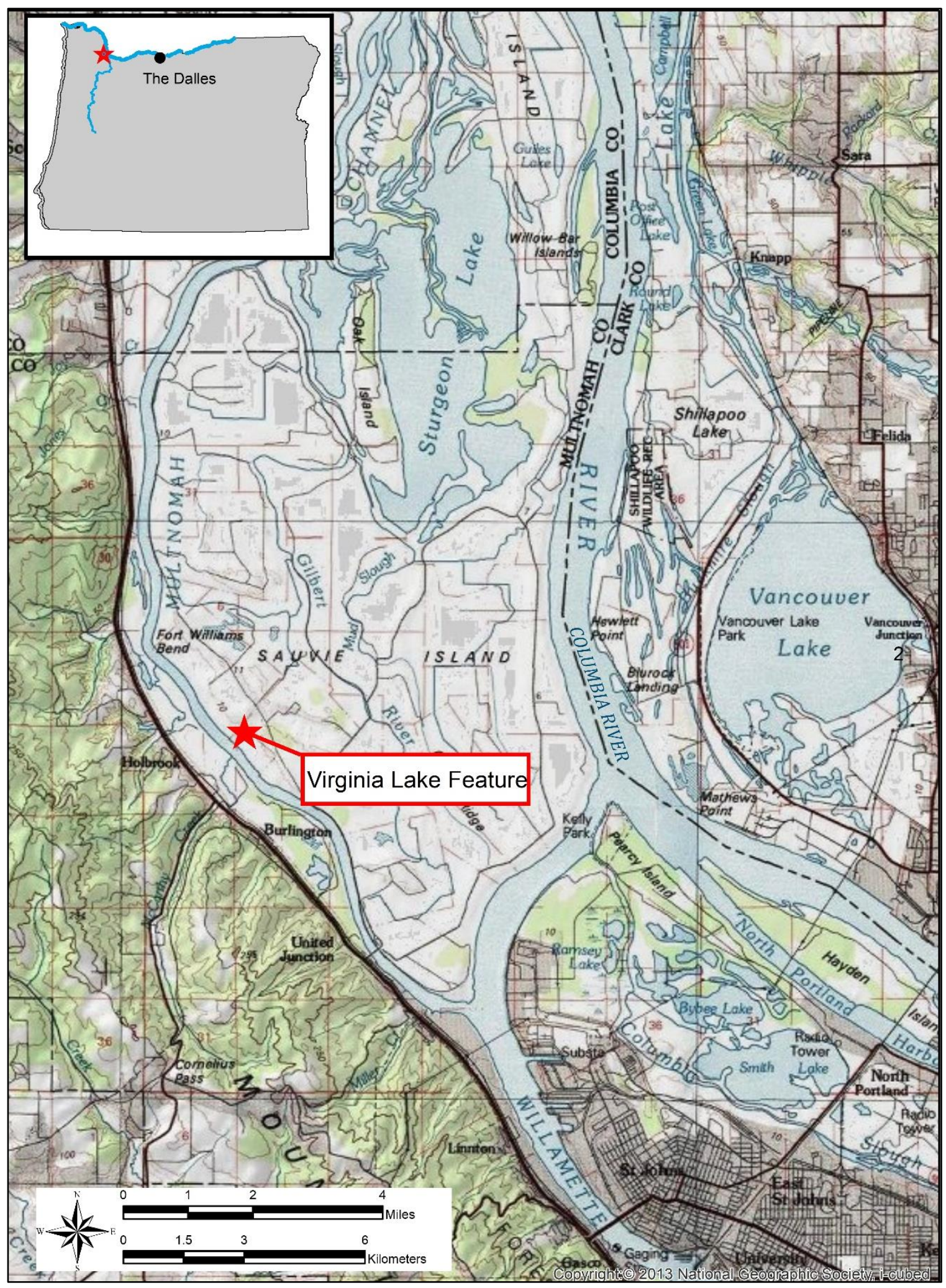

Figure 1. Project Location Map. Insert displays the Willamette River and the Lower Columbia River from The Dalles to the Pacific Ocean. 


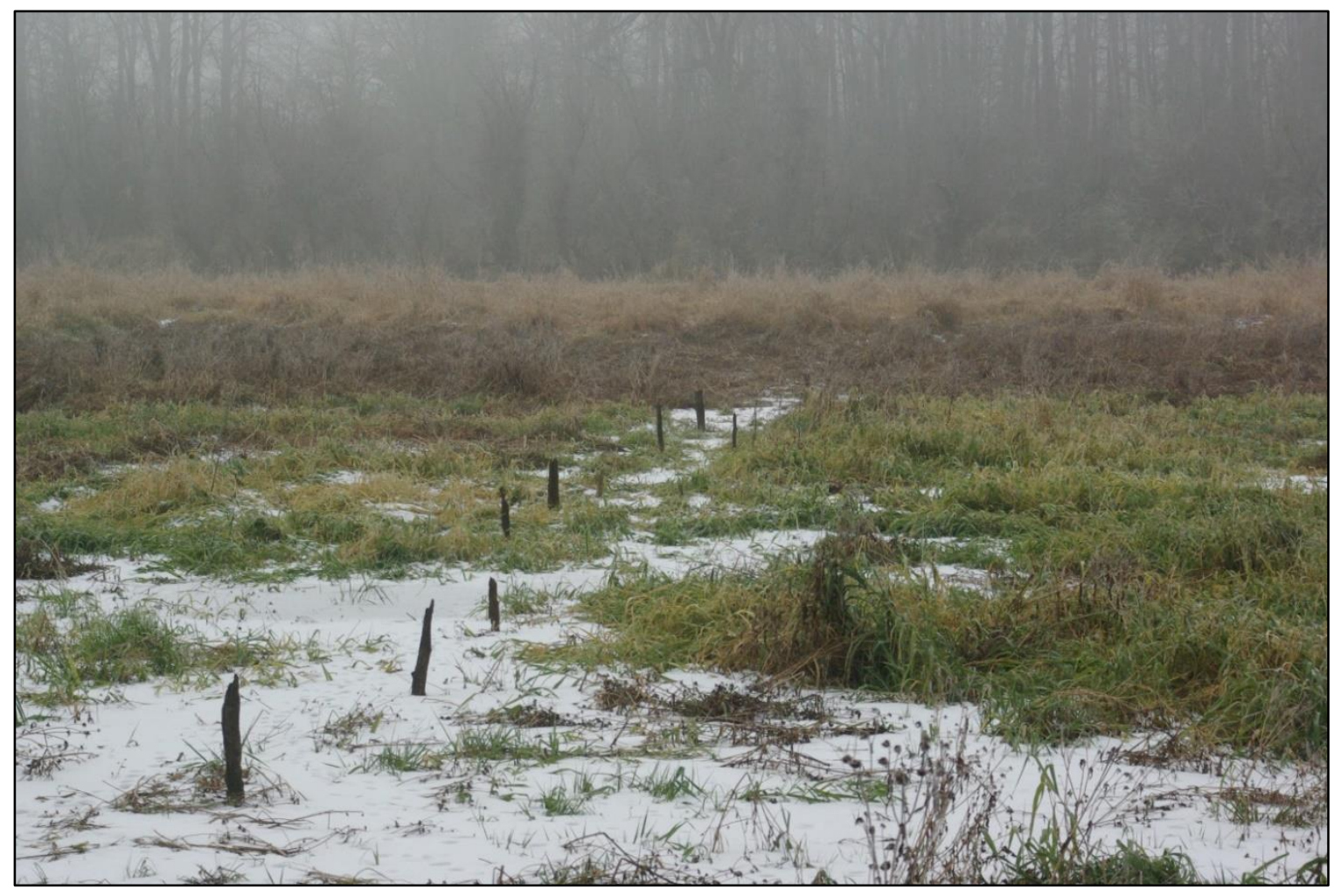

Figure 2. Virginia Lake feature during a rare winter exposure, view east. Image courtesy of Dennis Torresdal.

The stake alignment, especially in a backwater context, is an uncommon archaeological feature in the regional record and presents many questions, and possibilities in age, function, and cultural affiliation. It is possible that the alignment represents an Indigenous system for storage or resource acquisition, such as a fish weir, akin to the one in Vancouver Lake (Wessen 1983) (see section 4.4 below for discussion of the Vancouver Lake weir). It could also represent a Euro-American feature or boundary line relating to ranching, hunting, or transportation.

The goal of my study is to investigate the stake alignment in order to address the questions about its age and origins. I defined my study area as the Virginia Lake basin. My work documents the stake alignment feature and creates a methodological template 
for evaluating other anthropogenic stake sites in the future. I evaluate hypotheses related to its age, function, and cultural affiliation, and place it within a broader context of wetland use, and human ecosystem engineering. To accomplish this I conducted historic research, and performed fieldwork, including detailed mapping, survey, subsurface testing, and stake sampling. I then created a protocol to analyze tool marks on the wood stakes collected during subsurface test excavations. I analyzed the lake and channel formation history to better understand the function of the feature and the lake's environmental history. I submitted samples from the feature for Accelerator Mass Spectrometry (AMS) dating and macrobotanical identification. I conducted regional comparative analysis, comparing my results to previously published data from three wetland archaeological sites that contain anthropogenic stakes in the Lower Columbia, and used Niche Construction Theory and Historical Ecology to inform broader relationships between people, wetland use and modification through time. As well as a better understanding of the Virginia Lake feature, my project also generated a template for any study that seeks to assess features of this kind, especially in lieu of known ethnohistoric or ethnographic links, as is the case here. Such a methodological system could facilitate future identification and analysis of similar features.

This thesis is organized into five chapters. In Chapter 2, I discuss the background that informs my study, and situate the feature within the physical, historical, and archaeological landscape. I also outline the theory that guided my project. This background explicates what is previously known about the landscape and archaeology of Sauvie Island, as well as the culture of the Indigenous Chinookan people and early EuroAmerican settlers in the region. I also explore previous research on human landscape 
modification, and the current theoretical underpinnings used to study such modification, which will serve as the theoretical framework for my thesis. At the end of Chapter 2, I outline the questions and hypotheses that guide my methodology and the tasks I propose for addressing them. In Chapter 3, I explain my methods, materials, and research design in detail. In Chapter 4, I present the results of my archival research, fieldwork, lab analysis, and inter-site comparison. Finally, in Chapter 5, I review my initial hypotheses related to the feature, consider the values of my study, highlight the limitations of the project. 


\section{Chapter 2: Background}

In this chapter I discuss current knowledge of the history of the Lower Columbia. I address research relating to the formation of the region and its environment, the peoples who inhabit the Lower Columbia both Indigenous and settler, and how they are known to have utilized the wetland environments. I also discuss the theoretical framework I use to inform my hypotheses and evaluate my research, and I outline my research questions and associated hypotheses.

\subsection{Lower Columbia Environmental History}

The study area is located on Sauvie Island (Figure 1), within the Portland Basin of the Lower Columbia. The Lower Columbia is generally described as including the Columbia River's final approximately $314 \mathrm{~km}$ (195 miles) stretch between the western edge of the Columbia Plateau at The Dalles and where it meets the Pacific Ocean. The Lower Columbia is considered a subregion of the Northwest Coast culture region (Ames and Shepard 2019; Cannon 2015; Newman 1991; Sobel et al. 2013). After running through the Columbia Gorge, the river turns north through the Portland Basin, eventually flowing westward through the Coast Range toward its final outlet (Sobel et al. 2013). After the last glacial maximum, a series of floods inundated the Columbia Plateau and travelled down the Columbia River and into the Willamette Valley, between approximately $19,015 \pm 165{ }^{14} \mathrm{C}$ yr B.P. and 13,695 $\pm 95{ }^{14} \mathrm{C}$ yr B.P. (Benito and O'Connor 2003; O'Connor et al. 2001). These floods transformed the landscape, burying much of the lowland areas in fine-grained alluvial sediment, as well as depositing a number of glacial erratics (O’Connor et al. 2001). 
Sauvie Island is located approximately $140 \mathrm{~km}$ (86 miles) upriver from the mouth of the Columbia, at the river's confluence with the Willamette (Figure 1). The island is bounded by the Multnomah Channel and Columbia River on the western and eastern shores, respectively (Figure 1). It was formed approximately 2,500 years ago when sediment deposition and natural channel migration of the Columbia built out the landform (O'Connor 2012). Around this same period, sea level rise likely diverted the Willamette River, cutting Sauvie Island off from the mainland at its southern end (O'Connor 2012).

The flow and levels of water in this portion of the river are also influenced by tidal patterns, which can affect the Columbia all the way to the Bonneville Dam in times of low flow (Cannon 2015; Jay et al. 2015). During higher flows, the river is less susceptible to tidal influence. Near the U.S. Geological Service (USGS) monitoring station at Vancouver, Washington, across the Columbia River from Sauvie Island, the river level can vary up to $1 \mathrm{~m}$ in height as a direct result of measured tidal fluctuations (Cannon 2015).

Historically, spring floods, often referred to as "freshets," were the primary catalyst for geomorphic change and heavily influenced how and when the Lower Columbian landscape was utilized, especially Sauvie Island (Cannon 2015; Spencer 1950). Prior to extensive $20^{\text {th }}$ century development, which altered the flood intensity and regime, regional wetlands were seasonally flooded, productive environments. Estimates drawn from figures published from the U.S. Army Corps of Engineers (USACE) indicate that prior to levee construction, the island lowlands flooded upwards of 43 times between 1858 and 1930 (Saleeby 1983). However, this watery, often flooded landscape did not fit 
with Euro-American agricultural practices and cattle ranching. As a result, these wetlands were drained, levees were built around the island, and dams were constructed along the Columbia River, reducing the seasonal flood height (Cannon 2015; Spencer 1950). "Virgin" pre-dam flow estimates of the Columbia indicate that a combination of extensive infrastructure, such as dam and levee construction, and increasing aridity due to climate change, have reduced the average amount of water entering the Lower River estuary from the interior by approximately 15\% (Cannon 2015; Naik and Jay 2005). Additionally, the infrastructure, much of which has been built for irrigation and flood control, changed the timing and intensity of runoff, lessening the variation in highs and lows, and reducing the intensity of the seasonal freshets (Cannon 2015; Naik and Jay 2005).

The first major dam built on the lower reaches of the Columbia River was the Bonneville Dam. The dam was constructed by the USACE between 1933 and 1938 to generate hydroelectric power, and was the first of many steps towards increasing the navigability of the Columbia and controlling its seasonal floods (Willingham 2018). Following the Bonneville Dam, the USACE began construction on The Dalles Dam in 1952 (Binus 2005). By 1957 the dam was completed, raising the level of Columbia River and drowning several stretches of rapids, including "Celilo Falls," the location of some of the most productive salmon fisheries in the Pacific Northwest (Binus 2005).

The dams did more than radically change the landscape of fishing on the Columbia; they also changed the river's natural flow and flood patterns. The dams increased navigability by submerging rapids (Willingham 2018). As mentioned above, 
the installation of the dams also radically decreased the seasonal flooding of the Columbia. The reduction in seasonal flood height and duration impacted the dynamism of the Columbia floodplain, decreasing sediment deposition and contributing to a reduction in wetlands.

\section{$\underline{\text { Wetlands }}$}

A wetland is defined by Cole (1984:1) as "any area of land covered by water for part of each year, or of each day, or which has been drowned by water at any time in its existence." As Cole's expansive definition implies, wetland ecosystems are common and abundant around the world, encompassing estuaries, swamps, and floodplains, among many other environments. Wetlands are also highly productive, producing between 8,800 and 9,600 kilocalories of energy per square meter per year (Ames et al. 2017; Miller and Spoolman 2009) and supporting innumerable resources. These environments are intrinsically connected to human history through time, providing resources and spurring adaptations and cultural change (Bernick 1998; Coles 1984).

Wetlands are common within the Lower Columbia due in part to the river's extensive floodplain. Prior to changes linked to Euro-American agriculture and dam construction, these wetlands were even more prevalent. Located in the Lower Columbia, Sauvie Island, the location of this study, is a 15-mile-long island made up of a mosaic of land and lakes (Spencer 1950). Before the damming of the Columbia and building of levees around the Island, Sauvie boasted more than 79 named lakes (Darby 1996). In Cannon's (2015) study of anthropogenic historic and modern influences on landforms along the Lower Columbia, Sauvie Island was included in one of the areas where 
wetlands have been most heavily modified, specifically by infilling or draining for agricultural purposes. One of the remaining wetlands on Sauvie Island is Virginia Lake, located on the southwestern side of the Island close to Multnomah Channel. The lake is a relatively flat riparian area within the floodplain of the Willamette and Columbia Rivers.

\subsection{Cultural Context}

\section{The Lower Columbia in Ethnography and Ethnohistory}

The Indigenous people who lived along the shores of the Lower Columbia, are often referred to as Chinookan peoples, named for the most prominent language family spoken in the region. While Chinookan-speaking peoples primarily occupied the lower river year-round, the region was an epicenter of trade and abundance, attracting many other groups who came to the region for trade, cultural gatherings, and to acquire resources seasonally (Ellis 2013; Hajda 2013). Chinookan peoples shared many traits and patterns with other cultural groups of the Northwest Coast culture area, such as the practice of social stratification, complex seasonal mobility patterns, and systems of ownership and prestige, while still maintaining differences in specific cultural practices such as art and house construction (Ames and Maschner 1999; Ames 1994; Boyd et al. 2013). Chinookan people, like many Northwest Coast Indigenous peoples, were adapted to and heavily used, the intricate system of waterways, creating and using boating technologies, acquiring aquatic resources, and engaging in complex systems of longdistance trade (Ames 1992, 1994, 2002; Butler and Martin 2013; Darby 1996; Hajda and Sobel 2013). These technologies and adaptations factored heavily into resource use in the region. 
There were numerous villages in the Lower Columbia at and prior to EuroAmerican contact, many of which were on Sauvie Island (Figure 3). It is thought that Sauvie Island served as an epicenter for trade in the Lower Columbia prior to EuroAmerican contact, and the area supported dense population levels that would likely have put a premium on landscape modification and resource optimization in the region (Boyd et al. 2013; Boyd and Hajda 1987; Moulton 1991). This abundance of resources and dense population likely permitted the growth of the complex socio-political systems and organizations for which the region is known (Hajda 2013).

Ethnographic evidence suggests that the largest social unit in the Lower Columbia was generally the village, which comprised one or more households, and maintained links to other villages and households through kinship ties (Hajda 2013; Ray 1938). There was marked social and economic stratification within Chinookan villages as a whole; the division of labor between men and women, and between free people and slaves is documented (Ames 1994; Hajda 2013). The Chinook occupied permanent villages in the colder months, which were often located near important resources, such as those documented on Sauvie Island (Ames 1994; Boyd and Hajda 1987). Villages could include a single house, or several large plankhouse style dwellings. In spring and warmer months, some family groups would leave the villages to move closer to seasonally available resources, living a more nomadic existence. However, it is likely that some groups remained in permanent villages year-round (Hajda 2013; Hajda and Sobel 2013; Saleeby 1983). 


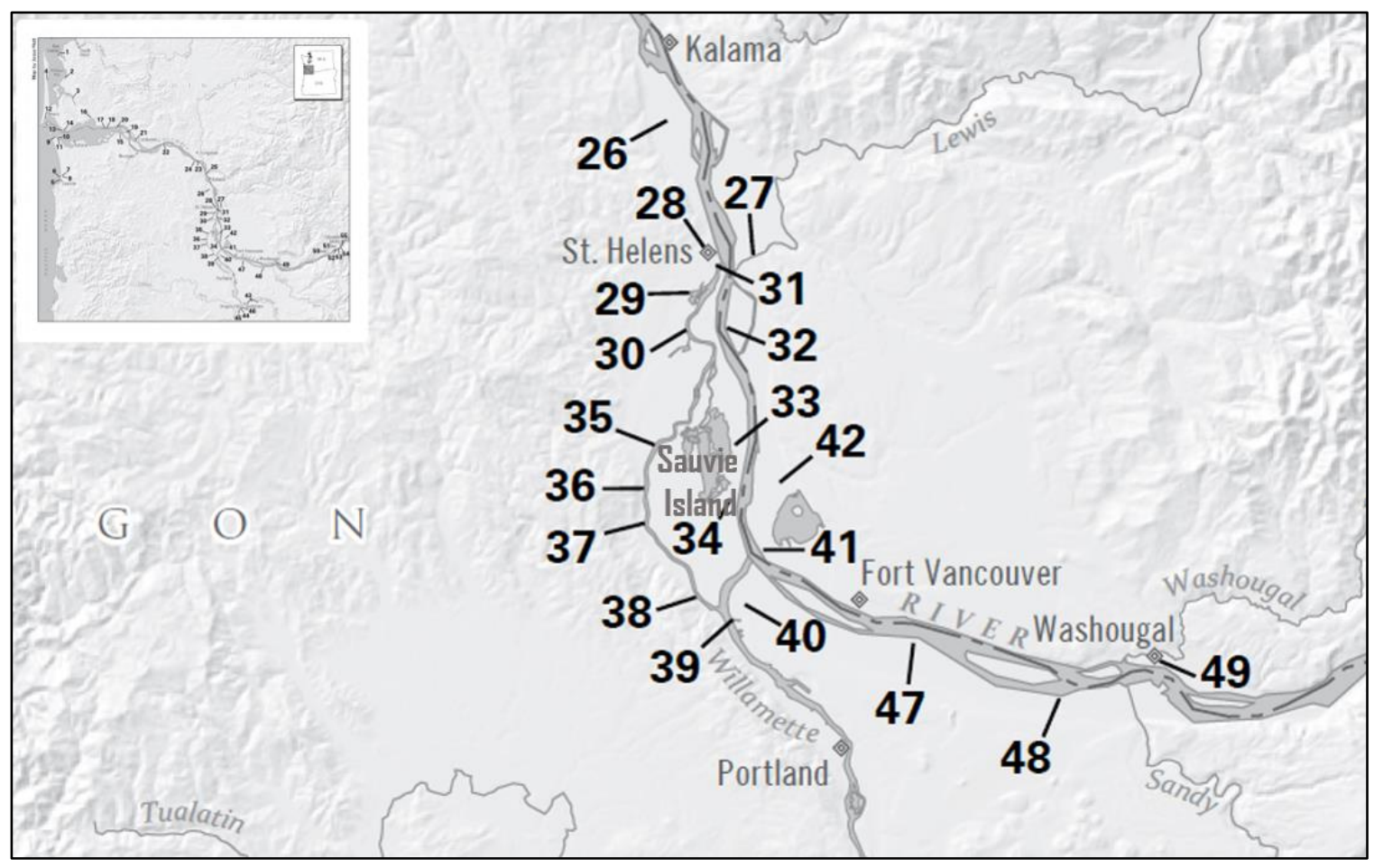

Figure 3: Sauvie Island and other village locations based on early $19^{\text {th }}$ century accounts, see Zenk et al. 2016 for corresponding village names. Map by Jesse Nett, originally published in Henry Zenk, Yvonne Hajda, and Robert Boyd, "Chinookan Peoples of the Lower Columbia," Oregon Historical Quarterly, 117:1 (Spring 2016): 6-37, used here by permission.

Far reaching trade networks were woven into the fabric of life within the Lower Columbia. These networks, enabled by the waterways that traverse every corner of the region, extended to the coast and east past the Columbia Plateau (Hajda and Sobel 2013). By the contact era, ethnohistoric accounts suggest that control of these trade networks had become a source of prestige, integrating new sources of trade items and a changing world into existing systems of ownership and social division (Hajda and Sobel 2013).

The first documented face to face contact between Indigenous peoples of the Lower Columbia and Euro-Americans occurred in 1792, when Captain Robert Gray entered the mouth of the Columbia (Lang 2013). This year also marked the first time 
Euro-Americans set foot on Sauvie Island. William R. Broughton, who sailed up the Columbia River with Captain Vancouver's exploring expedition under the orders of the British Royal Navy, recorded approaching a point of land at the confluence of the Columbia River and what is now called Multnomah Channel, likely the southern end of Sauvie Island (Lang 2013; Spencer 1950). Broughton camped along the east side of the island one night on the expedition. He noted in his log that he was met on the shore by approximately 150 Chinookan people (Spencer 1950). Thirteen years later, Americans Meriwether Lewis and William Clark visited Sauvie Island during their exploration west (Moulton 1991; Spencer 1950). Lewis and Clark, having heard of the island from Native American informants, called it "Wappato Island", named for wapato, the edible aquatic tuber that grew in abundance there (Moulton 1991; Spencer 1950).

After Euro-American contact, Indigenous people were affected by violence, land theft, and most prominently, a range of exotic diseases that swept through Chinookan communities (Boyd 2013). A malaria epidemic devastated Indigenous people of the region in the 1830s, inducing a population decline estimated at upwards of $90 \%$ (Boyd 2013; Spencer 1950; Taylor and Hoaglin 1962). As a result of this, and earlier epidemics, ethnohistoric accounts of Lower Columbian Indigenous people are scarcer after 1830. Later ethnographic accounts describe lifeways and land use practices that are likely much changed from those of precontact conditions (Ray 1938).

\section{$\underline{\text { Postcontact History of Sauvie Island }}$}

The first Euro-American colonist to settle on Sauvie Island was a fur trader by the name of Nathaniel Wyeth. Wyeth had started a small fur and fish trading business and 
was quietly competing with the nearby British owned Hudson Bay Company (HBC) (Spencer 1950). In 1834 Wyeth constructed Fort William on the land that is located less than $1.6 \mathrm{~km}$ (1 mile) north of Virginia Lake. However, Wyeth was plagued by bad luck and intense competition with the HBC. By the fall of 1835, Fort William had failed (Eaton 1935; Spencer 1950).

In 1838 the HBC started a dairy at the same location as Wyeth's fort (Spencer 1950). HBC assigned French Canadian Laurent Sauvé, for whom the island would eventually be named, to run the daily operations (Spencer 1950). The dairy was to supply butter to the Russians in exchange for furs for the HBC, however, supply rarely met demand (Spencer 1950). Sauvé retired in 1844 and was replaced by James and Isabelle Logie. Isabelle had received some medical training before coming to Sauvie Island and was known to minister to the sick, including Indigenous people on the island, with which the Logies appear to have had an ongoing relationship (Spencer 1950). This is indicative of the complicated and ongoing interaction between settlers and the Indigenous people who continued to reside in the Lower Columbia, after Euro-American colonization. In addition to individual relationships, Indigenous communities were interacting regularly with the HBC, providing much needed labor, and engaging in and facilitating complex systems trade (Deur 2012).

In 1846 all land south of the $49^{\text {th }}$ parallel became American territory, and by 1849, the HBC had withdrawn to Canada (Cannif 1981; Spencer 1950). After the withdrawal of the HBC, Euro-American settlement on Sauvie Island was spurred on by the passing of the Donation Land Law, which permitted Euro-American settlers to claim 
acreage on unsurveyed lands until its expiration in 1855 (Robbins 1997; Spencer 1950). The land which borders Virginia Lake to the north eventually became part of the Logie Donation Land Claim (DLC 49), the Logie's having stayed on the Island after the withdrawal of the HBC. Theirs was the second claim filed on the Island (Spencer 1950). The land to the east of the lake was claimed by Jacob Cline in 1845 (DLC 48), who was granted the first land claim on the island (Spencer 1950; GLO 1862). However, neither claim encompasses the lake itself.

Despite an increase in Euro-American settlement following the DLC era, the island was still isolated. Without roads, access to the mainland was limited to boat, and seasonal floods inundated most of the island every spring. Most residents raised cattle, either for dairy or beef, grazing their animals on the island's many meadows and housing them in raised barns or ferrying them off the island during the seasonal floods (Spencer 1950).

Following the Flood Control Act of 1936, The USACE began building "Big Dike" on Sauvie Island in 1938 and by 1941 construction had finished, radically changing the landscape. With much of the seasonal flooding abated, roads were graded and rocked, and agriculture expanded. In 1949 a bridge was constructed spanning the Multnomah Channel, connecting the island community to the mainland, and ending the tradition of isolation (Spencer 1950).

Since the DLC era, the land surrounding Virginia Lake has passed through several owners. It was used for a variety of mixed agricultural, logging, and residential purposes until 1973 when the Lake and surrounding land was purchased by Oregon State Parks 
from individual private owners and the Kerry Log and Rafting Company (Oregon State Archive 1973:WD 47952, 47710,47709,47703,47933). Oregon State Parks later designated the land as a public greenway.

\section{$\underline{\text { Lower Columbia Archaeology }}$}

Most professional archaeological work that has taken place in the Lower Columbia region, and more specifically, Sauvie Island occurred between the 1970's and present and focused on the precontact era (Croes et al. 2009c; Pettigrew 1977; Pettigrew and Lebow 1987; Saleeby 1983). The earliest professional archaeological work on Sauvie Island was led by Richard Pettigrew (1977), whose goal was to develop a culture history of the region. Pettigrew worked with amateur collectors and local land owners to test a series of sites that spanned 2600 years of Indigenous land use on the island and greater Lower Columbia (Pettigrew 1981, 1977). Focused on distinct, temporally diagnostic artifact types, Pettigrew built a cultural chronology for the region (Pettigrew 1977). Thanks in large part to the work of Pettigrew, there is a well-defined chronological framework of the last 2500 years on Sauvie Island, and more broadly, the Portland Basin. The scarcity of older sites is the result of geomorphic processes, as the island itself is thought to have formed roughly 2500 years ago (O’Connor 2012).

Saleeby (1983) was the first archaeologist to document the prominence of wetland animal use in the region, through the study of faunal remains recovered by Pettigrew's excavations. More recent work by Dale Croes and colleagues on the Sunken Village site (35MU4) documented acorn use and perishable artifacts. This extensive wet site is known as an acorn leaching and processing site. It is characterized by a series of 
baskets partially buried in the intertidal zone on the southwest edge of Sauvie Island. Large scale excavations conducted by Dr. Kenneth Ames and colleagues at the Meier (35C05) and Cathlapotle (45CL1) village sites, located near Scappoose, Oregon on the mainland adjacent to Sauvie Island, and across the Columbia near Ridgefield, Washington respectively, have explored a range of questions about social complexity, trade, and resource use (Ames et al. 1999; Butler and Martin 2013; Croes et al. 2009c; Lyman 2003; Saleeby 1983). However, none of these previous investigations have fully considered the ways in which people modified backwater landscapes. Work outside of these large-scale academic excavations has been almost entirely contract work (e.g. Hibbs and Ellis 1988; Pettigrew et al. 2005; Wessen 1983).

\section{$\underline{\text { Wet Sites }}$}

As previously discussed, wetlands are highly productive landscapes, connected to human activity and occupation through time, providing abundant resources and spurring adaptation and development of novel technologies and techniques. Sometimes, these resources, technologies, and cultural materials preserve in the anaerobic environments afforded by wetlands, creating what is known as "wet sites" (Bernick 1998; Cole 1984). This preservation, promoted by lack of oxygen and perennial water saturation preserves otherwise perishable material such as wood, basketry, and bone, and provides a unique glimpse into human history (Bernick 1998). These sites also present unique challenges to identification, excavation, and preservation (Bernick 1998; Byram 2002; Croes 1976, 2001; Kaye et al. 2000). Because waterlogged artifacts often change shape or disintegrate 
as they are exposed to air, they require immediate conservation steps and have unique storage requirements (Bernick 1998; Coles 1984; Werz and Seemann 1993).

Due in part to its alluvial depositional environment and frequent flooding, Sauvie Island can potentially support wet sites, an example of which is the aforementioned "Sunken Village" (35MU4). This wet site was first recorded in 1973, and subsequently re-assessed in 2006-2007 (Croes et al. 2009c, 2009a; Pettigrew 1973; Pettigrew and Lebow 1987). Virginia Lake provides a similar capacity for wet sites, but a different environment from Sunken Village. While frequently inundated with water, in the late summer and early fall the water level in the lake drops, drying and exposing potentially perishable material to air for several weeks at a time (Dennis Torresdal personal communication 2017).

\section{$\underline{\text { Wetland Cultural Constructions }}$}

Wet sites such as Sunken Village are just one example of what I will refer to here as "wetland cultural constructions". These constructions are intentional anthropogenic modifications to wetland landscapes that optimize resources or engineer the environment for human use. They span continents and are observed in both archaeological sites and historical documents. These constructions elucidate intentional, active processes, dispelling the notion that people, especially Indigenous people, passively utilized natural abundance (Caldwell et al. 2012; Campbell and Butler 2010b; Grier 2014). Understanding these modifications as cultural constructions also emphasizes the environments and humans interactions therein as not just an ecological, but also social phenomena (Grier 2014). 
Examples include complex wetland agricultural systems (Costa-Pierce 1987; Cannon 2015; Hoffmann et al. 2016; Kirch 1982; McKey et al. 2010, 2016), extensive inter-tidal systems for fisheries procurement (Caldwell et al. 2012; Deur et al. 2015), and alterations of the landform itself, such as the expansion and creation of islands and spits (Grier 2014; Sampson et al. 1985). These systems use small and large scale modifications that have cascading effects that increase resource abundance, optimize access, and transform landscapes and ecosystems, potentially increasing habitability (Grier 2014; Sampson 1985).

Constructions need not be of massive scale. Single features, such as the Virginia Lake stake alignment also fall into this concept of cultural construction. An example of this are fish weirs, such as those documented by Byram (2002), Caldwell (2012), Losey (2010), Schalk and Burtchard (2001), and Tveskov and Erlandson (2004) and others. Weirs are stationary structures constructed in water that act as a funnel or barrier to direct or trap fish for harvesting. These structures are wetland cultural constructions, having both modified the estuaries they occupy, optimized aquatic resource harvest, and fulfilled a cultural role. Specifically, weirs are both physical, and cultural constructs, having implications for ownership, spiritual practice, and the complex, structured, social networks required to build and maintain them (Caldwell et al. 2012; Grier 2014; Losey 2010).

Cultural constructions like weirs are not just recorded in intertidal estuaries. These structures have been observed in more inland environments both riverine (e.g. Connaway 2007) and pluvial (e.g. Wessen 1983). Connaway (2007) places weirs into three distinct 
categories based on these environments and how they function: flowing stream weirs, tidal weirs, and longshore weirs. Within these categories there exists variation in construction and design.

\subsection{Theoretical Framework}

To inform my analysis in this project, I use Niche Construction Theory (NCT) and Historical Ecology (HE), which are increasingly being used to examine human/landscape relationships. In particular I study how features, such as the Virginia Lake feature, can be understood as components in larger patterns of human ecosystem modification as human constructions that optimize resources and alter the environment to more efficiently meet human needs. As archaeology has moved toward a landscape approach, the connections between past peoples and intentional environmental optimization have become more pronounced. These modifications, while initially appearing as localized, are now being recognized as components in larger anthropogenic

ecosystems (Deur and Turner 2005; Lepofsky and Caldwell 2013; Lightfoot et al. 2013; McKey et al. 2016; Thornton et al. 2015).

NCT formed as an offshoot of Human Behavioral Ecology, which is concerned with understanding how different human behaviors are adaptive within particular environmental and social contexts (Bird and O’Connell 2006; Kelly 2013). Human Behavioral Ecology is used in archaeology to study and predict human behaviors, such as prey selection and technological use and investment. These predictions rest upon the Darwinian assumption that foragers will make decisions that optimize resource 
procurement as it relates to overall evolutionary fitness (Bird and O'Connell 2006; Kelly 1996, 2013; Lindstrom 1996).

NCT suggests that humans (and other organisms) can alter their environments to enhance their selective fitness, in effect, constructing their own niche. Beaver dams are one example of niche creation. Dam construction modifies the riparian ecosystem by creating a lake-like environment, thereby altering the transportation of water, debris, and nutrients downstream, which effects other plant and animal communities within that ecosystem. Humans also modify their environments to create niches, which in turn affects evolutionary fitness, and the entire web of life in the modified ecosystem. An example of human optimization and niche creation in the context of NCT is anthropogenic burning of oak groves. By using fire to make acorn harvest easier, Indigenous people also altered the landscape to provide better grazing habitat for deer and elk, by suppressing the density of the understory. This increases the predictability of prey location. Burning also has broader impacts by suppressing the growth of some plants, while simultaneously increasing the yield of others. In this way, human modification through burning altered not only the selective pressure surrounding acorn harvest to the advantage of Indigenous people, but multiple other plant and animal resources within the ecosystem (Mohlenhoff and Codding 2017).

Using the NCT framework, archaeologists attempt to track how people manipulate their environments to intentionally transform selective pressures, such as resource location or productivity, creating cascading impacts on entire ecosystems, with humans as catalysts (Erickson 2000; McKey et al. 2016; Mohlenhoff and Codding 2017; 
Smith 2007). In this context, some archaeologists view NCT as acknowledging human agency and intent in an otherwise Darwinian optimization model. Concepts of agency and intent can be further explored by applying HE to studies of NCT. It should be noted that for the purposes of this thesis, human ecosystem engineering is not considered a synonym for NCT, nor is it a theory. As it is used here, it is a phrase used to describe a system (see Comberti et al. 2015; McKey et al. 2010).

$\mathrm{HE}$ is a research program that uses a dialectic, holistic approach to explore human-environment interactions through time using landscapes as a unit of analysis (Armstrong et al. 2017; Balee 2006; Crumley 2007; Fitzhugh et al. 2019; Lepofsky et al. 2017). HE focuses on decision making and human agency in environmental interaction over time (Balee 2006). It can be used with an NCT framework, adding to how we understand the ways in which humans alter environments and selective pressures, by considering the variables of agency and historical contingency.

In the context of this project, I use HE to explore how human ecosystem engineering, through resource management and anthropogenic modification, shapes landscapes. HE assists with this by encouraging looking at the feature and its context across temporal scales, and using multiple methods and cross-discipline techniques in an effort to "tease out the intentional from the incidental, thus assuring that human agency is not a forgotten piece of the landscape's history" (Lepofsky et al. 2017:449). In the spirit of an historical ecological approach, I use multiple methods to piece together the history of the feature, and the landscape of which it is a part. 


\subsection{Questions and Hypotheses}

The four main questions my thesis addresses are: (1) How old is the Virginia Lake feature? (2) What is the cultural affiliation of the feature? (3) What is the probable function? (4) How does this feature relate to human ecosystem engineering in the broader wetland landscape of the Lower Columbia?

To address the first three questions, I developed multiple working hypotheses and outlined a series of tasks to evaluate them (Table 1). For example, addressing the question of age helps assess the cultural affiliation. I sought to address both questions by obtaining AMS radiocarbon dates. AMS dates provide a limiting age of the feature's construction. Understandably, knowing the age of the building materials aids in making inferences about the feature's age and cultural affiliation. A limiting age that pre-dates Euro-American contact ( 1792 AD) indicates initial Indigenous construction and could suggest continued Indigenous affiliation with the site, although later repurposing by Euro-Americans is still possible. Obtaining ages that post-date contact does not necessarily indicate Euro-American affiliation, given that Indigenous people continued to occupy the region. Determining function requires many tasks, including surveying to identify all components of the feature and accurately map them. The fourth question, concerning the relationship between the feature and a larger system of human ecosystem engineering and aquaculture is evaluated in the context of the answers to the first three questions, and through broader regional inter-site comparison. 
Table 1:List of main research questions, associated hypotheses, and outline of tasks required for evaluation.

\begin{tabular}{lc}
\hline Question 1: What is the age of the Virginia Lake feature? \\
\hline $\begin{array}{l}\text { Hypotheses } \\
\text { H1: Precontact era }\end{array}$ & Tasks \\
H2: Historic era & Metal detector survey \\
H3: Multi-component- spanning the & Modification Analysis \\
precontact and historic era. & Subsurface testing
\end{tabular}

\begin{tabular}{ll}
\hline Question 2: What is the cultural affiliation of the Virginia Lake feature? \\
\hline Hypotheses & \multicolumn{1}{c}{ Tasks } \\
H1: The feature is Indigenous & AMS Dating \\
H2: The feature is Euro-American & Metal detector survey \\
H3: The feature is multi-component & Modification analysis \\
and/or repurposed & Macrobotanical ID \\
& Pedestrian survey (ID associated features) \\
& Subsurface testing (ID associated \\
& components or artifacts) \\
\hline Question 3: What is the function of the Virginia Lake feature? \\
\hline Hypotheses & Tasks \\
H1: Fish weir & Stratigraphic analysis \\
H2: Causeway or pier & Pedestrian Survey \\
H3: Hunting platform/blind: & Metal detector survey \\
(waterfowl, muskrat, beaver, etc.) & Subsurface testing \\
H4: Post and line structure for & Inter-site comparisons \\
straightening/storing cedar planks & Collect surface elevation data \\
H5: Boundary line or fence & Accurate map/spatial data \\
H6: Multi-use & \\
\hline
\end{tabular}

Question 4: How does the feature relate to human ecosystem in the we tlands of the Lower Columbia?

$$
\text { Tasks }
$$

Inter-site comparison

Synthesize results of first three questions

and place in broader regional context 


\section{Chapter 3: Methods and Materials}

My research involved three main stages of work: (1) archival research, (2) fieldwork, and (3) lab analysis. Within these stages of work, I use multiple methodologies and techniques, which are described in detail below.

\subsection{Archival Researchand Map Review}

To evaluate the history of the study area, assess the possible historic functions of the feature, and research site-specific land use, I conducted archival research, searched the literature for stake use, and reviewed historic maps and LiDAR imaging. Archival research involved contacting the USACE and Oregon State Parks to access historic aerials, photographs, and other records.

Additionally, I reviewed documents on file at the Portland City Archives, the Oregon Historical Society, and the Multnomah Public Library, including the online archive of the historical Oregonian newspaper (1861-1987). Search terms used when searching the Oregonian included "Virginia Lake," "Wapato Access greenway," "State Parks Sauvie," "Jacob Cline Sauvie Island," and "Moar Farm." Primary records from the HBC were not consulted. The Bureau of Land Management (BLM) and USGS provided online access to historic General Land Office (GLO) and topographic maps. LiDAR imagery was provided by the Oregon Department of Geology and Mineral Industries (DOGAMI). 


\subsection{Field Work}

Fieldwork was completed over seven days between September 21 and October 1, 2018. Myself and Dr. Virginia Butler directed the work. The field crew consisted of between two and six volunteers, and included Naomi Brandenfels, Nick Guest, Anthony Hofkamp, Kaitlyn Hosken, Patrick Reed, Patrick Rennaker, Trent Skinner, Katherine Tipton, and Dennis Torresdal.

To document the feature and address my research questions, it was important to

place the feature in the broader context of the landscape. As such, site documentation was conducted at two scales: landscape-level and site-specific documentation. This was important because the feature does not exist separate from its environment, and ecosystem engineering implies the modification of an ecosystem, not a single location or feature.

The feature is located in a seasonally dry lake. Because of this, the site is subject to seasonal inundation and is only accessible during a short period of time (approximately mid-September to mid-October). Dr. Butler and I submitted a research design (Butler and North 2018) to the State Historic Preservation Office, and obtained an excavation permit (NO. AP-2538) in July of 2018 (Appendix A). We also applied for and received a scientific research permit for conducting research on State Parks land (\#30-18) (Appendix B). Fieldwork included detailed site documentation and mapping, pedestrian survey, subsurface testing, and sample collection.

Mapping was conducted using a Trimble Geo7x global positioning system (GPS) capable of sub-meter accuracy and a Trimble M3 DR series total station. During 
pedestrian survey, I utilized the GPS to record the location of features and survey transects. Subsurface test locations were also mapped using the GPS. To obtain the most precise site map possible, at the feature itself I used a Trimble M3 DR series total station to record the individual stakes and collect additional elevation points.

\section{$\underline{\text { Pedestrian Survey }}$}

To address the need for landscape-scale documentation, we conducted a pedestrian survey of the entire lake bed ( 65 acres), which had never been surveyed in its entirety (Figure 4). The systematic pedestrian survey of the project area was conducted with $15 \mathrm{~m}$ transect intervals. All encountered features were documented, photographed, and mapped.

At the stake alignment itself, a goal was to identify as many stakes as possible, including those concealed by vegetation or obscured beneath the surface. To accomplish this, we carried out intensive pedestrian survey within the feature and $10 \mathrm{~m}$ on either side (roughly north/south) of the visible stakes and approximately $30 \mathrm{~m}$ beyond the feature's western extent to a rise in the landform. This intensive survey was done shoulder to shoulder, and ground vegetation was removed as necessary to increase visibility. Documentation at this scale was also necessary to identify all possible temporally, culturally, or functionally diagnostic artifacts or components. The intensive pedestrian survey was supplemented with a Minelab Explorer SE metal detector, used to identify metal artifacts that would indicate historic affiliation. 


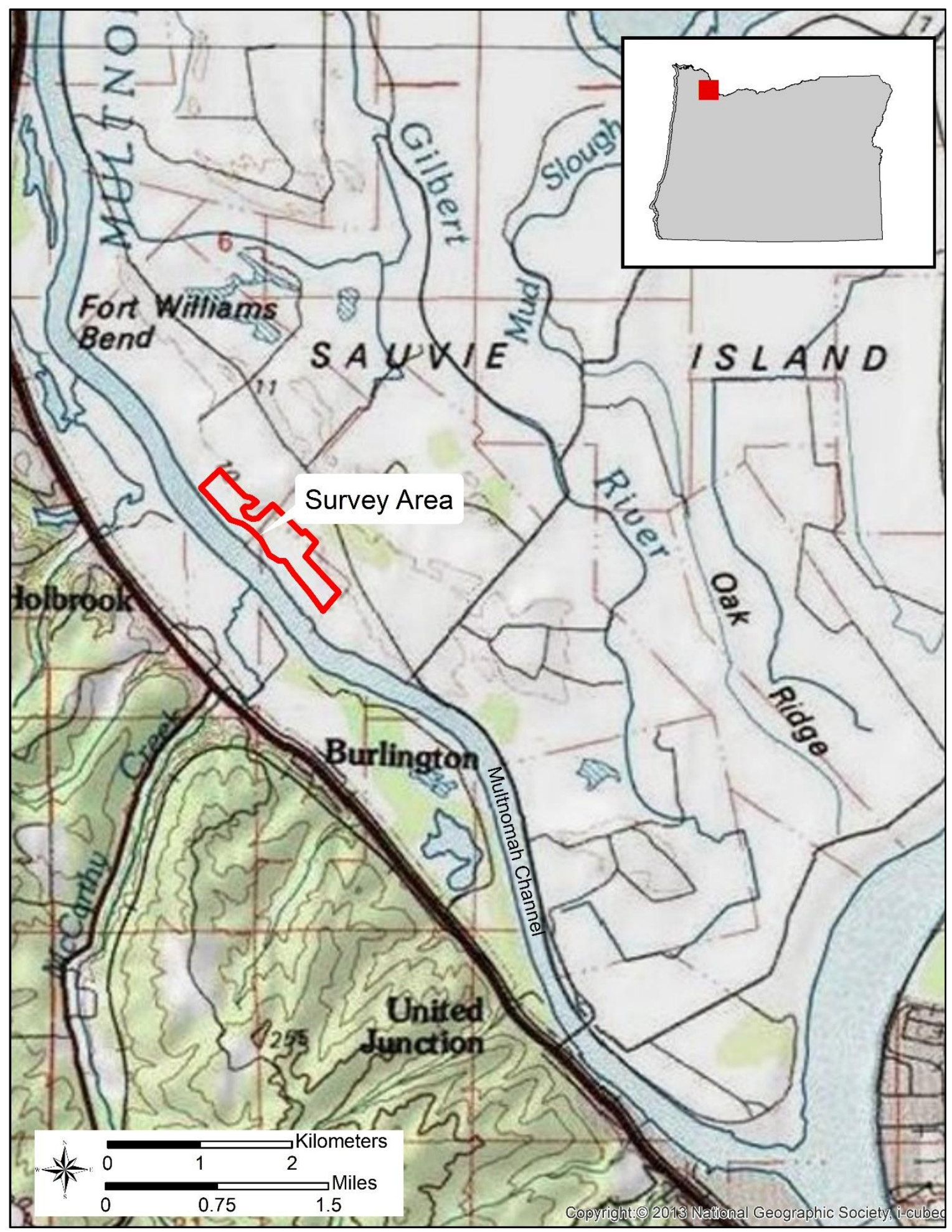

Figure 4. Survey area location map. 


\section{$\underline{\text { Feature Specific Testing and Documentation }}$}

I used subsurface testing to collect samples for AMS dating and macrobotanical identification, evaluate the extent of the site, identify buried stakes and other artifacts, explore sediment stratigraphy for use in reconstructing the landform and lake history, and to collect stakes for analysis. Two forms of subsurface testing were implemented; excavation of shovel probes (SP) and test units (TU).

In total we excavated 11 round $\operatorname{SPs}(\sim 0.5 \mathrm{~m}$ in diameter $)$ and two $1 \mathrm{~m} \mathrm{x} 0.5 \mathrm{~m}$ TUs (Figure 5). TUs were excavated using arbitrary $10 \mathrm{~cm}$ levels, measured below datum. All excavated material was screened through 1/8" (3.2 mm) hardware mesh. When sediment plasticity and moisture content interfered with the ability to push sediment through $1 / 8$ " mesh, as much material as possible was passed through the mesh and the remaining sediments were carefully troweled through by hand in the screen.

Subsurface tests were generally terminated when the water table was encountered, which precluded further excavation with a shovel or trowel. However, a long handle auger was used to facilitate deep excavation of sediments below the water table at the bottom of both TUs and two of the SPs (SP2, SP3). This excavation extended the depth of sediment visibility between 1.40 and $1.65 \mathrm{~m}$ below water table, providing additional stratigraphic information used in reconstructing landform and lake history. Four sediment samples were collected from the auger.

In addition to sediment samples collected during deep auguring, a one-quart column sample was removed from one wall of each TU. Collected sediment samples not submitted for dating were water screened through nested 1/4", 1/8" and 1/16" mesh. All 
tests were photographed, and soil descriptions and measurements recorded. Two walls of each TU were profiled. All tests were backfilled upon completion.

To characterize the feature's construction, I documented all stakes individually on a standard form. All stakes were assigned an identifying number (Figure 6). Documentation consisted of measuring the length (i.e. height) of the stake above surface, the maximum diameter at base and top, and recording the spatial location, as well as describing the general shape and condition. These measurements helped to determine the construction material (e.g. milled lumber, tree branches), layout of the feature, and degree of preservation. All stakes were documented on a standard form for consistency (Appendix E), photographed, and their spatial position mapped. 


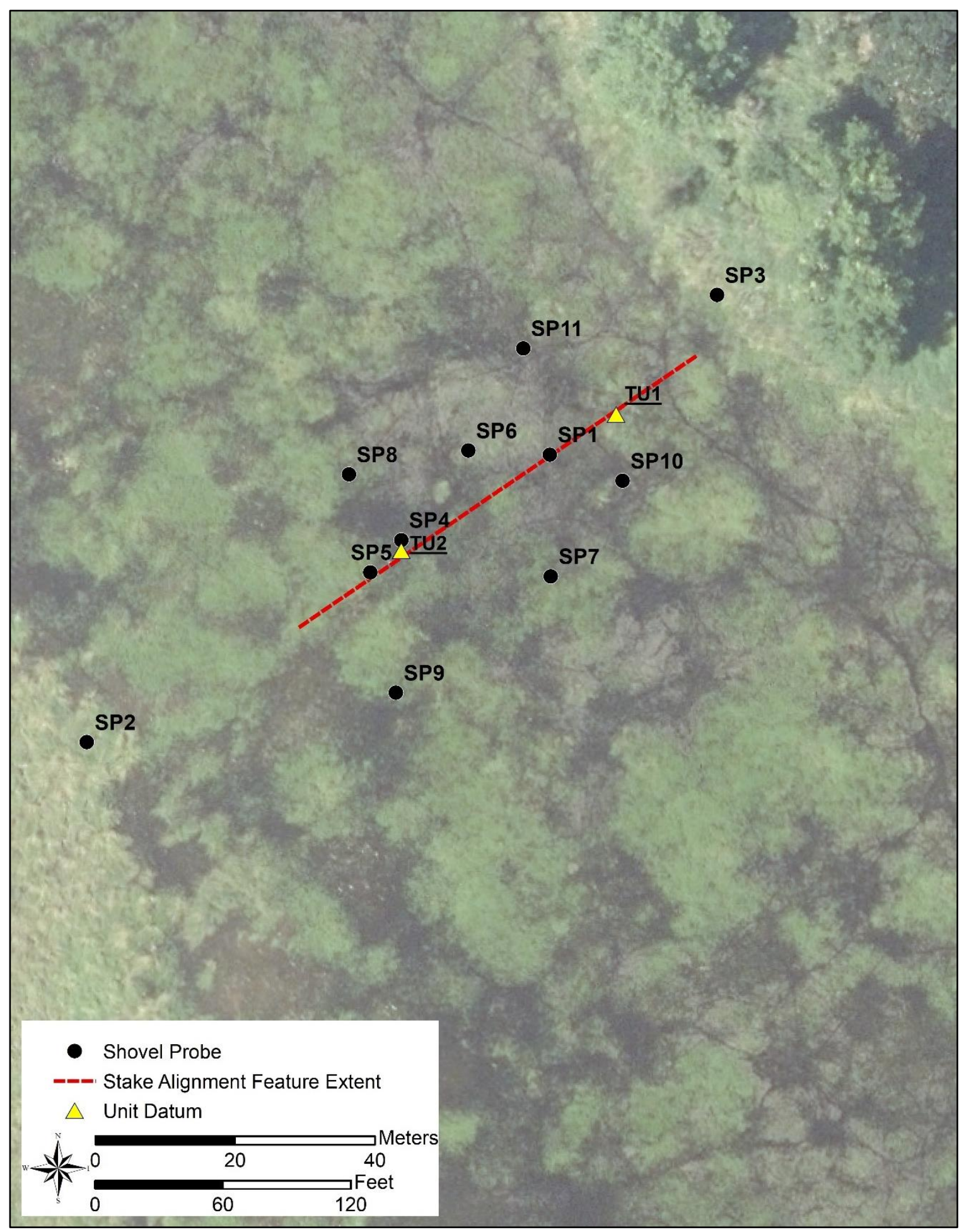

Figure 5. Subsurface testing map. 


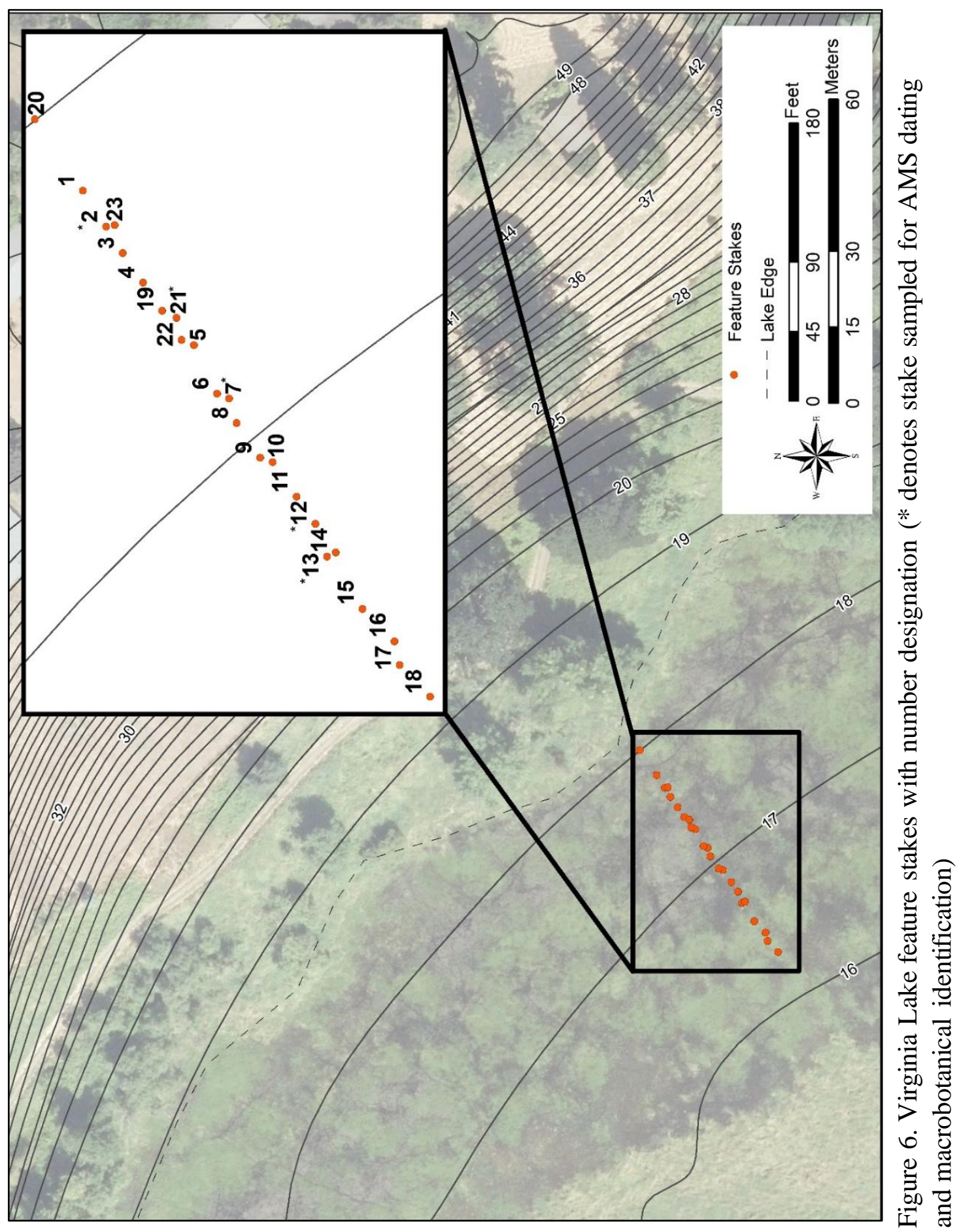




\section{Collection of Stake Samples}

To address my research questions, I needed to collect wood and soil samples from the site (Table 1). I removed two entire wooden stakes (Stake 2 and 13) and three in-situ samples from stakes left in place (Stake 7, 12, 21) (Figure 6). In total I submitted six wood samples from five stakes for AMS dating and macrobotanical analysis. I wanted to submit as many AMS dates as possible because some features, such as weirs, are known to have been rebuilt and maintained over time; it is possible the feature was re-purposed (Byram 2002; Schalk and Burtchard 2001; Losey 2010).

I chose Stakes 12, 21, and 7 for in-situ sampling. These stakes were selected from disparate areas of the feature, in varying states of preservation. This was done to ensure that I sampled as much of the feature as possible to test for variations in age or wood type, which may evidence repair or repurposing.

I removed Stakes 13 and 2 in entirety from the feature to assess the distal ends for modification. Stakes were chosen based on location and state of preservation, and removed during the controlled excavation of the TUs. Stake 13 was situated towards the middle of the feature and Stake 2 was situated toward the northeastern extent of the feature. All sampled stakes were photographed before, during, and after removal or in situ sampling, and labeled with provenience information.

\subsection{Laboratory Analysis}

Two stakes, three in-situ wood samples, and six soil samples were collected in the field and transported to Dr. Virginia Butler's Archaeology Lab at Portland State University. Laboratory analysis of the stakes consisted of toolmark modification analysis, 
AMS dating, and macrobotanical identification. Once stake samples were in the lab, they were immediately placed in a freezer. Termites were observed on the stakes during excavation, and freezing was used to prevent contaminating the lab and to stop further insect damage to the samples (Canadian Conservation Institute 1997)

The wood samples, as components of a seasonal wet site, required special care and storage. Drying needed to take place in a controlled environment. Prior to developing my protocol I conducted a literature review and consulted Susanne Rawson, professional conservator and principal at Global Artifact Preservation Services, LLC. Controlled drying was selected over long-term freeze drying or polyethylene glycol (PEG) treatment partly due to constraints of time, facilities, and funding, and because I suspected that the cyclical nature of the inundation may have left the samples less susceptible to damage while drying, having gone through cycles of wet and dry on a yearly basis.

A controlled environment was necessary to slow the rate of drying and prevent unnecessary warping and damage to the waterlogged wood. To accomplish this, I created a humidity chamber using a hard-plastic frame and plastic sheeting. A Gaylord digital thermohygrometer was placed in the chamber to monitor humidity, and distilled water was used to mist the chamber if the humidity dropped below approximately $75 \%$. The humidity was lowered approximately $10 \%$ a week for about four weeks until it reached stasis (approx. 35\%).

Despite advantages in time and cost, I encountered some issues with this drying method. The Portland State Archaeology Lab is temperature controlled but not fully climate controlled. The ambient humidity of Portland, Oregon in the winter exceeded the 
humidity required for the stakes after I began to lower the humidity in the chamber. This led to mold growth. I removed mold by gently scrubbing with a clean soft bristle brush and spraying the samples with a $90 \%$ isopropyl alcohol solution to inhibit future growth (DirectAMS personal communication 2019; Rawson personal communication 2019). To reduce humidity, I also created airflow within the chamber by partially opening it. This succeeded in lowering the humidity. However, this action lowered the humidity too quickly for manual adjustment, leading to some warping of the outer bark on the stake samples.

\section{Toolmark Modification Analysis}

I conducted toolmark modification analysis to assess whether the stakes were modified using metal or stone tools, a key line of evidence for assessing cultural affiliation and age. The analysis protocol used in my study is adapted from the protocol detailed in the Arcas Associates (1986) Meares Island study, which was originally designed for use on culturally modified trees (CMT). The Arcas (1986) study provides a detailed examination of previously recorded toolmarks on CMTs, identifies variables that can be measured, and presents a replicative experiment designed to test if specific toolmarks can be matched to traditional Nuu-chah-nulth stone, shell, or bone tools, or European metal tools based on these variables. Arcas Associates (1986) found that toolmarks on CMTs could frequently be matched to toolmarks replicated in the experiment.

I modified the protocol created by Arcas Associates (1986) by reducing the number of measurable variables from eight to seven (removing puncture marks), and 
added a new eighth variable "overall scar morphology" (Table 2). The new variable is a subjective summary of the overall morphology of the tool mark, based on images and descriptions of known toolmarks. To increase replicability, I also re-created the measurement diagrams to more accurately reflect how these variables would be measured on a stake rather than a CMT stump (Figure 7).

The toolmark modification analysis involved first identifying toolmarks on the stake, then numbering, marking, and photographing the marks, and finally applying the protocol. A given stake could have multiple tool marks. Each toolmark was recorded separately. Toolmarks were numbered only if they could be definitively given measurable boundaries, and at least two of the variables were present. My protocol (Table 2 and Figure 7) required evaluating the eight possible variables present in the mark, and then applying the results to the Arcas (1986) experimental classes (Table 5). All variables that required measurement were measured using a Mitutoyo absolute digimatic digital caliper accurate to .01 millimeters (mm). Depth measurements were gathered using a Mitutoyo .00005113735 digimatic micrometer. All measurements were taken three times and averaged. The process was repeated by a separate researcher (Dr. Virginia Butler) to test the replicability of the process. 
Table 2. Toolmark analysis variables, adapted from Arcas Associates (1986).

\begin{tabular}{|c|c|c|c|c|c|c|c|}
\hline $\begin{array}{l}\text { I. Curvature } \\
\text { of cutting } \\
\text { edge }(\mathrm{cm})\end{array}$ & $\begin{array}{l}\text { II. Shape of } \\
\text { cross section } \\
\text { Depth }\end{array}$ & $\begin{array}{l}\text { III. Length of } \\
\text { cutting edge } \\
\text { (cm) max width }\end{array}$ & $\begin{array}{l}\text { IV. Max } \\
\text { penetration } \\
\text { (cm) max } \\
\text { length }\end{array}$ & $\begin{array}{l}\text { V. } \\
\text { Neatness } \\
\text { of cut }\end{array}$ & $\begin{array}{l}\text { VI. Angle } \\
\text { of attack }\end{array}$ & $\begin{array}{l}\text { VII. Edge } \\
\text { angle (in } \\
\text { degrees) }\end{array}$ & $\begin{array}{l}\text { VIII. Overall scar } \\
\text { morphology }\end{array}$ \\
\hline Straight & Flat & $<3$ & $<2$ & Clean & Horizontal & None & Stepped-angular \\
\hline$<2$ & Concave & $\geq 3<5$ & $\geq 2<3$ & $\begin{array}{l}\text { Ragged/ } \\
\text { sheared }\end{array}$ & Vertical & $<35$ & Stepped-short, scooped \\
\hline$\geq 2<5$ & $\begin{array}{l}\text { Deeply } \\
\text { concave }\end{array}$ & $\geq 5<7$ & $\geq 3<5$ & Unknown & Oblique & $\geq 35<45$ & Undulating surface \\
\hline$\geq 5<10$ & $\begin{array}{l}\text { Very deeply } \\
\text { concave }\end{array}$ & $\geq 7$ & $\geq 5$ & & Unknown & $\geq 45<50$ & $\begin{array}{l}\text { Sharp close ridges at } \\
\text { divergent angles }\end{array}$ \\
\hline$\geq 10$ & Unknown & Unknown & Unknown & & & $\geq 50$ & $\begin{array}{l}\text { Irregular depressions in a // } \\
\text { sequence }\end{array}$ \\
\hline Unknown* & & & & & & Unknown & $\begin{array}{l}\text { narrow cut w/o wood } \\
\text { removal }\end{array}$ \\
\hline
\end{tabular}

*Unknown is used when the landmark either wasn't present or could not be measured 


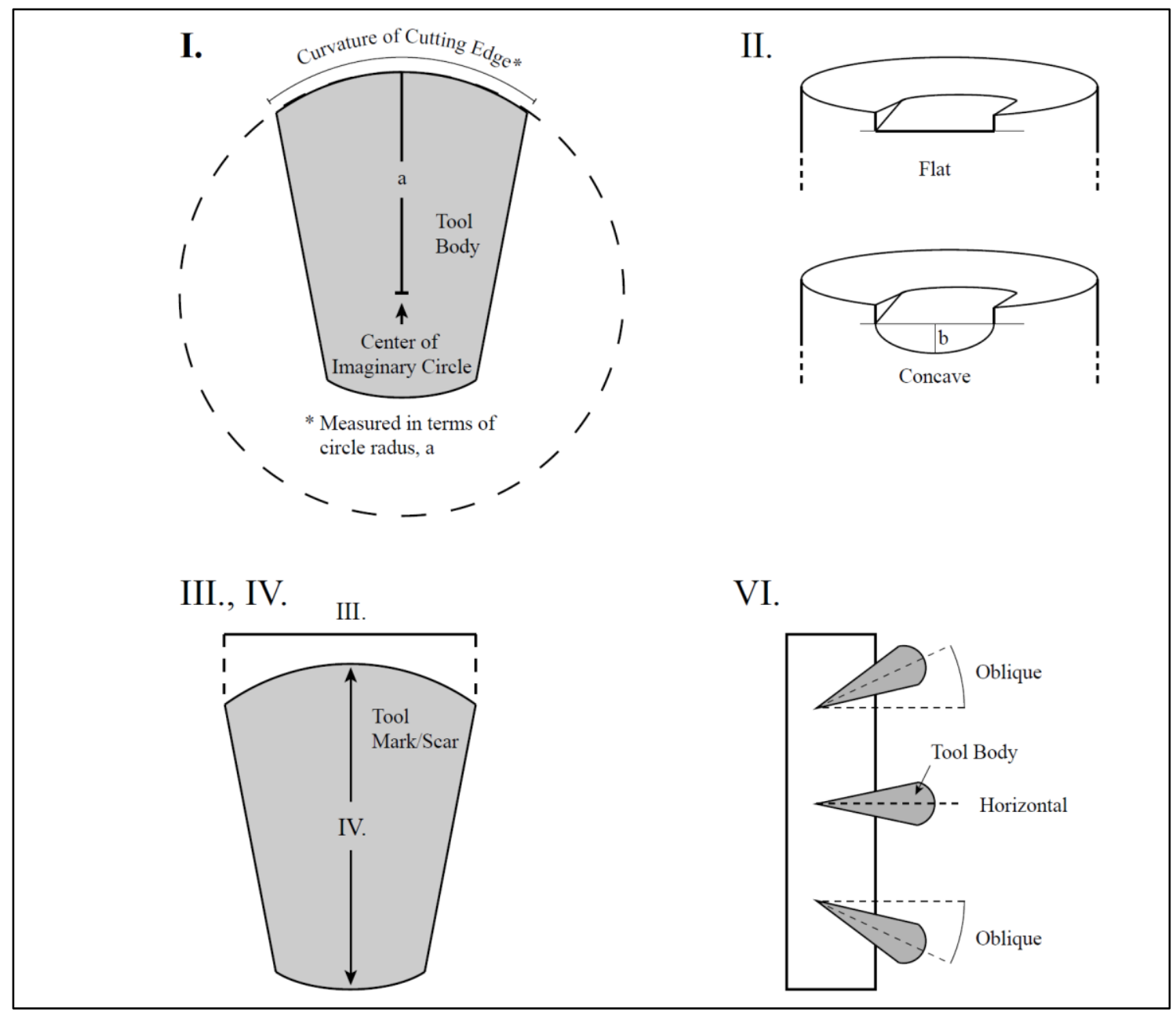

Figure 7. Toolmark modification analysis measurements diagram, image based on Arcas Associates (1986).

\section{$\underline{\text { AMS Dating }}$}

Radiocarbon dating is used to establish a limiting age in material containing residual carbon. In 1977 Accelerator Mass Spectrometry (AMS) dating was first used (Muller 1977). This new technique differs from conventional radiocarbon dating in that it directly measures the remaining amount of ${ }^{14} \mathrm{C}$ in a sample, comparing the ratio directly to the stable isotopes present, thereby decreasing the amount of material needed for dating, and increasing precision (BetaAnalytic 2019; Harris et al. 1987). 
I sent six wood samples from five stakes, and one sediment sample, to DirectAMS Labs in Bothell, Washington for dating. I used AMS dating to establish a limiting age for the feature, because it requires smaller samples, and thus is less destructive than conventional radiocarbon dating. The procedure DirectAMS uses for preparing and dating all AMS samples is available on their website (DirectAMS 2018)

Initial results from DirectAMS labs were expressed in radiocarbon years, which were calibrated into calendar years using the $\mathrm{OxCal}$ online calibration program version 4.3. Calibration is necessary to place AMS dates on a timeline, as uncalibrated radiocarbon age is directly based on the proportion of ${ }^{14} \mathrm{C}$ isotope found in the sample (Bronk Ramsey 2001, 2009), and the assumption that the atmospheric radiocarbon concentration has been stable through time, which is untrue. Calibration of radiocarbon dates accounts for fluctuating levels of radiocarbon in the atmosphere through time, giving us a true age before present.

Initial attempts at calibration produced errors. These errors are the result of the relatively young age of the samples. Samples less than 500 years old can be difficult to calibrate with certainty due to the extreme volatility of the calibration curve, which can create misleading or inaccurate calibrations (Ames and Brown 2018; Brown et al. 2019) Additional steps to increase the accuracy of the calibration consisted of taking multiple samples from the same stake (13) and using the R-combine feature, and applying a Bayesian model created by Thomas J. Brown. The R-combine feature can be used in OxCal if it is known that two samples should be statistically similar (e.g. two samples from the same object). R-combine assesses the probability distribution of both samples 
and eliminates the parts that do not overlap, creating a narrower statistical range for a calibrated date.

The model used to calibrate AMS dates in this study assumes that all samples from a single feature (in this case the stakes) are temporally related but not the same. In essence, the model favors calibrated ages that are statistically related and "cluster," and that do not produce large gaps among dated samples. This allows for more precise estimates of age range. However, the model does not force a relationship, and will display an error if there is no statistical relationship between the samples (Brown et al. 2019).

\section{$\underline{\text { AMS Dating Using Humin Fraction }}$}

Funding was available to date a sediment (peat) sample collected during deep auguring, though this task was not part of the original research design. Dating a sediment sample offered the possibility of constraining the age of Virginia Lake, and determining when it separated from the main channel. Determining lake formation history was secondary to the main goals of my thesis, but was an interesting and useful addition.

At its most basic, humin is a form of datable carbon present in sediment. AMS dating of humin fraction is often used when dating macrofossils (e.g. charcoal) is either not possible or inadvisable due to contamination (DirectAMS 2019). Pretreatment prior to this type of dating involves a procedure to remove carbonates as well as absorbed organics. The remaining alkali-insoluble humin fraction is dated.

After consultation with DirectAMS Labs I determined humin fraction dating was the best course of action for my sediment sample, as highly organic samples like peat can 
act as a filter, frequently containing contaminants of younger macrofossils unassociated with the deposit's formation. I submitted one peat sediment sample collected during deep auguring in TU2 for AMS dating using humin fraction. Peat deposits generally form in slow moving water (such as a lake), where the rate of organic accumulation exceeds the rate of decomposition, and is not enacted on by alluvial or fluvial processes that would remove them (Ming et al. 2011). Their development can indicate separation of the lake from the river channel, and formation of a more confined water body.

\section{$\underline{\text { Macrobotanical Identification }}$}

As applied in archaeology, macrobotanical identification can provide understanding of cultural affiliation and function, as different wood species are often utilized for different purposes and can be compared across sites. For example, archaeological investigations of 13 stakes from 10 intertidal fish weir sites recorded on the Oregon Coast (Byram 2002) indicated that most were constructed of western hemlock (Tsuga heterophylla). Analyses of the Hoko River (45TN240) and Sunken Village (35MU4) artifact assemblages indicate that most basketry at both sites was made of western red cedar (Thuja plicata) (Croes et al. 2005, 2009, 2008; Byram 2002).

Six wood samples collected from five modified wooden stakes from the Virginia Lake site were submitted to Paleoscapes Archaeobotanical Services Team (PAST) for macrobotanical Identification. PAST broke wood fragments to expose fresh tangential, radial, and cross-sections. The samples were then examined under a Bausch and Lomb Stereozoom microscope at a magnification of 70x and a Nikon Optiphot 66 microscope at magnifications of 100-600x (Appendix D). 


\subsection{Regional Comparisons}

I conducted regional comparisons to further investigate cultural affiliation and possible functions of the feature, against the broader landscape of human modification in wetlands of the Lower Columbia, in both precontact and historic contexts.

The comparative sample is idiosyncratic; selection was based on the location, age, presence of like-features (e.g. wood stakes or similar structures), and availability of data on methodology, and high-quality images. Because of limitations present in searching the Oregon State Historic Preservation Office (SHPO) site database, sites containing wooden stakes or like structures in the Lower Columbia were difficult to locate. The database is searchable by site designation or report title. This excludes searches by key words present in site form or report, or by specific feature or site type. The sites used in my analysis were predominantly identified based on prior knowledge, and information provided by local researchers and archaeologists. This sample is by no means a definitive comparison of wood stake sites in the region.

I took the data obtained from the Virginia Lake site and compared it to four sites (45CL31, 35MU4, 35CO87, and 35CO88) containing wooden stakes, or stake-like features, previously recorded in wetlands of the Lower Columbia. Specifically, I compared stake diameter, length, spacing, number, approximate size of features, associated artifacts, age of the site, cultural affiliation, and macrobotanical identification. When available dates were reported as uncalibrated, I used OxCal version 4.3 to calibrate radiometric dates for this project. 


\section{Chapter 4: Results}

In this chapter I summarize the results of my archival research, fieldwork, lab analysis, and regional comparison. Specifically, I discuss the results of the survey and feature specific testing, toolmark modification analysis, AMS dating, and macrobotanical analysis. I also compare my results to four sites with stake features previously recorded in wetlands of the Lower Columbia.

\subsection{Archival Researchand Map Review}

Results of archival research, which provided property ownership history, are primarily summarized in the postcontact history section of this document (Section 2.2). Archival research did not uncover information related to the origin of the stake alignment.

Of particular importance to my project is determining the history of Virginia Lake, specifically its chronology as a water body separated from the Multnomah Channel, and the impacts of levee construction. Historic maps and aerial imagery indicate that Virginia Lake was separate from the main Multnomah Channel at the time of EuroAmerican settlement (USACE 1929; GLO 1854). Maps created after the passage of the Flood Control Act in 1936, which stimulated large scale levee construction, indicate that the lake persisted in a similar form after the levees were installed, although it may have become more prone to seasonal drying (GLO 1854; USGS 1915, 1940, 1954). Further information about the history of lake formation is discussed in Section 4.3 under AMS dating results. 
Review of historic maps included GLO maps $(1862,1854)$, associated surveyor's notes, and USGS Topographic maps $(1915,1940,1956)$. Historic maps indicate that Virginia Lake, and the stake feature in particular, is located directly south of the 640 acre DLC belonging to Isabelle Logie (DLC 49), and west of the 638.9 acre DLC belonging to Jacob Cline (DLC 48) (Figure 8). The Cline claim was the first land claim filed on Sauvie Island, and the Logie claim the second, placing the feature proximal to the earliest documented U.S. controlled Euro-American settlements (GLO 1862; Spencer 1950).

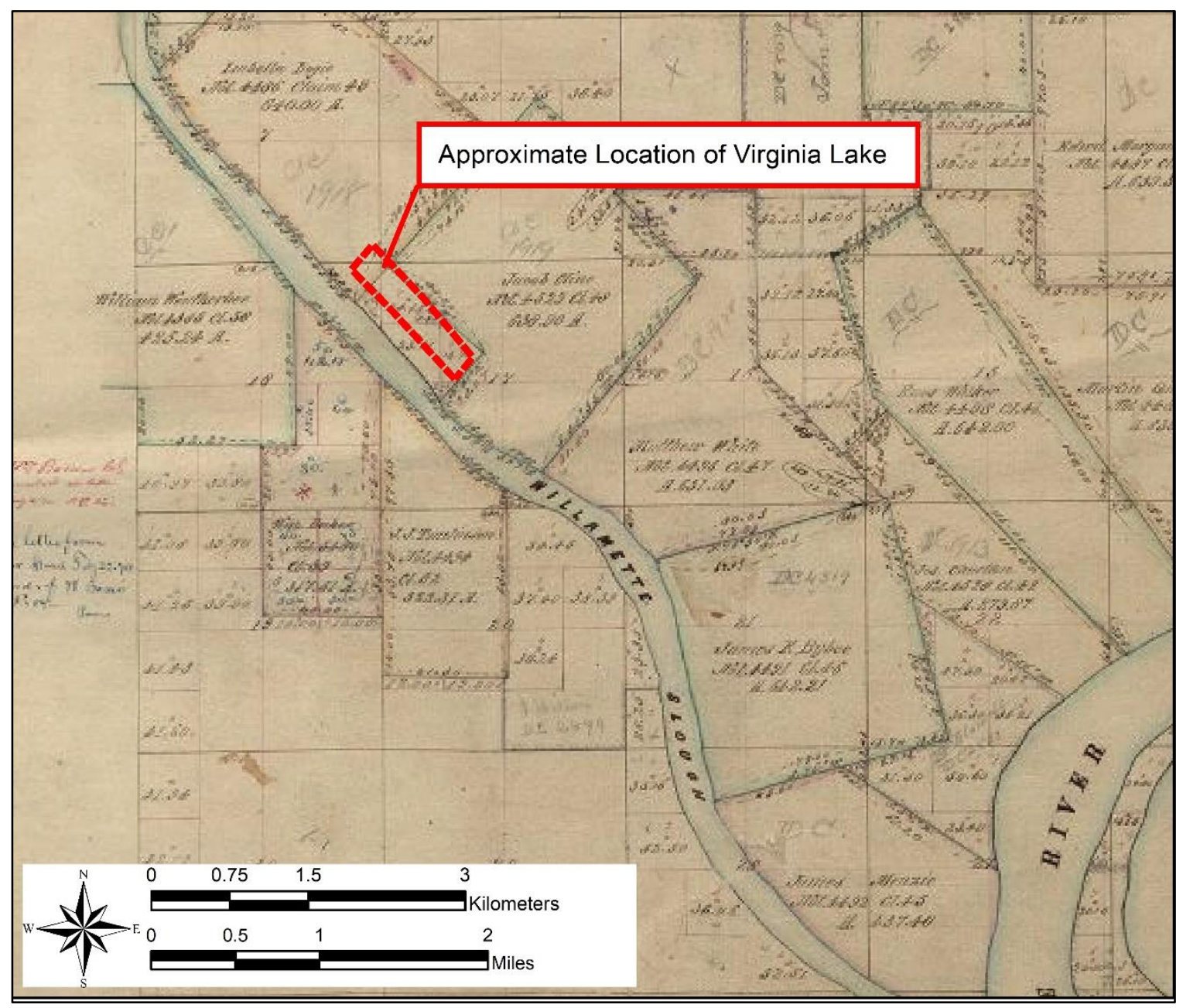

Figure 8. 1862 GLO map of Sauvie Island in the vicinity of Virginia Lake. 
There are no structures shown within Virginia Lake, or adjacent the feature, and the lake was not mapped as part of a DLC as of 1862 (Figure 8, Figure 9). The project area is located west of an area described on the 1854 GLO as a "Fir and Oak Timbered Ridge" with the labeled claims located on higher ground above the ridge. The surveyor of the Cline claim specifically noted a "pond" to the west of the claim in his notes, which likely refers to Virginia Lake (Ives and Hunt 1853).

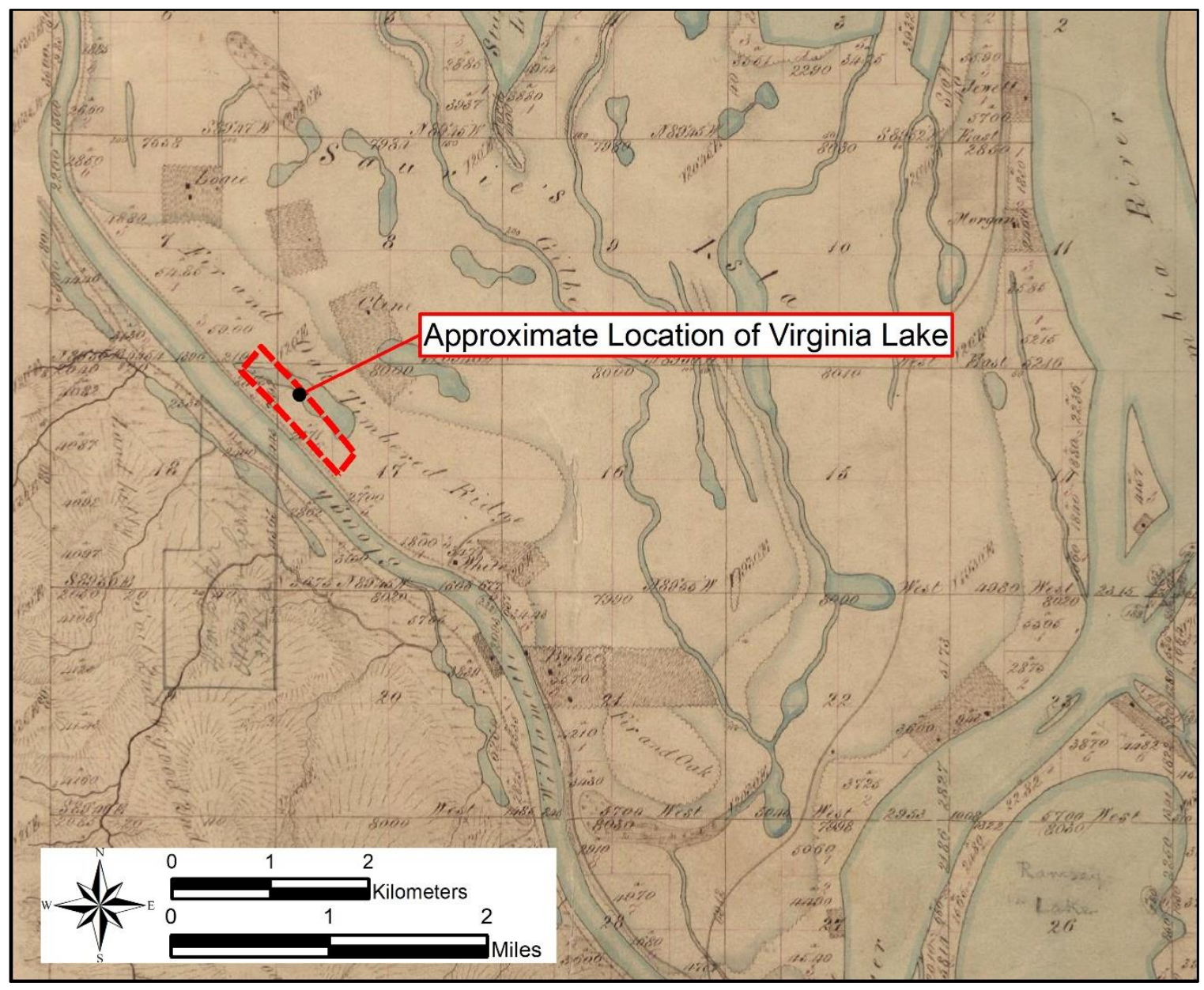

Figure 9. 1854 GLO map of Sauvie Island and the Virginia Lake vicinity. 


\subsection{Field Work Results}

Fieldwork consisted of pedestrian survey, subsurface testing, and collection of both wood and sediment samples. During fieldwork the feature was also recorded in detail, and its spatial location mapped. The following section summarizes the results of this work

\section{$\underline{\text { Pedestrian Survey }}$}

Pedestrian survey was conducted across the vegetated surface of Virginia Lake to place the stake alignment in a wider context (Figure 10, Figure 11). In total we surveyed approximately 65 acres. Ground visibility was severely limited due to an abundance of vegetation on the dry lake bottom, most commonly invasive reed canary grass (Phalaris arundinacea). The culturally important plant species wapato was also observed in a few small patches of the lakebed.

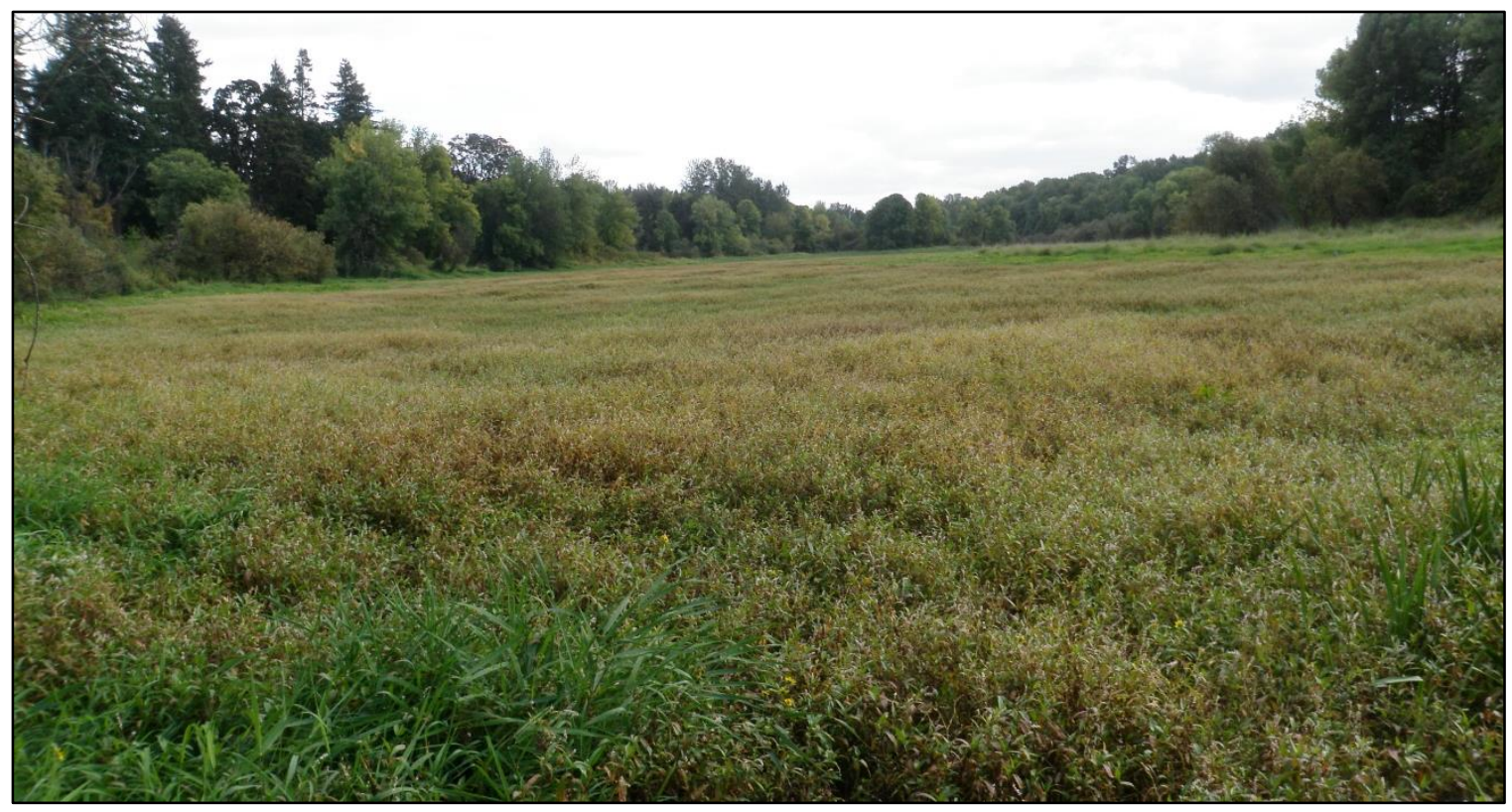

Figure 10. Overview of Virginia Lake survey area with abundant vegetation, view south. 
During pedestrian survey the crew gave particular attention to the few areas of sediment exposure, such as exposed banks, and recent disturbance. No definitively precontact sites or isolates, represented by lithic artifacts or fire cracked rock, for example, were observed during pedestrian survey. However, twelve features were identified at isolated locations (Figure 12, Table 3). Specifically, we recorded a series of round and split wood posts, a ditch, two metal pipes, a metal gauge, and two pilings and an associated concrete paver (Table 3). In addition, we observed the remains of what is most likely the footprint of a duck blind/hunting platform (Figure 13).

Hunting platforms/blinds allow the hunter to wait for game above the water on a platform, sometimes visually obscured behind a screen, wood panel, netting, or brush. These structures are usually square or rectangular, large enough for a person to wait comfortably, and can be temporary mobile structures, stationary fixtures, or floating. The possible hunting platform/blind observed during survey is constructed of four, dimensional lumber posts, arranged in a square. The posts likely supported a platform.

All the features appear to be modern or from the late $19^{\text {th }}$ and $20^{\text {th }}$ century based on the presence of dimensional lumber and metal nails. Archival research did not uncover further information relating to their function or age. The ditch recorded on the northwestern side of the lake is visible on LiDAR (Figure 11), and may represent an attempt to drain the lake for agricultural reasons (Oregon Parks and Recreation Department 2013). 


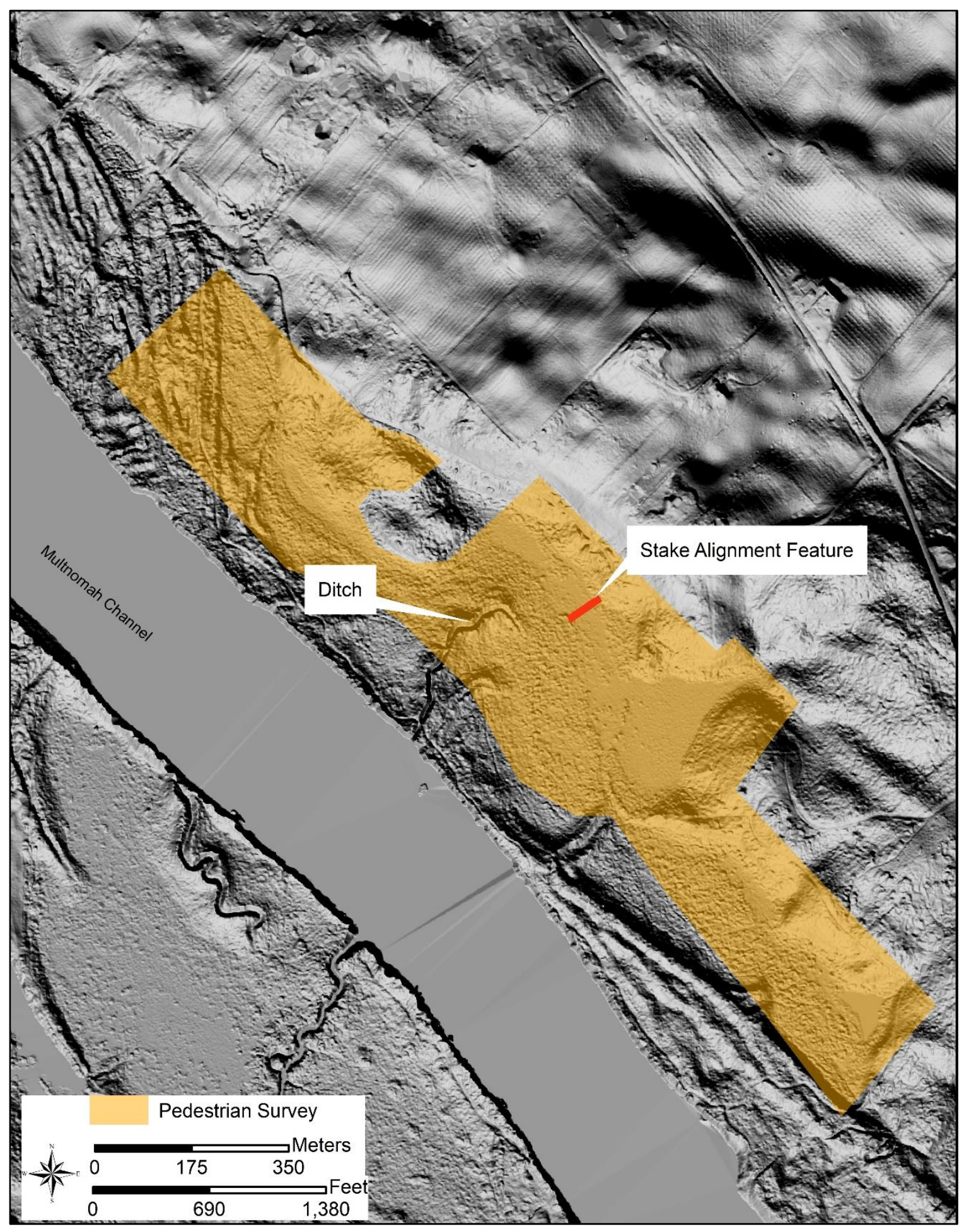

Figure 11. LiDAR image depicting area surveyed. 
Table 3. Features identified during pedestrian survey.

\begin{tabular}{cc}
\hline Feature & Number of Eements \\
\hline Wood post & 1 \\
Wood post & 4 \\
Split cedar post & 1 \\
Wood post & 1 \\
Wood post & 1 \\
Piling (2) Concrete paver (1) & 3 \\
Hunting platform/blind (dimensional lumber) & 4 \\
Metal pipe & 1 \\
Metal pipe & 1 \\
Split cedar post & 2 \\
PVC and metal gauge & 1 \\
Ditch & 1 \\
\hline
\end{tabular}

The features recorded during the lake basin survey are some distance from the stake alignment, the focus of my project. The nearest feature, a ditch, is approximately $140 \mathrm{~m}$ west of the stake alignment (Figure 12). None of the other stake features documented during survey are similar to the Virginia Lake stake alignment (e.g. form double linear alignments, or containing more than four stakes). 


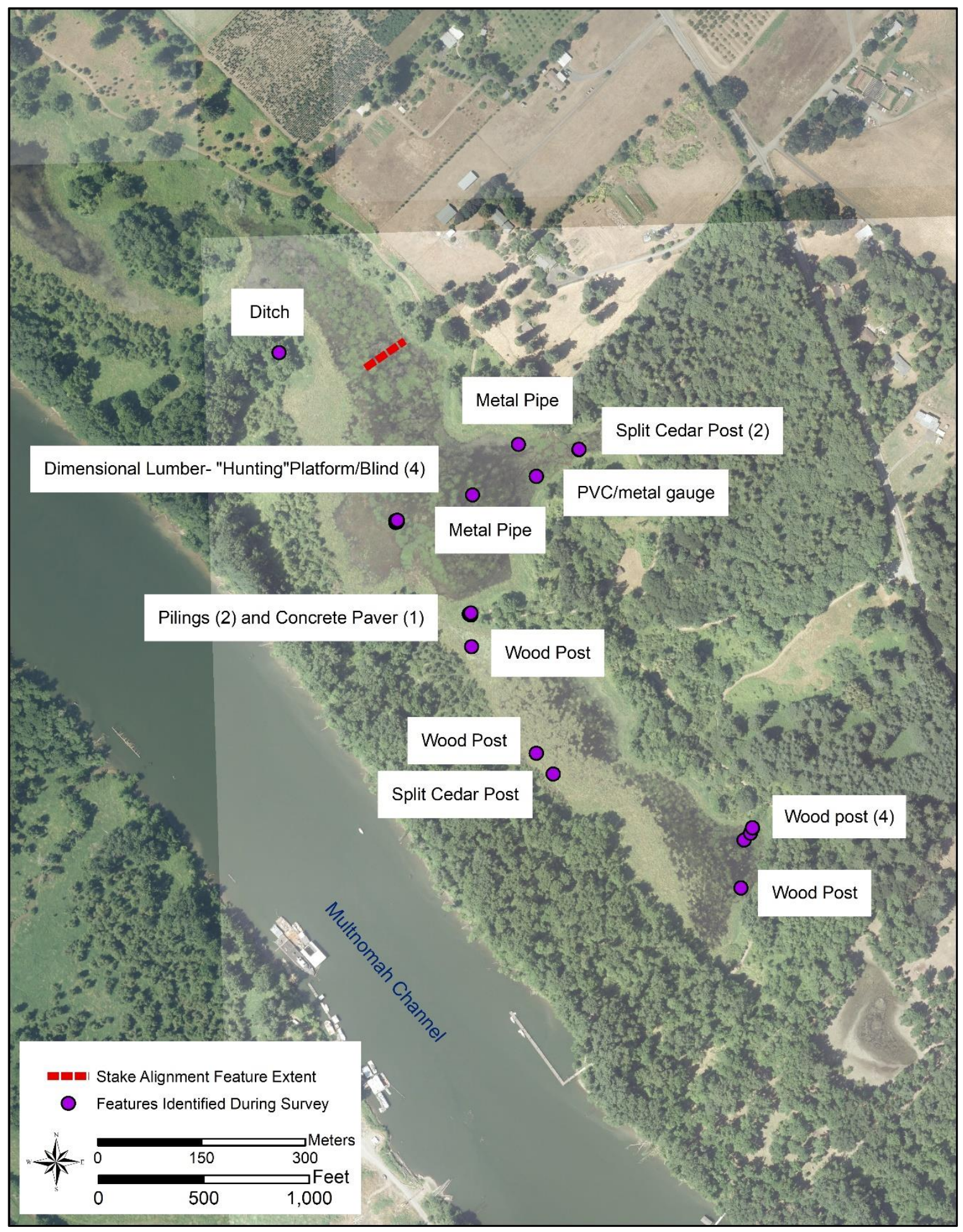

Figure 12. Locational map of features identified during pedestrian survey. 


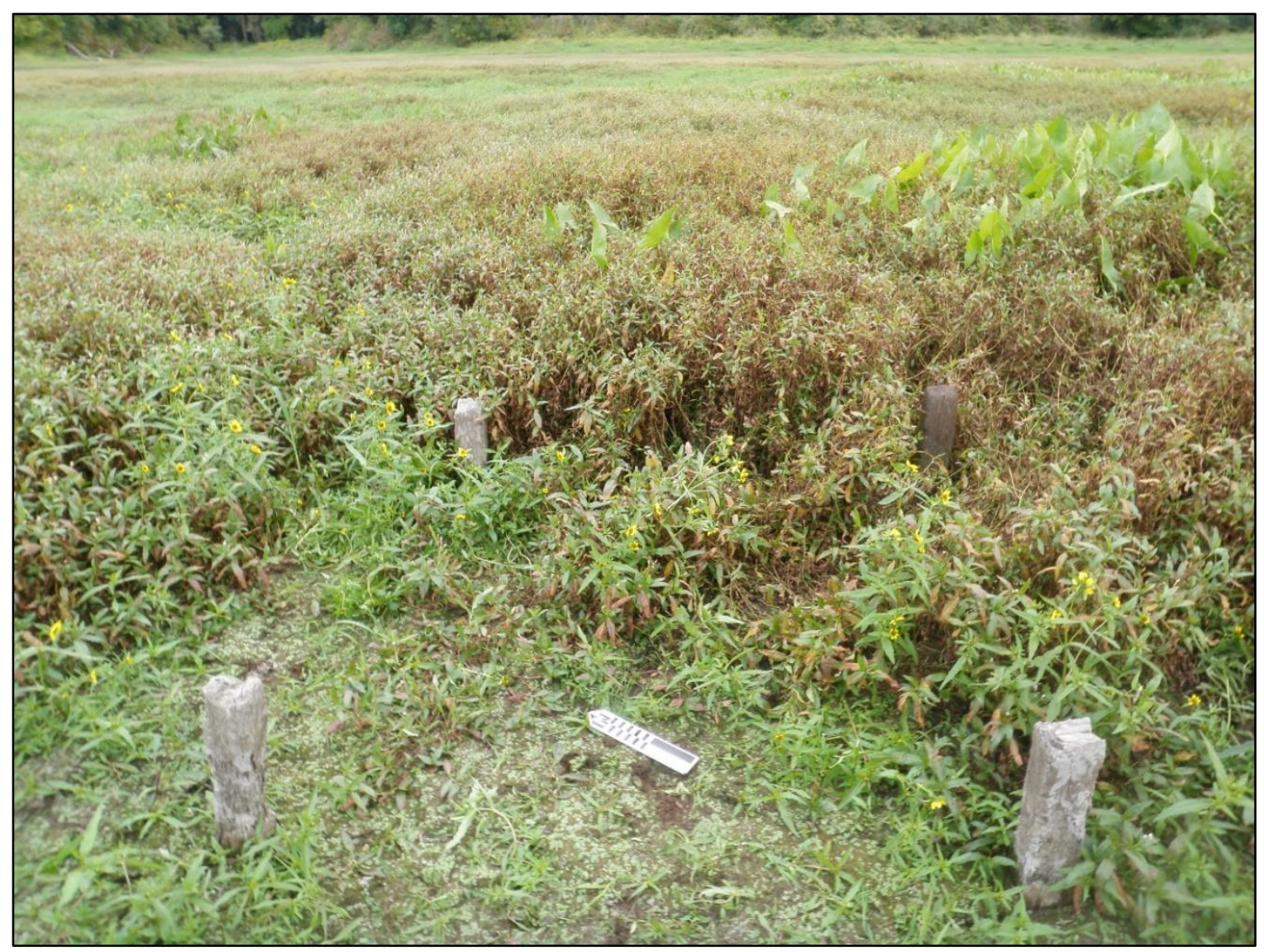

Figure 13. View northeast, possible hunting platform/blind made of dimensional lumber identified during pedestrian survey.

\section{Overview of the Stake Alignment Feature}

During fieldwork, the crew recorded a total of 23 wooden stakes both above and below the surface as part of the Virginia Lake feature (Figure 2, Figure 6, and Figure 14). The alignment extends approximately $60 \mathrm{~m}$ (196 ft) into the lake, but does not fully cross it, originating near a rise in elevation signifying the shore, travelling along the lake bottom, and ending before the elevation rises again on the opposite shore (Figure 15). The lakebed is approximately 3 meters lower in elevation than the adjoining bank, indicating that with the lake's current configuration, the water level can rise up to approximately three meters before overbank flooding occurs at the location of the feature. 
To estimate stake size, I measured the maximum diameter at the top and base of each stake (Table 4). Individual stakes measured an average of $5.9 \mathrm{~cm}(\mathrm{SD}=1.9)$ in diameter at the base, and $25.6 \mathrm{~cm}(\mathrm{SD}=20.4)$ in height above surface (Table 4). The two stakes I removed measured $123 \mathrm{~cm}$ and $95 \mathrm{~cm}$ long. Stakes are generally roughly round in cross section, and spaced approximately $2.5 \mathrm{~m}$ apart in a linear alignment, oriented northeast by southwest (Figure 6). However, gaps exist within this alignment, creating occasional spaces greater than $2.5 \mathrm{~m}$ (Figure 6).

In six cases, the stakes appeared to occur in a pair (Figure 6, Figure 14). As discussed above, the alignment generally runs northeast by southwest. When a stake was positioned to the north of this alignment, roughly perpendicular to another stake, it was considered a pair. These paired stakes create a partial parallel alignment. Distance between paired stakes varies between 50 and $77 \mathrm{~cm}$. Paired stakes 13 and 14, excavated in TU2, were not vertical. Both stakes tilted slightly away from each other, with the distal ends closer together than the proximal.

Intensive pedestrian survey and subsurface testing within and immediately adjacent to the feature identified six stakes that were not previously documented. Two of these stakes, numbered 21 and 23 , were not visible at the surface and identified solely as a result of subsurface testing (Table 4). These subsurface stakes are paired with Stakes 19 and 2 respectively. Subsurface tests SP1, SP4, SP5, and TU1 were judgmentally placed with the intention of determining if stakes may be present below the surface because the above ground portion had eroded away (Figure 5). This placement was based on measured distance between visible pairs, and tests were excavated where gaps existed. 
Possibly due to the variation in spacing, additional pairs were only identified in two of these tests. However, it is possible that at one time some or perhaps all stakes within the alignment were paired, and the current inconsistency in pairing is a result of differential preservation, not an indication of the feature's original construction.

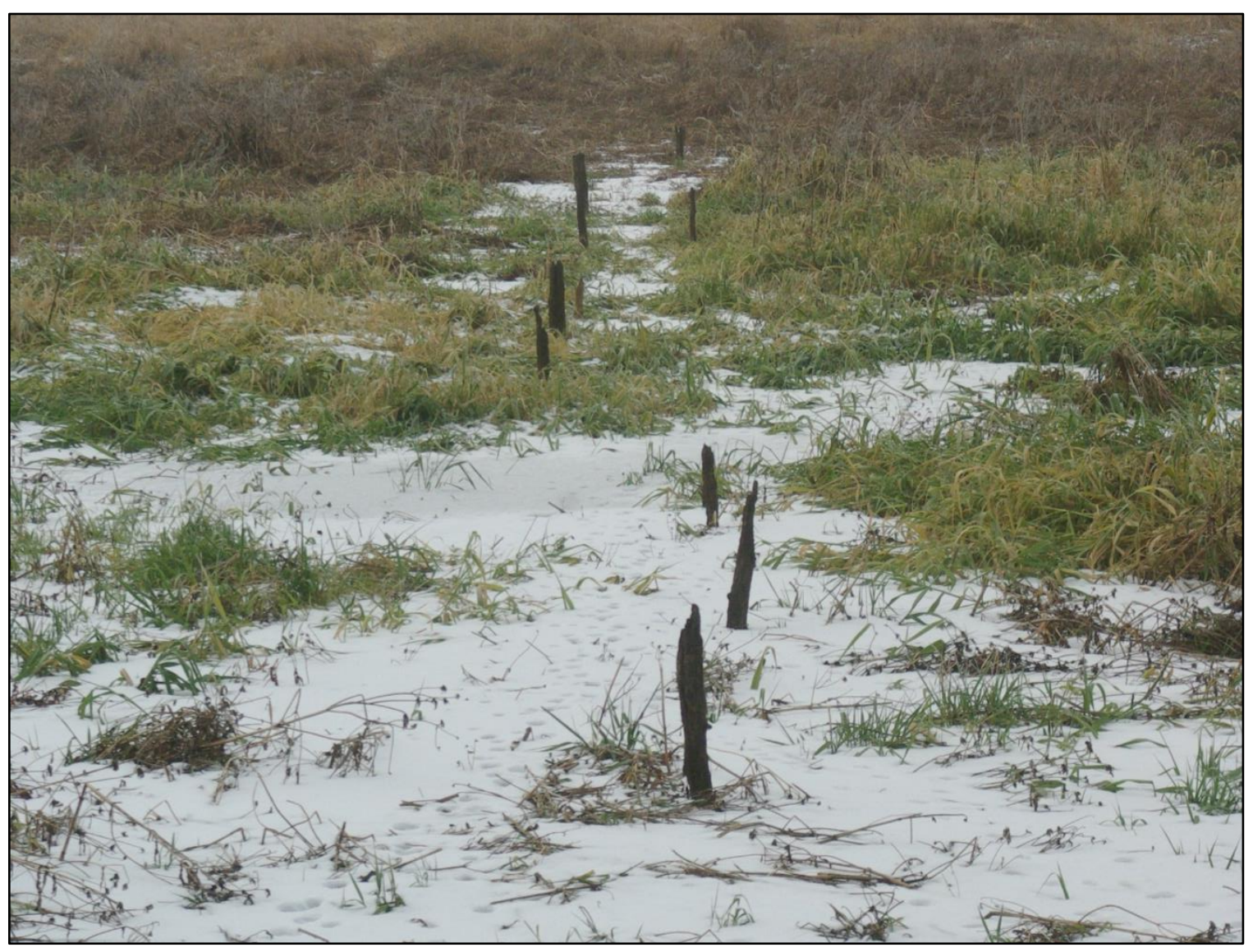

Figure 14. Virginia Lake stake alignment (note pairing towards top of photograph). View northeast, image courtesy of Dennis Torresdal.

The metal detector survey identified three stakes that possibly contain metal.

Metal was visible embedded in two of the stakes (Stakes 10 and 12). The metal objects were left in place so as not to damage the stake, but were recorded. In both cases, the metal resembled nails. However, if nails, the heads were not intact, and both were heavily corroded. 
Height and diameter of the stakes is not uniform throughout the feature. The tops of the stakes, which are subject to more frequent exposure, exhibit notably poorer preservation than the bases. Specifically, the stake bases on average measured $1.7 \mathrm{~cm}$ larger than the tops and were more robust (Table 4). This information is relevant, as it confirms that the base diameter of the stakes is a more accurate measure of original size. This information also indicates that exposure to air contributes to degradation of stakes, and that the oscillating cycles of inundation the feature has endured have likely contributed to its current state of preservation.

Not only did the stake diameter vary from top to base of stake, but the height of the stakes from the ground surface also displays substantial differences (Figure 16). Stake height varied from 0 to $60 \mathrm{~cm}$ above surface. If the feature was built all at once, then it should be more uniform, unless the original feature was built without concern for standardization, or there are post depositional processes such as air exposure, weathering, or insect damage, that have had an uneven effect.

Due to effects of air exposure on the diameter of the stakes, I investigated if distance of the stakes from shore might impact the frequency of their inundation, which may have contributed to the variation in size. However, measuring the height of the stake from the surface and comparing it to the stake's position relative to shore did not indicate any patterning (Figure 17). This implies that due to the relatively level topography, inundation is likely even, ensuring that stakes are not subject to differential exposure to air. This indicates that original construction, or other post depositional processes have contributed to the seemingly irregular condition of the stakes. 
Ten stakes had visible bark. Stakes without visible bark are likely the result of decay, not intentional modification. However, poor preservation makes it difficult to accurately discern more subtle forms of intentional modification, especially to the stake's exterior surface.

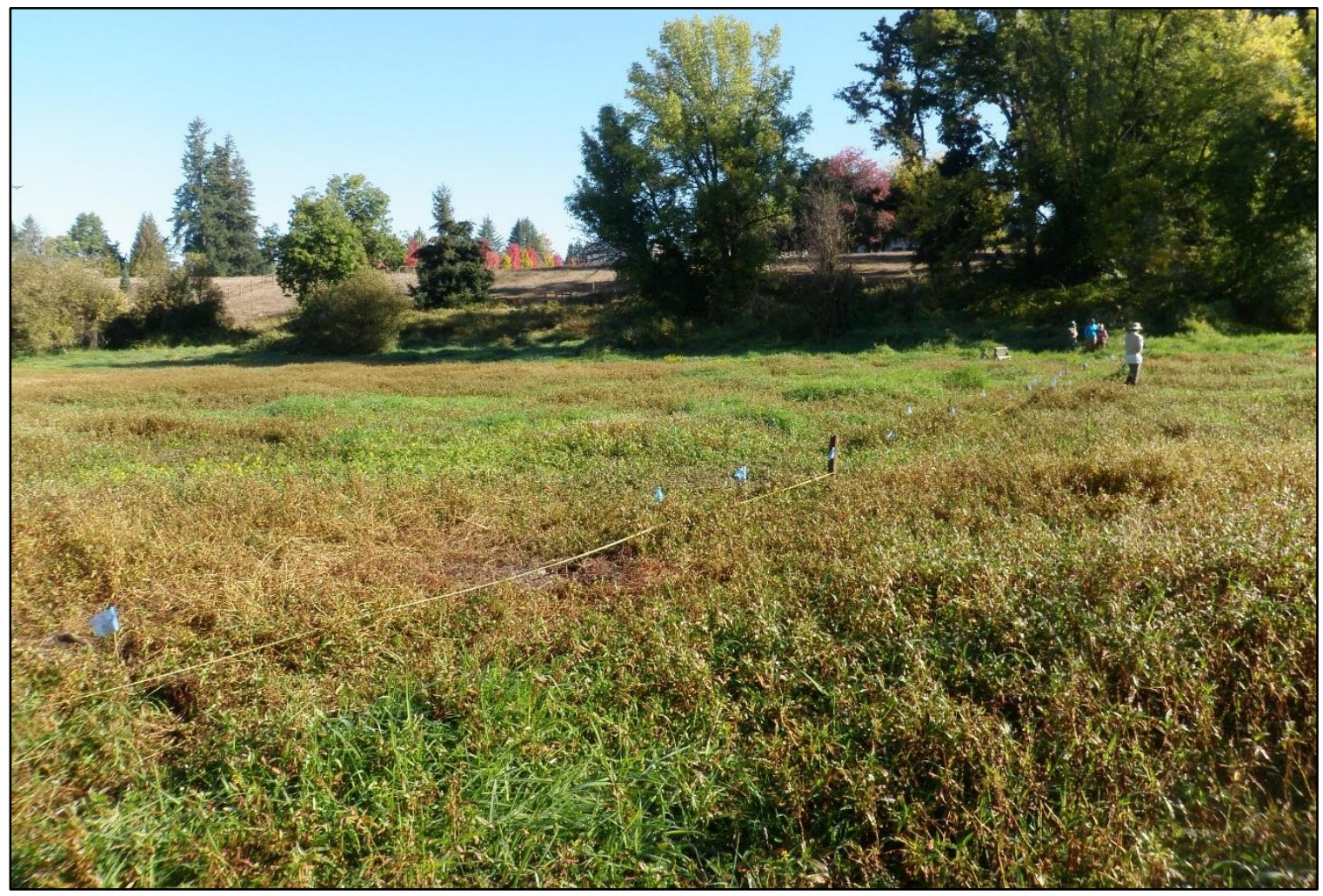

Figure 15. Virginia Lake stake alignment during 2018 fieldwork (blue flags mark stakes). View north. 


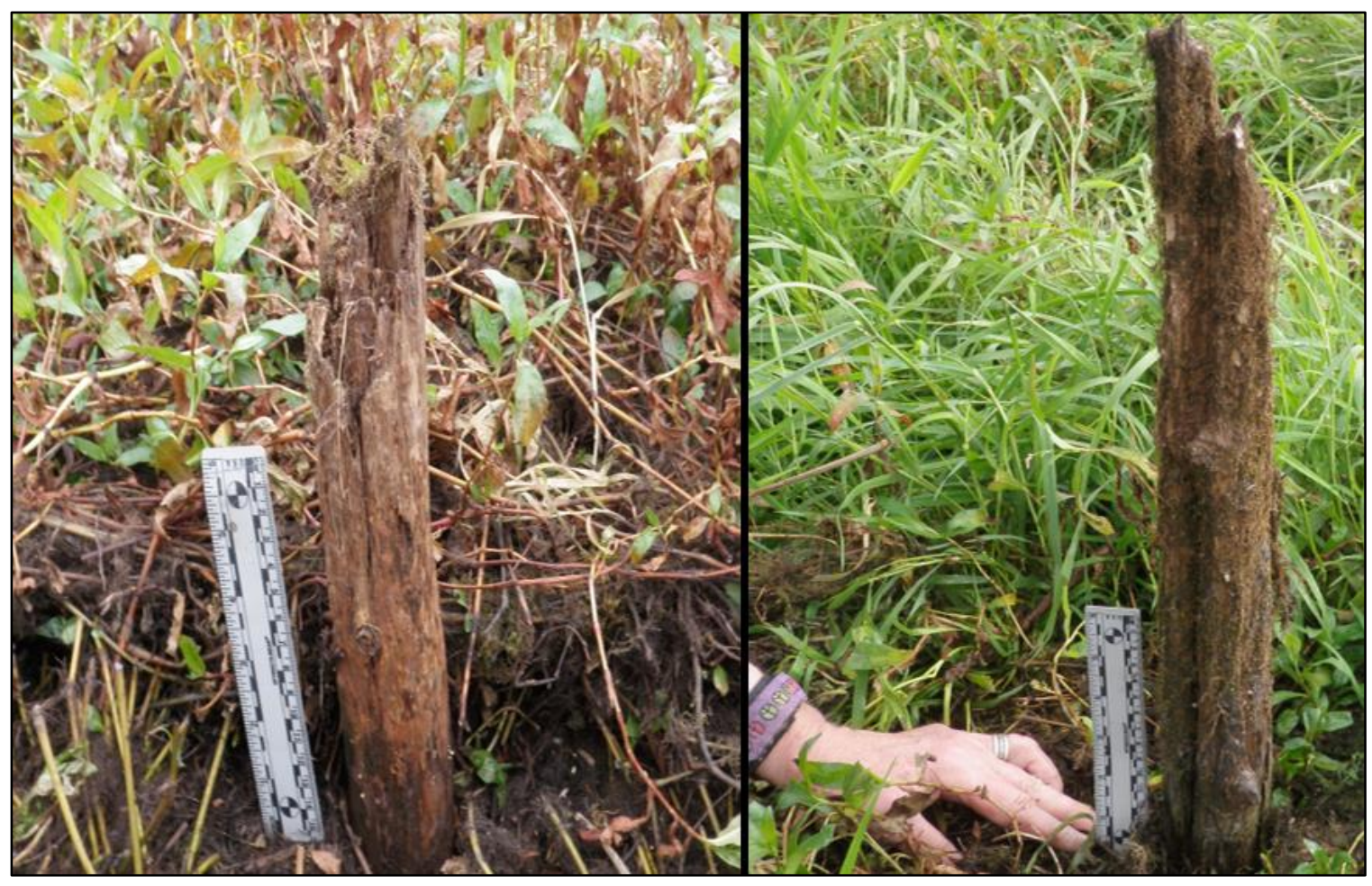

Figure 16. Stake 7 (left), view west and Stake 3 (right), view southeast. Note difference in height.

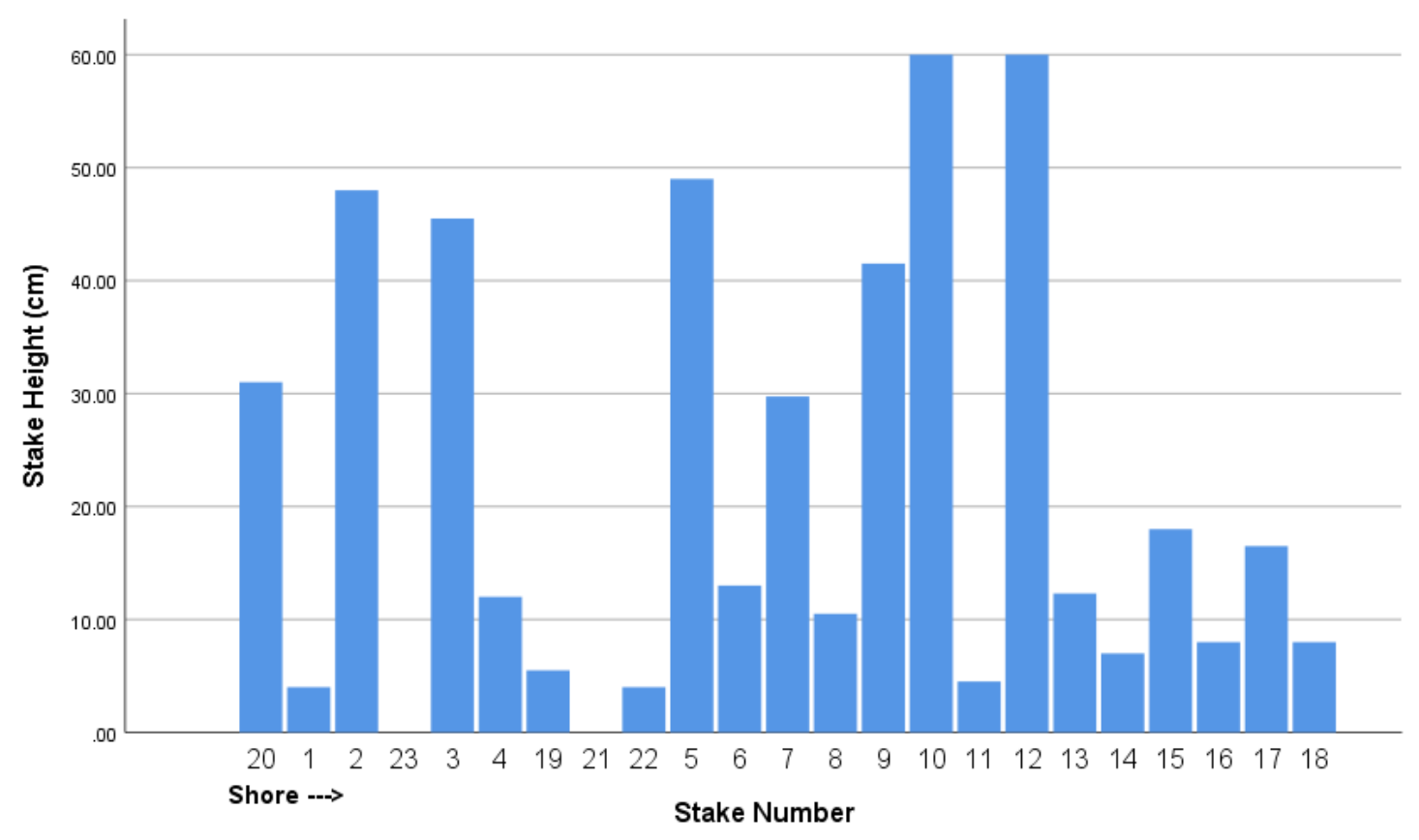

Figure 17. Bar graph depicting relationship between stake height (measured from the ground surface) and position relative to the lake shore, with Stake 20 closest to shore, Stake 18 mid-lake. 
Table 4. Overview of stakes in the Virginia Lake feature.

\begin{tabular}{|c|c|c|c|c|c|}
\hline Stake \# & $\begin{array}{l}\text { Height from } \\
\text { Ground }(\mathrm{cm})\end{array}$ & $\begin{array}{l}\text { Max } \\
\text { Diameter } \\
\text { at Base }\end{array}$ & $\begin{array}{l}\text { Max } \\
\text { Diameter at } \\
\text { Top }(\mathbf{c m})\end{array}$ & $\begin{array}{l}\text { Difference in } \\
\text { Max Diameter } \\
\text { (cm) }\end{array}$ & Comments \\
\hline 1 & 4 & 5.5 & N/A & $\mathrm{N} / \mathrm{A}$ & Very stable to touch, but eroded at top. \\
\hline $2^{*,+}$ & 48 & 5 & 6 & -1 & $\begin{array}{l}\text { Wood is dry to the touch, moderately robust and firm, some } \\
\text { longitudinal cracks but overall good integrity; removed. Roughly } \\
\text { round. After removal max diameter is } 6.86 \mathrm{~cm} \text {. }\end{array}$ \\
\hline 3 & 45.5 & 5.5 & 4.5 & 1 & $\begin{array}{l}\text { Split down center, very stable to touch, moss growth. Round. Visible } \\
\text { bark. }\end{array}$ \\
\hline 4 & 12 & 7 & N/A & $\mathrm{N} / \mathrm{A}$ & Eroded, likely broken off at top \\
\hline 5 & 49 & 6 & 3.5 & 2.5 & $\begin{array}{l}\text { Highly eroded, black surface near top, split partially through, some } \\
\text { moss at surface, previously removed and replaced. Round, visible bark. }\end{array}$ \\
\hline 6 & 13 & 2.5 & 1.75 & 0.75 & Extremely poor condition, round, visible bark. \\
\hline $7^{*}$ & 29.75 & 5 & 4.5 & 0.5 & $\begin{array}{l}\text { Robust at base. Top has open structure. Round, no bark (knot visible } \\
1 / 5 \text { way up, flush with stake). In situ sample. }\end{array}$ \\
\hline 8 & 10.5 & 4.75 & 3 & 1.75 & Very eroded, visible bark. \\
\hline 9 & 41.5 & 4 & 2 & 2 & Round at base, at least 2 knots, visible bark. \\
\hline $10^{\mathrm{M}}$ & 60 & 5 & 3.5 & 1.5 & $\begin{array}{l}\text { Excellent condition, round. Possible metal exposed at } 25 \mathrm{~cm} \text { from base } \\
\text { E / } 26 \mathrm{~cm} \text { from base, visible bark. }\end{array}$ \\
\hline
\end{tabular}




\begin{tabular}{|c|c|c|c|c|c|}
\hline Stake \# & $\begin{array}{l}\text { Height from } \\
\text { Ground }(\mathbf{c m})\end{array}$ & $\begin{array}{l}\text { Max } \\
\text { Diameter } \\
\text { at Base }\end{array}$ & $\begin{array}{l}\text { Max } \\
\text { Diameter at } \\
\text { Top }(\mathbf{c m})\end{array}$ & $\begin{array}{l}\text { Difference in } \\
\text { Max Diameter } \\
(\mathrm{cm})\end{array}$ & Comments \\
\hline 11 & 4.5 & 5.25 & 5.25 & 0 & $\begin{array}{l}\text { Oblong, original shape difficult to discern given erosion. Outer surface } \\
\text { eroded. }\end{array}$ \\
\hline $12^{*}, \mathrm{M}$ & 60 & 8.25 & 10.25 & -2 & $\begin{array}{l}\text { Metal in NW side at } 45.25 \mathrm{~cm} \text { from base. In situ sample. Noticeably } \\
\text { better condition than most other stakes, round. }\end{array}$ \\
\hline $13^{*,+}$ & 12.3 & 8.5 & 2.5 & 6 & $\begin{array}{l}\text { Longitudinal crack. Degraded to point, friable at top. Paired with S14, } \\
77 \mathrm{~cm} \text { between stakes. Removed from TU2. Round, visible bark. After } \\
\text { removal max diameter is } 11.2 \mathrm{~cm} \text {. }\end{array}$ \\
\hline 14 & 7 & 8.5 & N/A & N/A & $\begin{array}{l}\text { 30 deg tilt. Very little above surface. In wall of TU2, not fully } \\
\text { excavated so diameter measurement not possible. Left in place. Round. } \\
\text { Paired with } 13 \text {. }\end{array}$ \\
\hline 15 & 18 & 7 & 4.5 & 2.5 & $\sim 5$ deg tilt, Round, visible bark. \\
\hline 16 & 8 & 4 & 1.75 & 2.25 & $\begin{array}{l}\text { Rectangular in cross section with obvious erosion. Towards base } \\
\text { seeing outer growth suggesting stake is a remnant core, not original } \\
\text { shape of wood }\end{array}$ \\
\hline 17 & 16.5 & 7.25 & 6 & 1.25 & Unevenly eroded, splits open at top and around main body, rounded. \\
\hline 18 & 8 & 7 & N/A & N/A & Extremely eroded. Very decomposed, round. \\
\hline 19 & 5.5 & 4.5 & N/A & N/A & Unevenly eroded, round. \\
\hline 20 & 31 & 7 & 6 & 1 & Moss covered, eroded, but stable, round. Visible bark. \\
\hline
\end{tabular}




\begin{tabular}{|c|c|c|c|c|c|}
\hline Stake \# & $\begin{array}{l}\text { Height from } \\
\text { Ground }(\mathrm{cm})\end{array}$ & $\begin{array}{l}\text { Max } \\
\text { Diameter } \\
\text { at Base }\end{array}$ & $\begin{array}{l}\text { Max } \\
\text { Diameter at } \\
\text { Top }(\mathbf{c m})\end{array}$ & $\begin{array}{l}\text { Difference in } \\
\text { Max Diameter } \\
\text { (cm) }\end{array}$ & Comments \\
\hline $21^{*}$ & Subsurface & 5 & 4 & 1 & $\begin{array}{l}\text { Waterlogged, soft, condition improves with depth. Found in } \mathrm{N} \text { wall of } \\
\text { ST1, paired with Stake } 19 \text {. In situ sample. Completely subsurface. } \\
\text { Extends } 56 \mathrm{~cm} \text { below surface. }\end{array}$ \\
\hline 22 & 4 & 3 & N/A & N/A & Rectangular \\
\hline 23 & Subsurface & N/A & N/A & N/A & $\begin{array}{l}\text { Located in SW wall TU1, completely subsurface. } \sim 15 \text {-degree tilt, } \\
\text { visible, } \sim 27 \mathrm{~cm} \text { below surface. Not fully excavated so diameter } \\
\text { measurement not possible. }\end{array}$ \\
\hline $2^{\mp}$ & & 6.86 & 6 & 0.86 & Stake is $123 \mathrm{~cm}$ long, see above for pre-removal measures. \\
\hline $13^{\mathrm{F}}$ & & 11.2 & 2.5 & 8.7 & Stake is $95 \mathrm{~cm}$ long, see above for pre-removal measures. \\
\hline \multicolumn{4}{|c|}{ Average Difference: } & $1.7 \mathrm{~cm}$ & \\
\hline Mean & 25.6 & 5.9 & 4.3 & & \\
\hline SD & 20.4 & 1.9 & 2.1 & & \\
\hline
\end{tabular}

${ }^{+}$Stake removed for analysis

* Sampled for AMS dating

${ }^{\mathrm{r}}$ Description after removal

${ }^{\mathrm{M}}$ Stake contains metal 


\section{$\underline{\text { Subsurface Shovel Probing and Feature Specific Testing }}$}

During subsurface testing, we excavated a total of 11 shovel probes (SP1 to 11) and two $1 \times 0.5 \mathrm{~m}$ test units (TU1, TU2), and processed a total of $1.585 \mathrm{~m}^{3}$ of sediment. Shovel probes were excavated in and adjacent to the feature. As previously discussed, because stake pairing was visible at the surface in select places in the alignment, three SPs were placed to determine if paired stakes may be present below the surface, their above ground portion having eroded away. Test units were excavated directly adjacent to stakes that we intended to remove (Figure 5, Figure 18, Figure 19). The only artifacts or features identified during subsurface testing were the stakes themselves. No artifacts, fauna, lattice, or other cultural materials (e.g. buckshot or ammunition) were observed during subsurface testing, or subsequent screening of collected bulk samples.

Shovel probes averaged $57.5 \mathrm{~cm}$ below surface in depth, generally terminating at the water table. In SP2 and SP3 a long handle auger was used to extend the depth of excavation to $165 \mathrm{~cm}$, and $155 \mathrm{~cm}$, respectively.

The crew excavated TU1 to $67.5 \mathrm{~cm}$ below datum ( $\sim 59 \mathrm{~cm}$ below surface). TU2 excavations terminated at $67 \mathrm{~cm}$ below datum $(\sim 58 \mathrm{~cm}$ below surface). As with the SP, we used a long handle auger to extend the depth of excavation in both TU. TU1 was augured to $140 \mathrm{~cm}$ below surface, and TU2 was terminated at $165 \mathrm{~cm}$ below surface before auger recovery ceased due to wet and loose sediments.

Sediments in both the SPs and TUs primarily comprised a 10YR 3/2 very dark greyish brown to GLEY1 4/1 dark grey silty clay loam with high organic content and no gravels. This matrix and its variants are identified as local hydric soil, indicative of 
wetland environments with slow to little water movement, such as in a lake or slow perennial slough. Redoximorphic concentrations, caused by the oxidization and reduction of iron and/or manganese in soil, and indicative of water saturation, were common lower in the profile as we approached the water table. Sediment at the base of both TUs broke in polygonal patterns, likely the result of water action and repeated cycles of inundation and drying. Deeper auguring encountered a fine to medium grained sandy matrix, indicating a higher energy depositional environment such flood events, or a river channel, and a highly organic, fibrous, peat-like matrix. The peat-like matrix is indicative of lower energy depositional environment, such as a lake.

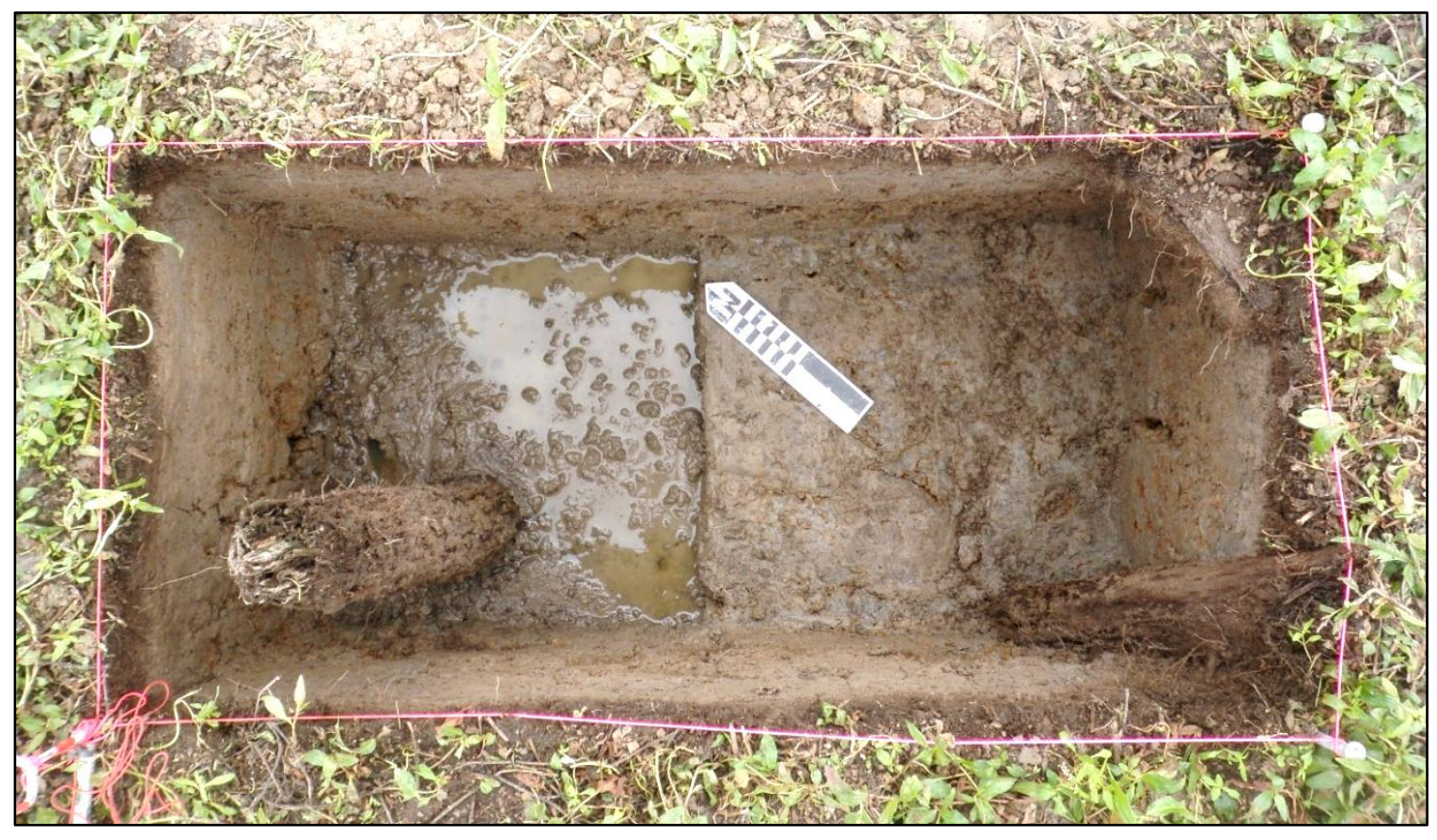

Figure 18.TU2 level 6, base of unit, prior to removal of Stake 13 (left). Note Stake 14 oriented horizontally from the sidewall at right. 


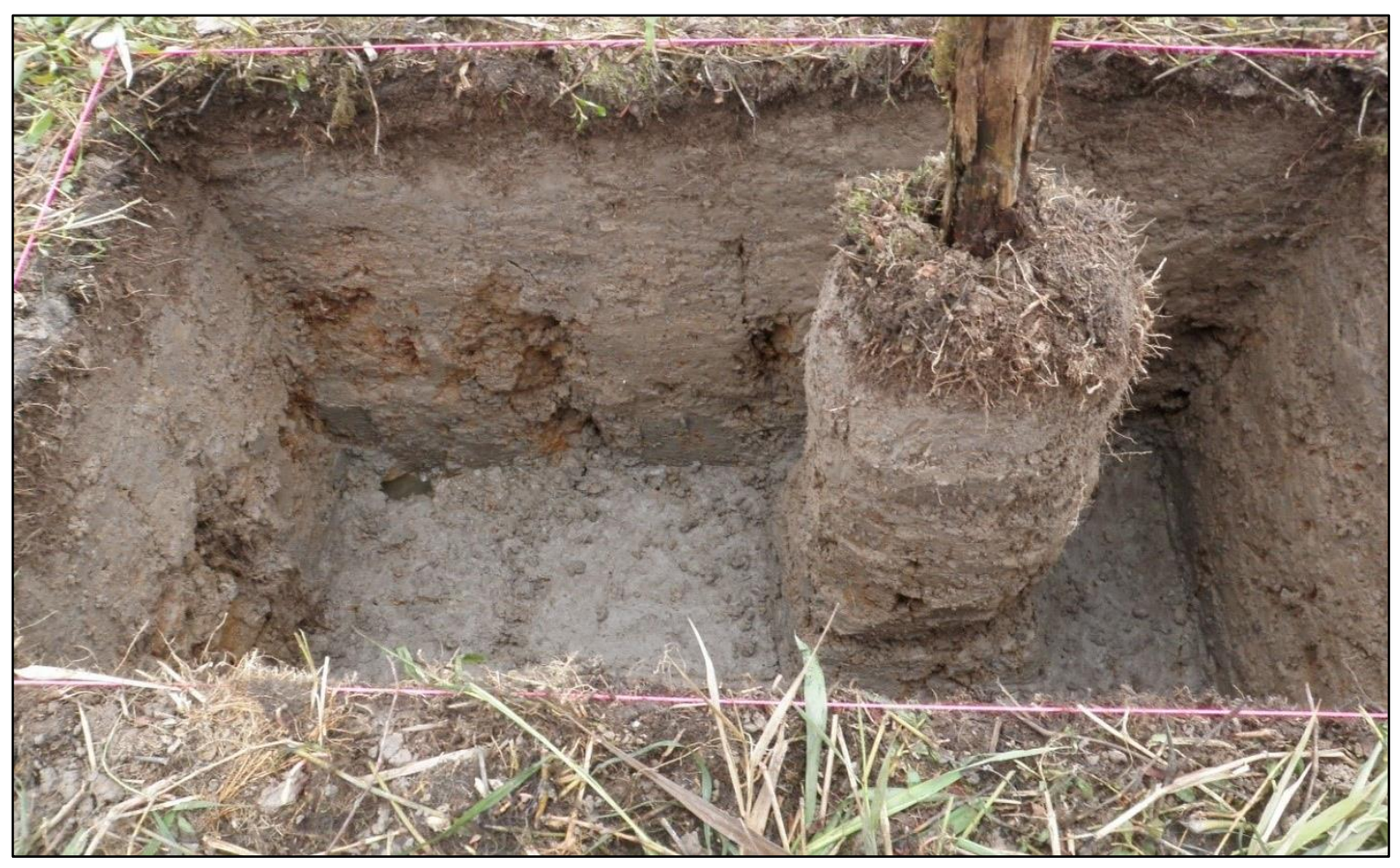

Figure 19. TU1 southwest wall profile, prior to removal of Stake 2.

\subsection{Lab Analysis Results}

\section{$\underline{\text { Toolmark Modification Analysis Results }}$}

I carefully inspected both collected stakes for modification. Stake 2 did not show any evidence of cutmarks or shaping, even after cleaning and inspection under magnification. However, the distal end of Stake 2 was ragged and heavily degraded, indicating that any modification, if present, had broken off. Stake 13 had clear distal modification and was analyzed using the toolmark modification analysis protocol outlined in Chapter 3. I identified five separate tool marks on Stake 13 (Figure 20 and Figure 21). 
When I compared the results to the tool classes developed by Arcas Associates (1986), all five tool marks most closely resembled the criteria for an iron axe (class 1), or iron chisel and maul technology (class 2 and 3) (Table 5-Table 7). However, none of the five marks perfectly aligned with criteria for either iron axes or iron chisels and mauls. Pertaining to Stake 13 toolmarks, Variable I most closely aligned with class 1 (Table 5), whereas Variables II through $\mathrm{V}$ most closely resembled measurements from classes 2 and 3. Variable $\mathrm{V}$ was indicative of class 1, 2 and 3 (Table 5-Table 7). Interestingly, one stake (Stake 5) which was removed, photographed, and replaced by a local landowner prior to this project, appears to also have been modified by metal tools (Figure 22). The landowner graciously provided photographs for study. However, this stake was not available for toolmark modification analysis, as it was not excavated, and remains in place.

I experienced difficulties measuring toolmark variables. This is predominantly due to the lack of definitive "landmarks" within toolmark morphology. While the measurements and variables were defined prior to work (Table 2), unlike with other analyses dependent on the measurement of landmarks (e.g. fauna), the landmarks measured here are highly subjective, and depending on the tool, and state of wood preservation, may vary both in clarity and presence on individual marks, leading to increased ambiguity. This reflects what is likely a larger issue of replicability in toolmark analysis conducted on wood. However, these issues factored more into the identification of the toolmarks and their boundaries, and less in replicability of the measures themselves, once the toolmark boundaries were defined. 
Table 5. Arcas Associates (1986) tool mark classes and the tools used to produce them.

\begin{tabular}{ccc}
\hline Class & Associated Tool & Material \\
\hline 1 & Axe & Metal \\
2 & Hand maul and chisel & Metal \\
3 & Hand maul and chisel & Metal \\
4 & Hand maul and chisel & Bone \\
5 & Unknown & Unknown \\
6 & Unknown/ Poss. Chisel & Shell/Bone/Stone \\
7 & Cross cut saw & Metal \\
8 & Chainsaw & Metal \\
9 & Wedge & Wood/Bone \\
10 & Knives/Machete & Metal \\
\hline
\end{tabular}

Table 6. Table created with information from Arcas Associates (1986) tool classes 1-4.

\begin{tabular}{|c|c|c|c|c|c|c|}
\hline Class & $\begin{array}{l}\text { I. } \\
\text { Curvature } \\
\text { of cutting } \\
\text { edge }(\mathrm{cm})\end{array}$ & $\begin{array}{l}\text { II. Shape of } \\
\text { X section } \\
\text { Depth }\end{array}$ & $\begin{array}{l}\text { III. Length } \\
\text { of cutting } \\
\text { edge }(\mathrm{cm}) \\
\text { max width }\end{array}$ & $\begin{array}{l}\text { IV. Max } \\
\text { penetration }(\mathrm{cm}) \\
\text { max length }\end{array}$ & $\begin{array}{l}\text { V. } \\
\text { Neatnes } \\
\text { s of cut }\end{array}$ & $\begin{array}{l}\text { VI. Angle of } \\
\text { attack }\end{array}$ \\
\hline $\begin{array}{l}\text { 1. Steel } \\
\text { Axe }\end{array}$ & $10-15$ & $\begin{array}{l}\text { Flat to } \\
\text { slightly } \\
\text { concave }\end{array}$ & $7-12$ & 6-7 & Clean & $\begin{array}{l}\text { Horizontal or } \\
\text { oblique }\end{array}$ \\
\hline $\begin{array}{l}\text { 2. Iron } \\
\text { chisel }\end{array}$ & $2-5$ & Flat & $3-5$ & $2-3$ & Clean & Horizontal \\
\hline $\begin{array}{l}\text { 3. Iron } \\
\text { chisel }\end{array}$ & $2-5$ & Flat & $3-5$ & $2-3$ & Clean & $\begin{array}{l}\text { Oblique to } \\
\text { vertical }\end{array}$ \\
\hline $\begin{array}{l}\text { 4. Bone } \\
\text { chisel }\end{array}$ & 1.5 & $\begin{array}{l}\text { Deeply } \\
\text { concave }\end{array}$ & 3 & $3-5$ & $\begin{array}{l}\text { Ragged/ } \\
\text { shearing }\end{array}$ & Oblique \\
\hline
\end{tabular}


Table 7. Results of Virginia Lake Stake 13 toolmark analysis measurements.

\begin{tabular}{|c|c|c|c|c|c|c|c|}
\hline $\begin{array}{l}\text { Mark } \\
\#\end{array}$ & $\begin{array}{l}\text { I. Curvature } \\
\text { of cutting } \\
\text { edge }(\mathrm{cm})\end{array}$ & $\begin{array}{l}\text { II. Shape } \\
\text { of } x- \\
\text { section } \\
\text { (cm) }\end{array}$ & $\begin{array}{l}\text { III. Average } \\
\text { length of } \\
\text { cutting edge } \\
\text { (cm) }\end{array}$ & $\begin{array}{l}\text { IV. } \\
\text { Average } \\
\text { max } \\
\text { penetrati } \\
\text { on }(\mathrm{cm}) \\
\end{array}$ & $\begin{array}{l}\text { V. } \\
\text { Neatness } \\
\text { of cut* }\end{array}$ & $\begin{array}{l}\text { VI. } \\
\text { Angle } \\
\text { of } \\
\text { attack }\end{array}$ & $\begin{array}{l}\text { VII. Edge } \\
\text { angle }\end{array}$ \\
\hline 1 & 16.33 & Concave & 3.84 & 3.59 & Clean & Oblique & Unknown \\
\hline 2 & Unknown & $\begin{array}{l}\text { Slightly } \\
\text { concave }\end{array}$ & 4.13 & 1.66 & Clean & Oblique & Unknown \\
\hline 3 & Unknown & Unknown & 7.6 & 4.69 & Unknown & Oblique & Unknown \\
\hline 4 & Unknown & Flat & 5.89 & 3 & Unknown & Oblique & Unknown \\
\hline 5 & Unknown & Concave & 6.56 & 5.06 & Unknown & Oblique & Unknown \\
\hline $\begin{array}{l}\text { Total } \\
\text { average: }\end{array}$ & 16.3 & $\begin{array}{l}\text { Concave to } \\
\text { lat }\end{array}$ & 5.6 & 3.6 & Clean & Oblique & Unknown \\
\hline
\end{tabular}

*Neatness difficult to discern-degradation has created soft or ragged look to three of the marks that may have not been present at original creation

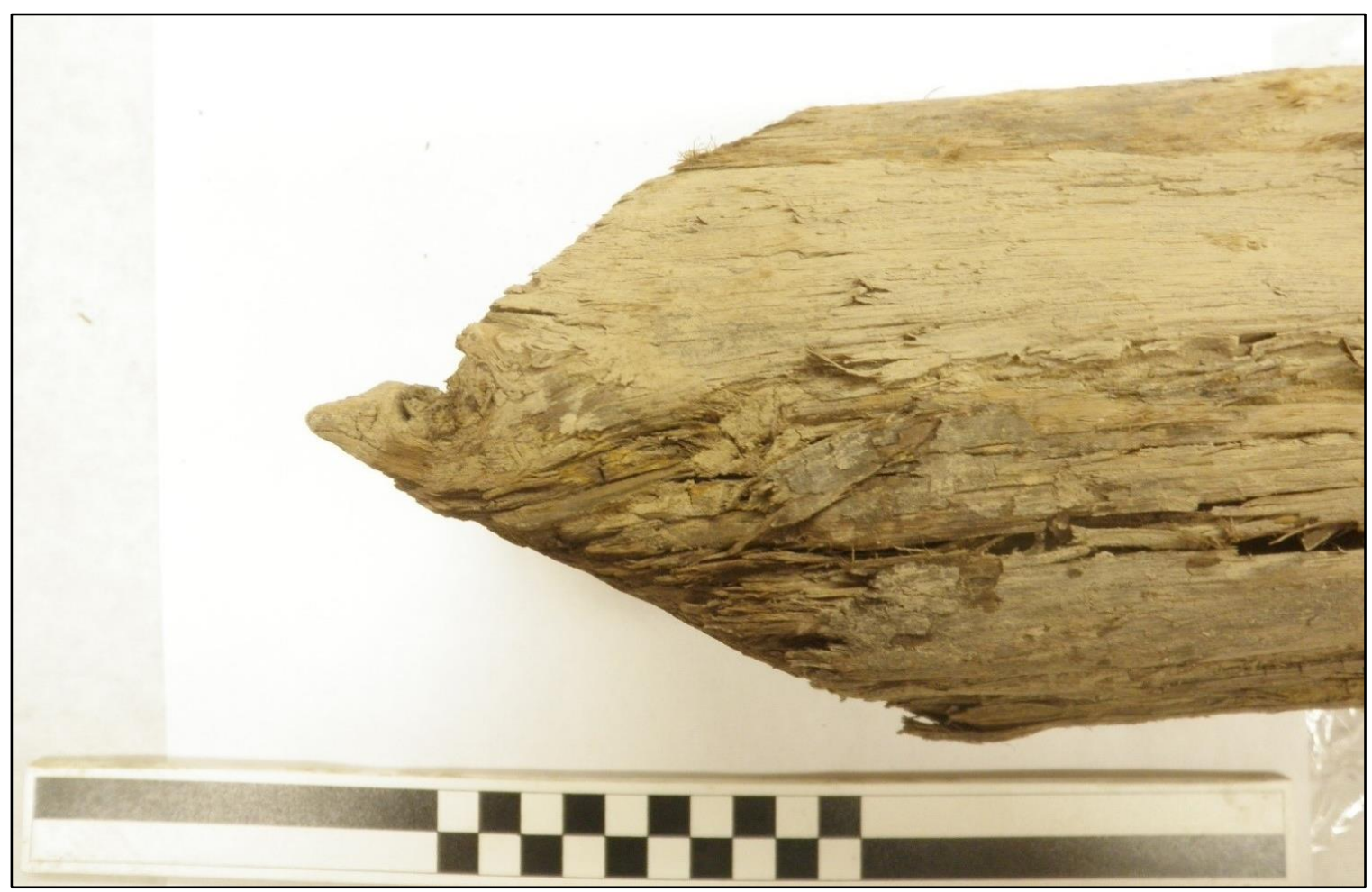

Figure 20. Stake 13, distal end. 


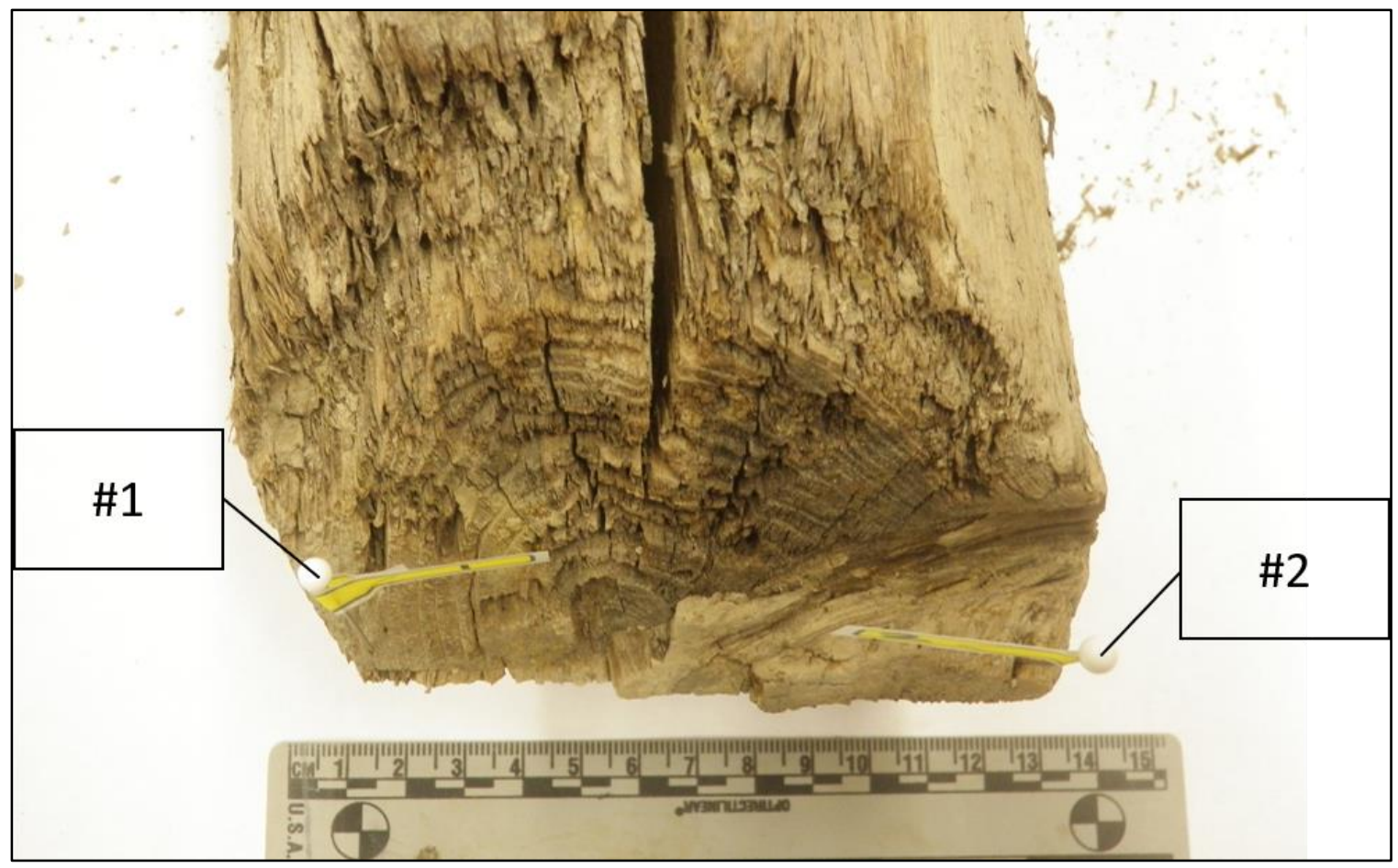

Figure 21. Stake 13, toolmarks 1 and 2 flagged.

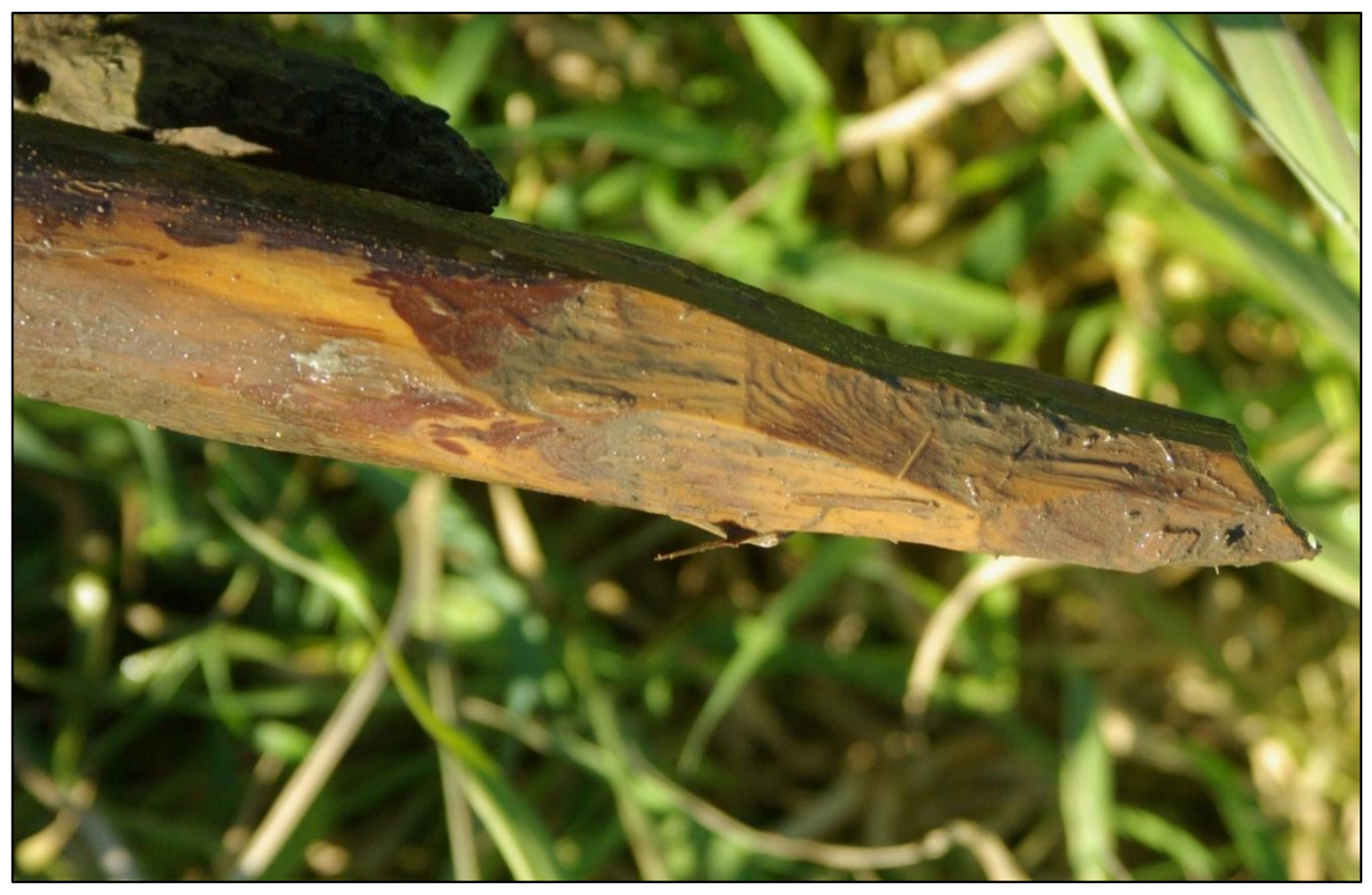

Figure 22. Distal end of Stake 5, image courtesy of local landowner. 


\section{AMS Dating Results}

In total I submitted six wood samples from five stakes and one sediment sample for AMS dating (Table 8). Results are reported in text as calibrated dates. Calibrated AMS results are discussed using the median reported dates, as opposed to expressing the full range (Bronk Ramsey 2001). For example, the sample from Stake 21, which was reported as $72 \pm 27$ uncalibrated radiocarbon years (Table 8), has a $75.8 \%$ probability of falling between 1812 and 1919 CE after calibration, with a median calibrated age of 1854

\section{CE (Table 9).}

Samples that originally returned as "modern" were not calibrated. Despite being reported as "modern" by DirectAMS Labs, these samples cannot be assumed to be modern in age because of the shortfalls of the calibration curve on dates less than 500 years old. For example, an uncalibrated radiocarbon date from the historically well documented and stratified Cathlapotle (45CL1) archaeological site returned an age more than 700 years in the future, an impossibility (Ames and Brown 2018).

Using these methods of calibration, three stakes provide a median age between 1847 and 1854 , falling reliably within the mid-19 $19^{\text {th }}$ century (Table 9). In addition to establishing the median calibrated age for each stake, the model used for this study also produced a range of probability for all dates. The aggregated probability of all modeled calibrated dates suggests that the feature may have dated from between 1760 and 1905 . However, given that the dates all closely align, and the other evidence presented in this document, the median age of mid- $19^{\text {th }}$ century is most likely. Two samples (Stakes 12 
and 2), one of which comprises a stake that contains metal (Stake 12), returned "modern" dates, which were not calibrated (Table 8).

Table 8. Uncalibrated results of AMS analysis

\begin{tabular}{|c|c|c|c|c|}
\hline \multirow[b]{2}{*}{ DirectAMS Code } & \multirow[b]{2}{*}{ Sample Name } & \multirow[b]{2}{*}{$\begin{array}{l}\text { Macrobotanical } \\
\text { Identification }\end{array}$} & \multicolumn{2}{|c|}{ Conventional Age } \\
\hline & & & Mean & $\begin{array}{c}1 \sigma \\
\text { error }\end{array}$ \\
\hline D-AMS 032092 & Stake 12 & Thuja plicata & Modern & - \\
\hline D-AMS 032093 & Stake 21 & Thuja plicata & 72 & 27 \\
\hline D-AMS 032094 & Stake 7 & Thuja plicata & 127 & 26 \\
\hline D-AMS 033449 & Stake 13 & Thuja plicata & 115 & 39 \\
\hline D-AMS 033450 & Stake 13 & Thuja plicata & 95 & 35 \\
\hline D-AMS 033451 & Stake 2 & Thuja plicata & Modern & - \\
\hline D-AMS 033689 & TU2 $125-135 \mathrm{~cm}$ & Sediment (humin) & 1031 & 26 \\
\hline
\end{tabular}

Table 9. Calibrated and modelled wood AMS dating results.

\begin{tabular}{|c|c|c|c|c|c|c|c|c|}
\hline \multirow[t]{2}{*}{ Name } & \multirow[b]{2}{*}{ From } & \multicolumn{4}{|c|}{ Modelled (BC/AD) } & \multicolumn{3}{|c|}{$\begin{array}{l}\text { Indices } \\
\text { Amodel }=\mathbf{9 9 . 2} \\
\text { Aoverall=100 }\end{array}$} \\
\hline & & To & $\%$ & M & $\mathbf{m}$ & Acomb & A & $\mathbf{C}$ \\
\hline Start Boundary & 1308 & 1919 & 95.40 & 1734 & 1777 & & & 98.10 \\
\hline Sum & & & & 1832 & 1850 & & & 99.70 \\
\hline R_combine (Stake 13) & 1688 & 1928 & 95.40 & 1831 & 1849 & & 102.80 & 99.60 \\
\hline 2 R_Date (Stake 21) & 1695 & 1919 & 95.40 & 1835 & 1854 & & 95.60 & 99.60 \\
\hline 3 R Date (Stake 7) & 1681 & 1939 & 95.40 & 1829 & 1847 & & 101.80 & 99.50 \\
\hline End Boundary & 1697 & 2293 & 95.50 & 1925 & 1915 & & & 97.70 \\
\hline $\begin{array}{l}M=\text { mean } \\
\mathrm{m}=\text { median } \\
\text { Acomb }=\text { combination } \\
\mathrm{A}=\text { individual agreeme } \\
\mathrm{C}=\text { Convergence Integr }\end{array}$ & $\begin{array}{l}\text { reement } \\
\text { dices }\end{array}$ & dices & & & & & & \\
\hline
\end{tabular}

\section{AMS Dating of Humin Fraction and Lake Formation}

As discussed above, during deep auguring (SP2, SP3, TU1, and TU2), we encountered a fine to medium grained sandy matrix, indicative of a higher energy 
depositional environment, and a highly organic fibrous peat-like matrix. The peat-like matrix indicates a lower energy depositional environment. As discussed earlier, the development of peat may indicate the transition of the water body from an active side channel of the Multnomah, into a lake.

Results of Humin fraction dating of the peat sample returned a calibrated date of between 969 and 1035 CE (925-981 BP). This date suggests that Virginia Lake has been separate from the main Multnomah Channel, for at least the last approximately 1000 years.

\section{$\underline{\text { Macrobotanical Identification Results }}$}

PAST laboratory identified all five stake samples as western red cedar (Thuja plicata). This identification is based on the presence of tracheids with 'bordered pits in 12 rows on the radial wall, taxioid cross-field pits, uniseriate rays measuring $1-12+$ cells in height, and the absence of resin canals" (Appendix D).

\subsection{Inter-Site Comparisons}

I compared characteristics of the Virginia Lake feature to four other sites with wood stakes on the Lower Columbia (Figure 23), focusing on stake dimensions, function, associated assemblage, age, and cultural affiliation. The sites were selected based on the location, relative completeness of reporting, availability of data and high-quality images. However, even with the high quality of reporting, a lack of standardization in recording and reporting wood stake features makes rigorous comparisons difficult. Depending on 
the scope of the work and level of data collection in the field, raw data was often not reported, constraining comparisons to reported averages.

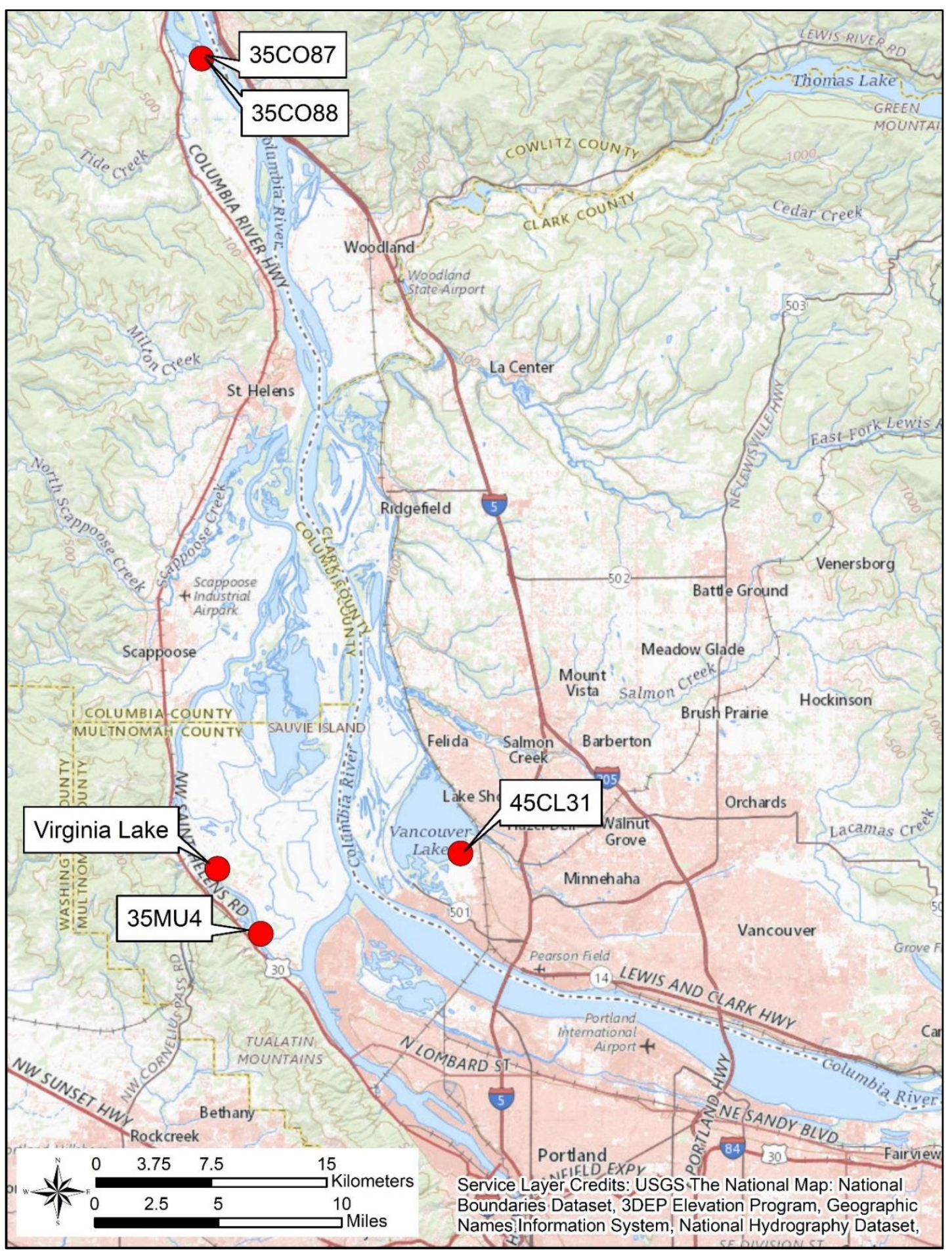

Figure 23. Location map of regional comparison sites 


\section{$\underline{45 \text { CL31 }}$}

$45 \mathrm{Cl} 31$ is a multicomponent archaeological site located on the southeastern edge of Vancouver Lake, Washington, positioned directly east of Sauvie Island (Figure 23). The site is situated near where Burnt Bridge Creek enters the lake, and adjacent to a relic slough (now pond) that likely merged with the lake in high water, creating a bay-like environment (Wessen 1983). Vancouver Lake was once subject to drastic seasonal fluctuations in water level due to seasonal and tidal influence, dampened now as a result of flood control (Wessen 1983).

45CL31 was initially recorded in 1972 during a reconnaissance survey of Vancouver Lake's southern shore (Hibbs and Ross 1972). The site was further investigated in 1980 and 1983, in advance of the Vancouver Lake Restoration Project, which primarily consisted of dredging (Wessen 1983). Archaeological methods for the project included 1) background research, 2) inspection of dredge disposal sites, 3) pedestrian survey at $15 \mathrm{~m}$ intervals, 4) monitoring and inspection of dredge spoils, and 5) test excavations of 45CL31 and limited testing of other sites identified in the project vicinity.

Test excavations at 45CL31 include two $65 \mathrm{~m}$ long stratigraphic trenches excavated up to 1.25 meters deep, and an unspecified number of $1 \times 1,1 \times 2$ and $2 \times 2 \mathrm{~m}$ units (Figure 24). Stratigraphic trenches were used to explore site formation and stratigraphic sequence. Test units explored general questions about cultural occupation and individual features. The plow zone was mechanically stripped, after which test units 
were excavated in $20 \mathrm{~cm}$ arbitrary levels. Excavated sediments were screened through 1/4" mesh. Select bulk samples were screened through $1 / 16$ " mesh.

The site has four distinct components spanning approximately 3,400 years, based on five radiocarbon dates (Wessen 1983). There are two historic components and two precontact components, with one of the precontact components continuing into the contact era. The site has a number of features, and an artifact assemblage consisting predominantly of lithic tools, debitage, and fire cracked rock, with limited faunal and floral recovery. The faunal assemblage included terrestrial mammal, and fish. Identified fish were predominately sturgeon (Acipenseridae), sucker (Catostomidae) and minnow (Cyprinidae). Faunal recovery was low, which may be attributed to the relatively large mesh (1/4") used in recovery. Identified features included pits, hearths, post holes, and notably, a wood stake fish weir.

The feature of most relevance to my study is the wood stake weir, located in Area E, which was identified during monitoring, and subsequently excavated (Figure 24). The amount of time spent documenting the weir, and the specific methods of stake documentation, are not reported. However, the total number of stakes and arrangement of the alignment can be verified from the sketch maps. The weir includes 158 stakes, and 120 identified stake holes, which Wessen suggests once held stakes, now decomposed. Wessen (1983) defines stake holes as representing the mold itself, where a vertical element was driven into the ground without the benefit of a pre-excavated hole. 


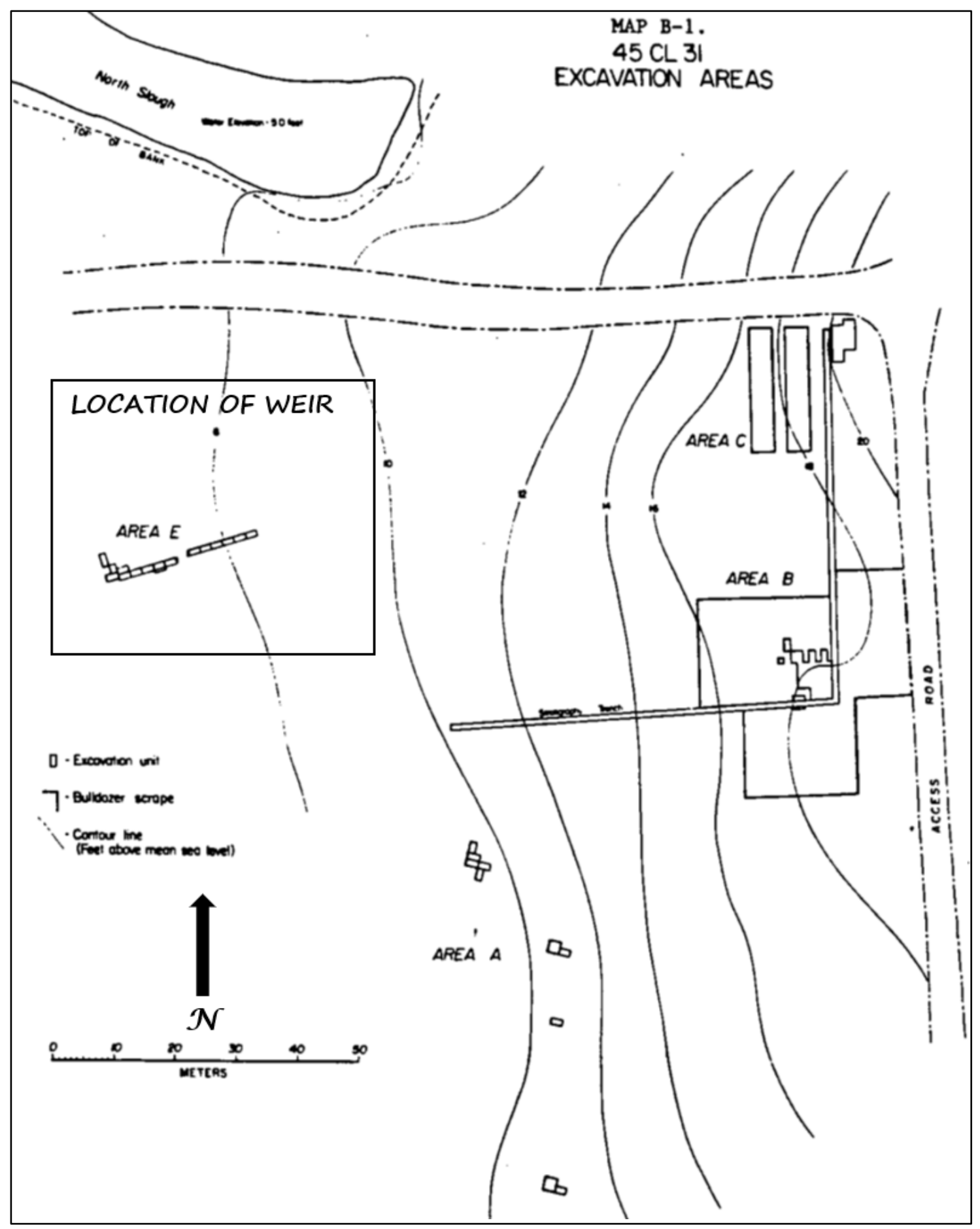

Figure 24. Sketch map of testing at 45CL31. Image adapted from Wessen (1983: B-18).

Stakes extend in a single alignment spanning $45 \mathrm{~m}$, with $15-20 \mathrm{~cm}$ separating each stake. Stakes were split wood, and Wessen reported measurements of 10x12 to $2 \times 6$ 
$\mathrm{cm}$ in diameter and between 17 and $135 \mathrm{~cm}$ in length. However, the number of individual stakes measured is not reported. Based on observations of surface texture, Wessen suggested the stake wood was western red cedar. An unknown number of stakes were removed in entirety, as Wessen describes the distal ends. The distal ends of the stakes were modified to a rough point using what Wessen (1983) believed to be a metal tool, likely an axe (Figure 25). Despite the use of metal tools, Wessen suggests that the feature is an Indigenous feature, not Euro-American (Wessen 1983). He makes this assertion based on the associated site assemblage, and because of what group he felt was most likely to have constructed and used a feature of this design.

Stakes in the eastern portion of the feature displayed poorer preservation than those in the west. According to Wessen, this discrepancy in preservation is possibly due to moisture differences, the east being drier, with better drained sediments, emphasizing the importance of water saturation to preservation. Decomposing organic mats were recorded connecting the stakes in the better-preserved western section of the weir. The organic fibers were identified as reeds, long grasses, and sometimes conifer. However, no evidence of weave or other structural organization was observed (Wessen 1983).

The weir structure itself is simple in design. It is formed by two lines of single stakes that meet in the center (Figure 26). Stakes on the eastern line predominately tilt to the south (Figure 27); a small segment of stakes in the west angle northwest. According to Wessen, these angled positions may have acted as a funnel, preventing fish from reentering the lake (Wessen 1983). 


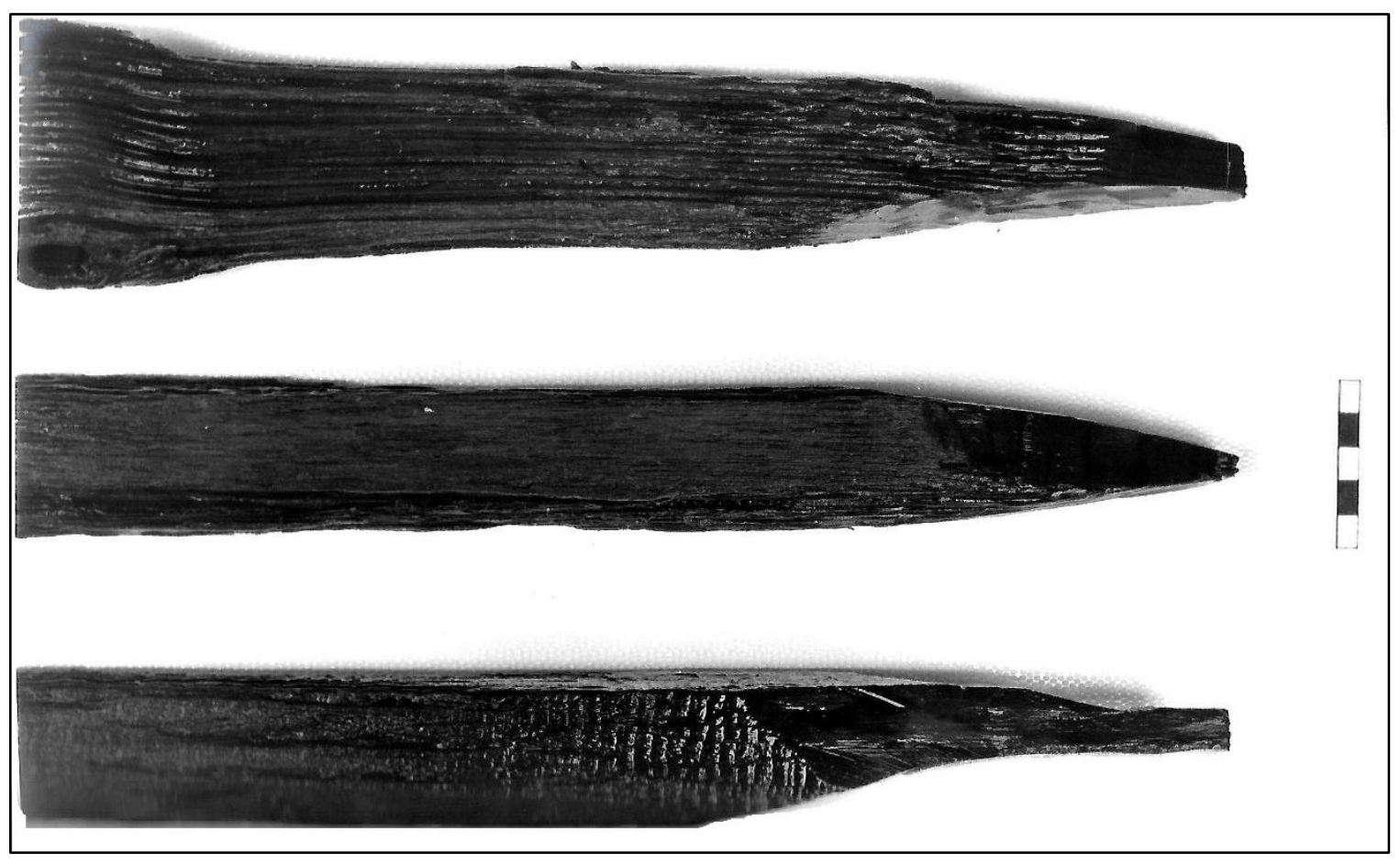

Figure 25. Distal end of stakes from 45CL31 (Wessen 1983).

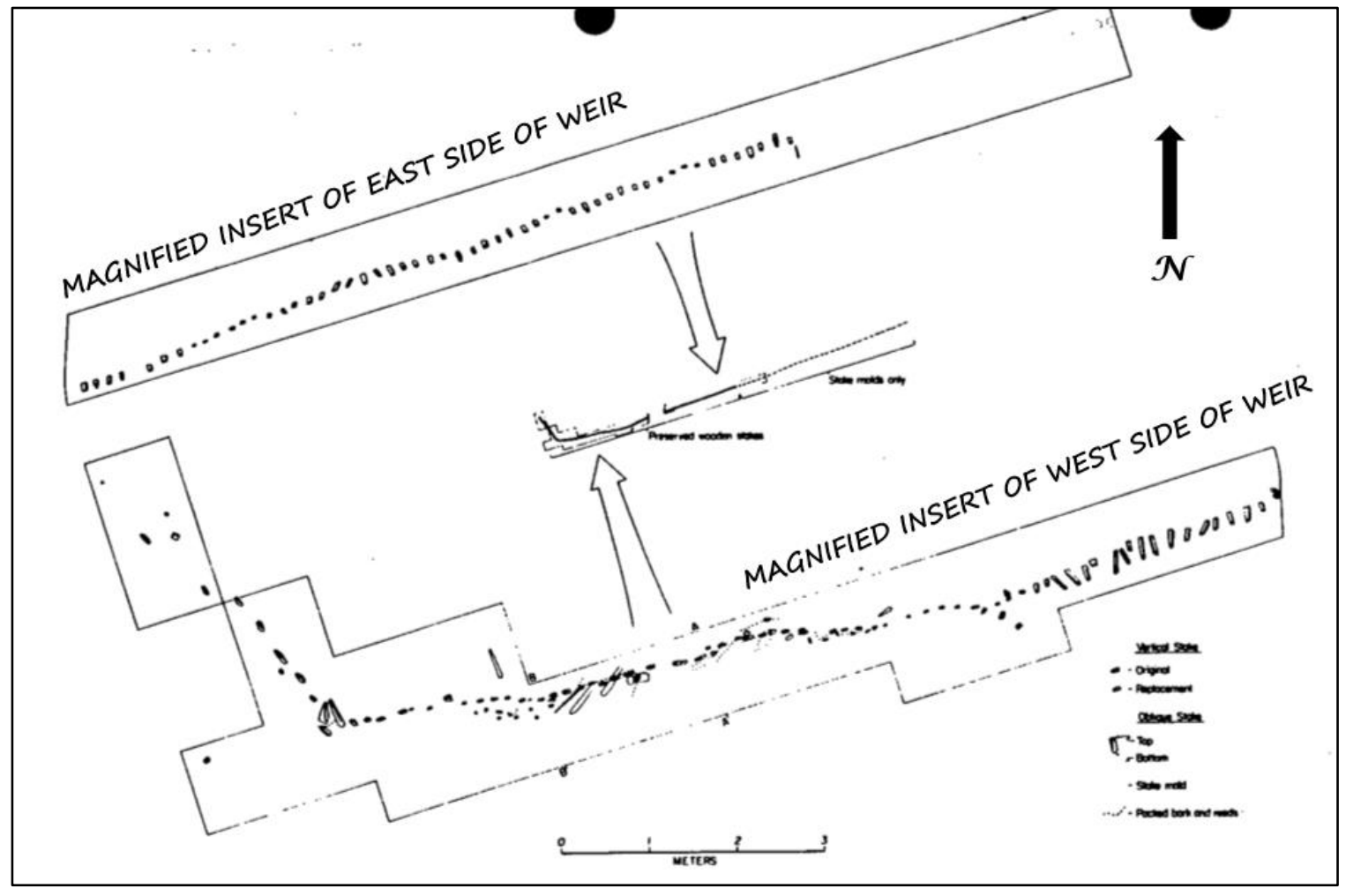

Figure 26. Sketch map of the fish weir at 45CL31 in excavation Area E. Image adapted from Wessen (1983: B-60). 


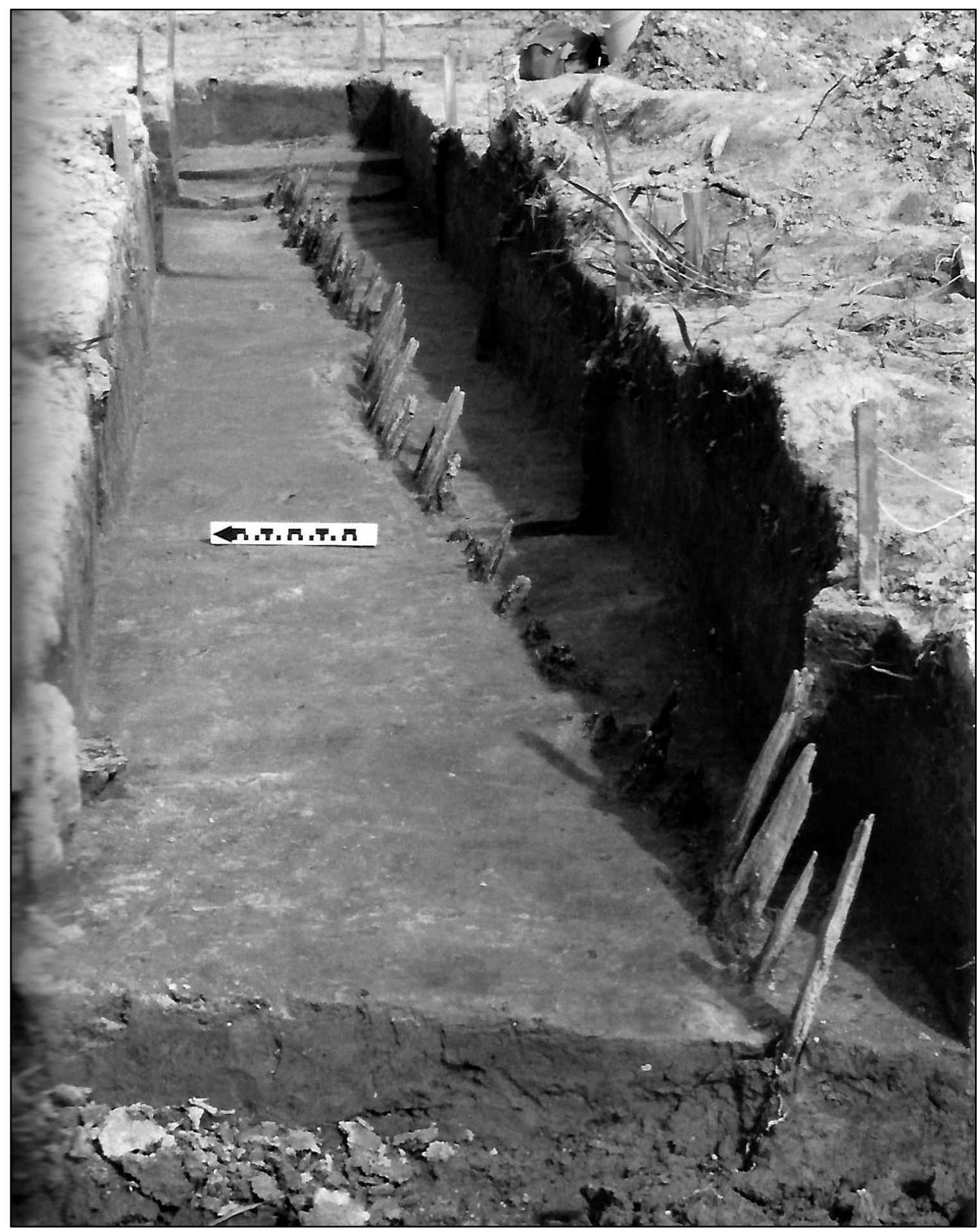

Figure 27. Eastern portion of the 45CL31 Vancouver Lake weir, view east (Wessen 1983). 
An uncalibrated radiocarbon date obtained by Wessen (1983) from material collected from two stakes places the weir at approximately $310 \pm 60 \mathrm{BP}$. Calibration for the purpose of this study returned a $92.9 \%$ probability that the dates fall between 1446 and $1669 \mathrm{CE}$ (Figure 28). It should be noted that the relatively young age of the weir effects the accuracy of the calibration curve. Wessen (1983) speculates that the structure functioned for an extended duration, suggested by evidence of repair. Wessen indicates that evidence of repair includes sections of the feature where a large tree trunk damaged the alignment, and at one point replacement stakes were positioned slightly to the south of the original line.

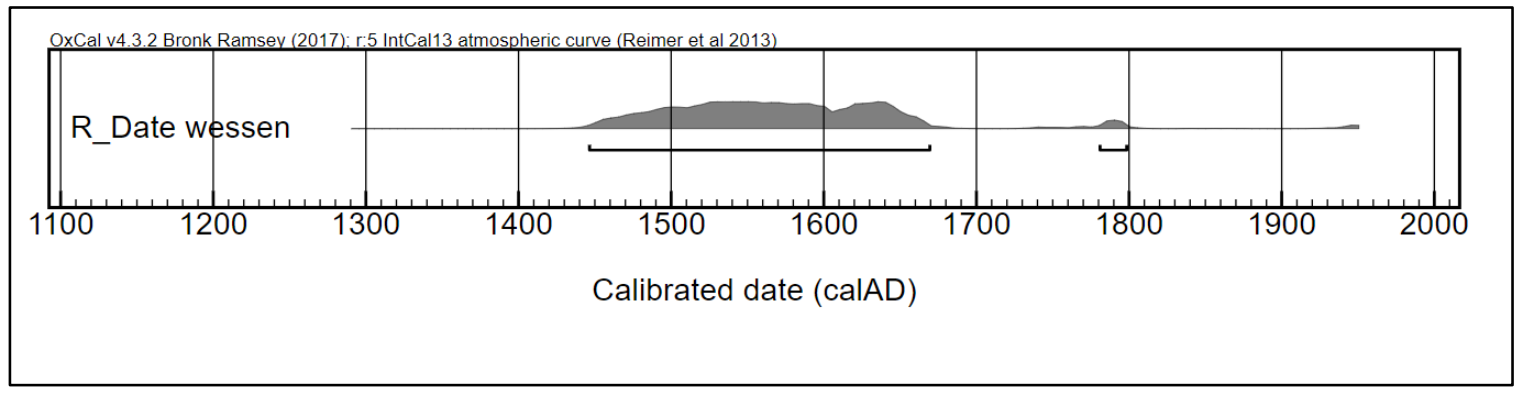

Figure 28. Figure showing the probability distribution of the calibrated age of the 45CL31 weir.

Wessen (1983) suggests that the weir was used to harvest freshwater lake fish, such as the families identified during excavations. He came to this conclusion based on the structure and placement of the weir, and the recovered ichthyofaunal assemblage. However, the majority of fish remains were recovered from a single pit feature in excavation Area C (Figure 24), and are not directly associated with the weir in Area E. The weir is positioned near a pond, believed to be a relic slough that once connected with Vancouver Lake (Figure 26). During high water in winter months fish could travel over 
the structure and into the slough. Conversely, in summer months fish would become trapped as water levels dropped, exposing the weir (Wessen 1983). In this way, the weir at 45CL31 functioned as a barrier much like a tidal fish weir.

\section{$\underline{35 \mathrm{MU} 4}$}

As mentioned in Chapter 2, 35MU4, known colloquially as "Sunken Village", is an extensive precontact archaeological site located on the southwest side of Sauvie Island adjacent to the Multnomah Channel (Figure 23). It has both inundated "wet site" and dry inland components, bisected by a levee (Newman 1991). The wet site component is an acorn leaching and processing site with numerous basket lined pits, wood stakes, and other perishable artifacts.

Sunken Village was originally recorded by Richard Pettigrew in 1973 (Pettigrew 1973). Prior to official recording, the site was locally well known and subject to pervasive looting (Newman 1991; Strong 1959). The site has been intermittently excavated by avocational archaeologists with the Oregon Archaeological Society, and professionally tested in 1987, 1988, 2006 and 2007 (Croes et al. 2007, 2009c; Pettigrew and Lebow 1987; Hibbs and Ellis 1988; Newman 1991). The most extensive excavations were conducted in 2006 and 2007 in the "wet" portion of the site, led by Dale Croes, then of South Puget Sound Community College, Archaeological Investigations Northwest (AINW), and in partnership with The National Institute for Cultural Heritage in Nara, Japan under a grant from the Japan Society of Science.

Testing in 2006 consisted of the excavation of four test units, four geologic cores, one half unit bank exposure, and surface mapping (Figure 30). In 2007, the crew 
excavated two additional cores and mapped additional features. Test units were excavated in $10 \mathrm{~cm}$ arbitrary levels using a combination of traditional and hydraulic techniques. Excavated sediments were screened through nested 1/4" and 1/8" mesh. Geologic coring extended to a maximum of $7.6 \mathrm{~m}$.

The Sunken Village site comprises over 100 recorded acorn leaching pits, 55 wood stakes (Figure 29, Figure 30), fire cracked rock, and numerous wood fiber artifacts (wood chips, split wood, basketry, cedar bark clothing, etc.), lithic debitage, faunal remains, and acorns (Croes et al. 2009b, 2009c). The acorn leaching pits are generally 45$80 \mathrm{~cm}$ in diameter, roughly circular in shape, and lined with western hemlock (Tsuga heterophylla) boughs, which protrude from the ground surface (Croes et al. 2007; Newman 1991). Investigations suggest that the hemlock lining served to separate the acorns from the surrounding sediment while still allowing water to pass, to remove tannins. This lining minimizes labor when eventually removing the acorns from the ground after the leaching process is complete. 


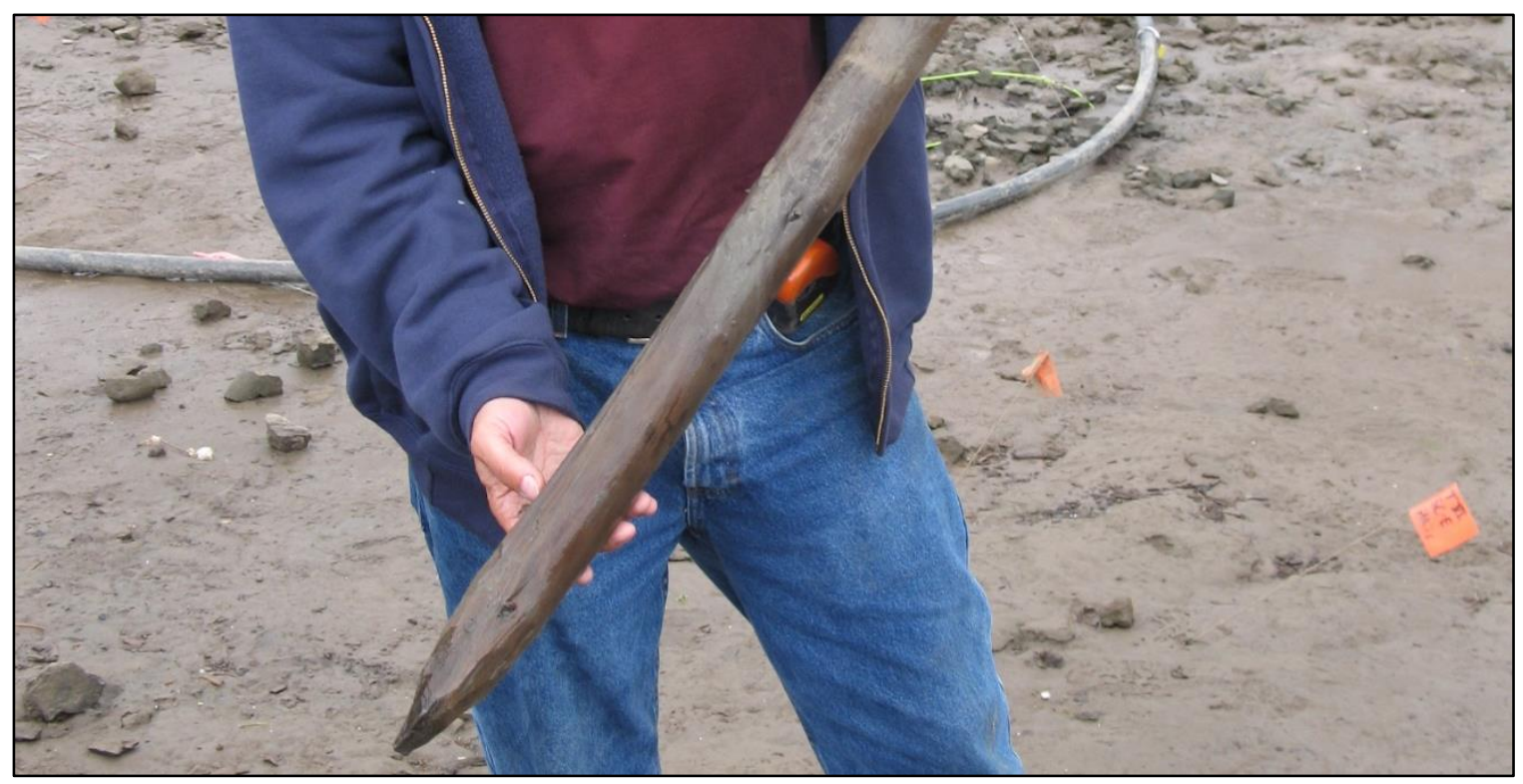

Figure 29. Distal end of removed wood stake from 35MU4. Photo taken September 14, 2006. Image courtesy of Ken Ames.

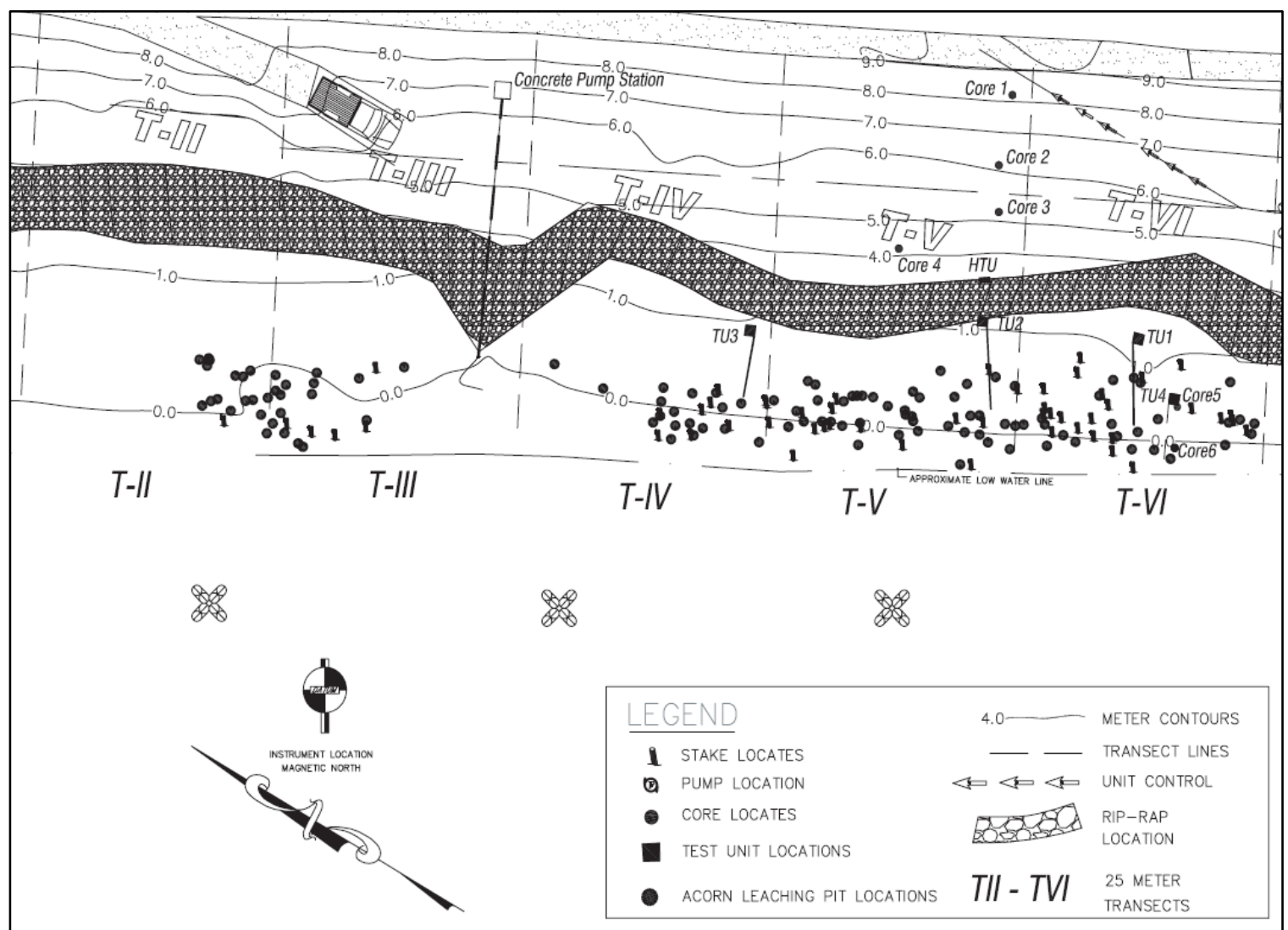

Figure 30. Map of 2006/2007 testing at 35MU4. Map created by Michael Martin (Croes et al. 2009), used here with permission. 
The composition, purpose, and dimensions of the wood stakes at Sunken Village are important elements in my comparison. The two excavated wooden stakes both measure about $1 \mathrm{~m}$ in length. All recorded stakes measure $5 \mathrm{~cm}$ in diameter on average (Croes et al. 2007, 2009c). All 55 stakes were mapped, photographed, drawn, measured, and recorded on an individual in-situ wooden stake form (Croes et al. 2009c). Of the 55 recorded stakes, two were excavated and analyzed (Croes et al. 2009c). Both excavated stakes displayed modification from adzing on the distal end (Figure 29). Macrobotanical cellular analysis of the two stakes indicate one was Noble fir (Abies procera) and the other Sitka spruce (Picea sitchensis). The stakes are always found adjacent to or in conjunction with the leaching pits, and are thought to have either marked the acorn pits to facilitate relocation, or delineated ownership (Croes et al. 2009c).

Four AMS radiocarbon dates were obtained during 2006 and 2007 testing. Samples consisted of charcoal, a hemlock bough lining a pit feature, and vegetation collected from cultural layers encountered during geologic coring (Croes et al. 2009c). Calibrated dates from charcoal and the hemlock bough returned $500 \pm 40$ BP (1410-1490 CE) and 130 $460 \mathrm{BP}$ (1760-1880 CE), respectively (Croes et al. 2009c).

Two AMS dates from coring both returned calibrated dates spanning 0 to $440 \mathrm{BP}$ (1510-1950 CE) (Croes et al. 2009c). The aberrant dates are believed to be the result of "fall in" during coring (Croes et al 2009c). These four dates, in conjunction with five radiocarbon dates from earlier work, indicate an occupation at Sunken Village spanning from approximately the late 1200 s to the late 1800 s, encompassing both the precontact and contact era (Croes et al. 2009c). 


\section{$\underline{35 \mathrm{CO} 87}$}

$35 \mathrm{CO} 87$ consists of an abandoned wood and rebar structure located on the banks of the Columbia River at the mouth of Tide Creek, a meandering distributary channel on the western bank of the Columbia, approximately $40 \mathrm{~km}$ north of Virginia Lake (Figure 23). The site was first recorded in 2018 by archaeologist Anna Neuzil of the Bonneville Power Administration (BPA) during survey in advance of a habitat restoration project. Pedestrian survey was conducted at 5-10 m intervals. No subsurface testing was conducted at the site.

Neuzil (2018) estimated that there are hundreds of individual pilings and horizontal timbers within the site, most of which were not documented due to the limits of the project area and inundation (see Figure 31). One row of wood pilings begins on the bank and extends into the shallows of the Columbia River (Figure 31). As such, some were not accessible for detailed study at the time of initial recording. The pilings are oriented northeast/southwest and are laid out in a geometric pattern. Some are horizontal, while others stand vertically (Figure 31). The wood is very degraded and rebar is present in some of the timbers, possibly used as an anchor (see Figure 31). Neuzil measured an unknown number of accessible individual pilings. These pilings measured between 5 and $12 \mathrm{~m}$ (16.4-39.4 ft) long, and up to $40.6 \mathrm{~cm}$ (1.4 ft) in diameter, although Neuzil noted that erosion has likely affected the shape (Neuzil 2018). 


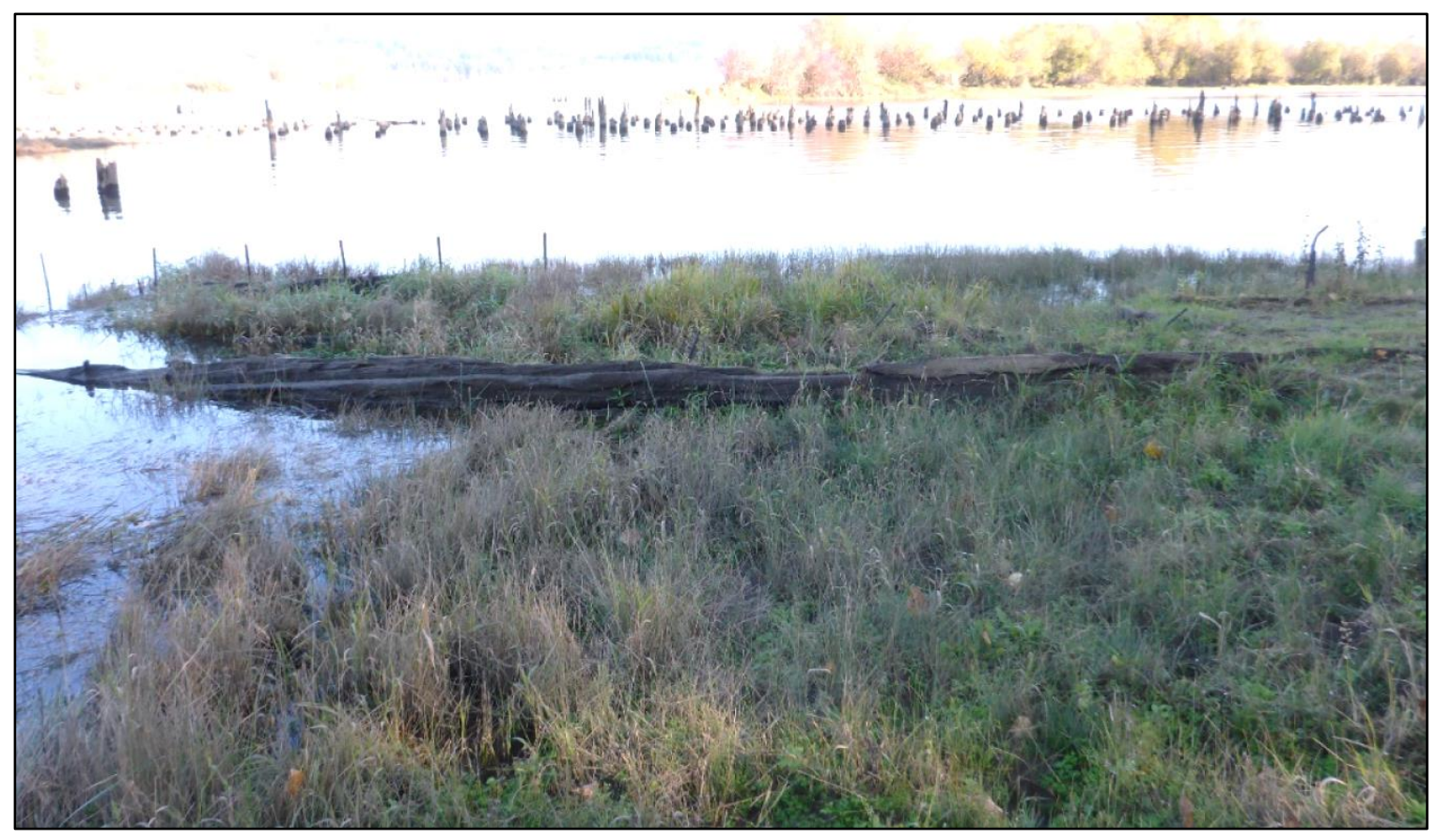

Figure 31. Overview of 35CO87, recorded horizonal timbers and rebar from 35CO87 in foreground, unrecorded pilings in background. View southeast (Neuzil 2018).

The function and age of $35 \mathrm{CO} 87$ are alluded to in historic documents. A sawmill and a boom operated by the Tide Creek Boom and Dam Company existed at the mouth of Tide Creek in 1892 (Neuzil 2018). The company was incorporated in 1889, which places a limiting age on the structure. Aerial imagery from 1929 suggests the structure was present and still in use at that time. The last record of the structure, prior to Neuzil's work, is on the 1954 USGS 7.5 min Deer Island topographic map. Artifacts were not found in association with the site (Neuzil 2018).

Based on these records, Neuzil links $35 \mathrm{CO} 87$ with historic logging activities. It is most likely a boom dam, or other structure used to guide or hold logs at the mouth of Tide Creek. The site was in use from the 1890s to as late as the 1950s (Neuzil 2018). 


\section{$\underline{35 \mathrm{CO} 88}$}

$35 \mathrm{CO} 88$ is an historic causeway located on the west bank of the Columbia River near the south shore, approximately $1.2 \mathrm{~km}$ upriver from $35 \mathrm{CO} 87$. The site was originally recorded by BPA in 2018 during survey in advance of a habitat restoration project (Neuzil 2018). However, its existence had been previously noted during research of a nearby historic homestead, which Neuzil (2018) suggested it is likely associated with. Field methods included pedestrian survey and excavation of three subsurface shovel probes (Neuzil 2018).

Historic images indicate that the causeway extended from Highway 30 to an historic farmstead, and was made almost entirely of wood, with support pilings placed in pairs every six feet. The causeway as it stands today consists of seven wood pilings, clustered in two groups. The first group of four wood pilings stands approximately $3.6 \mathrm{~m}$ (12 feet) above the ground surface and 30.4 to $35.6 \mathrm{~cm}$ (12 to 14 inches) in diameter (Figure 32). The second cluster of three pilings is located about $300 \mathrm{~m}$ to the east and stands between one and three feet tall. However, it is unknown if these pilings are associated with the original causeway. Metal spikes are noted on the pilings' upper surface. These spikes were possibly used to secure cross supports (Neuzil 2018). 


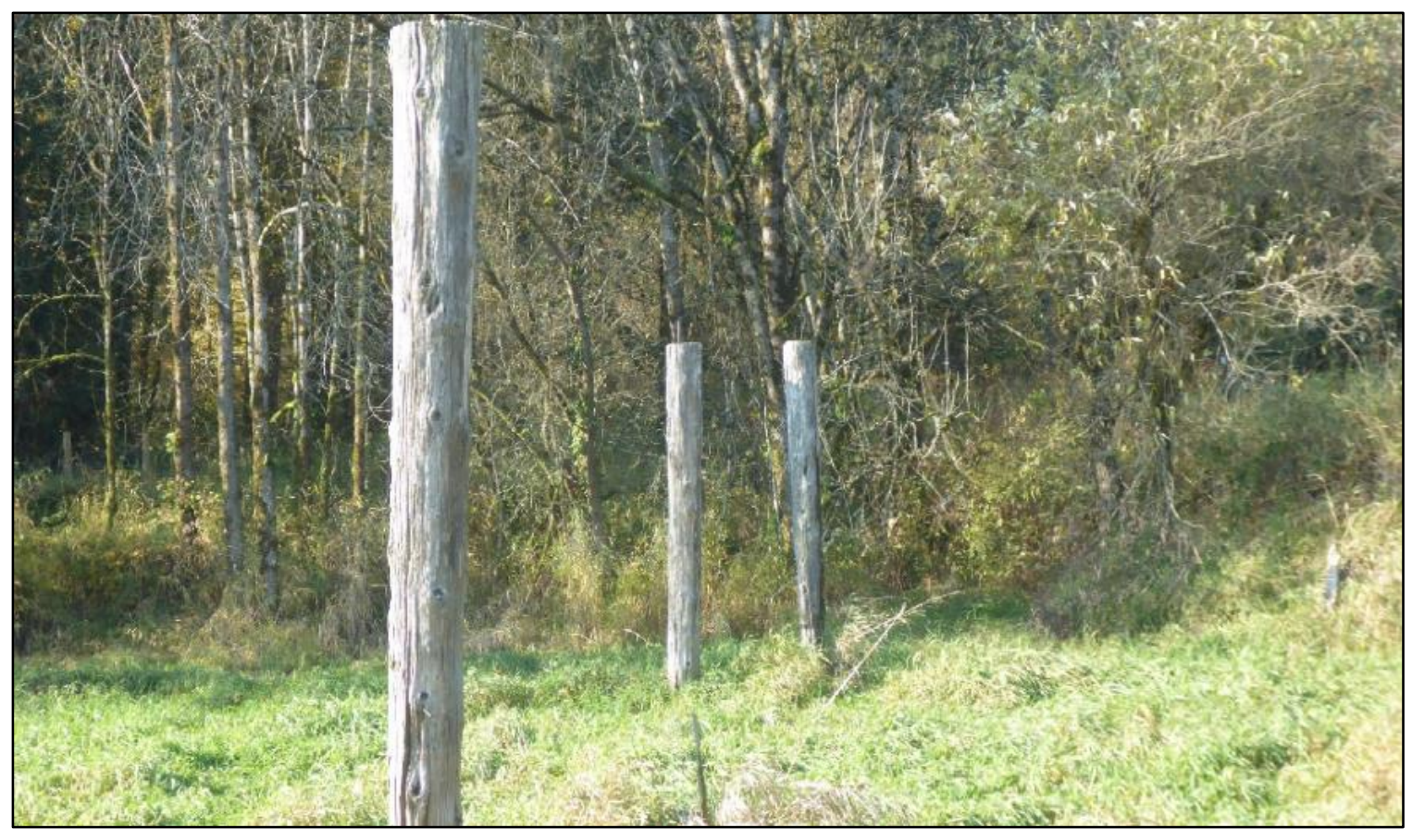

Figure 32. 35CO88, first group of pilings, view west (Neuzil 2018).

According to Neuzil, the causeway was likely used to provide access from

Highway 30 to the farmstead prior to levee construction, when the area would have been frequently flooded by the Columbia. Historic images and maps suggest construction of the causeway occurred by or before the 1920s. The structure was no longer in use by the late 1940s, which aligns with the construction of the Deer Island Levee. The levee lessened flooding and decreased the need for a raised causeway for access (Neuzil 2018; Oliver 2017). 
Table 10. Inter-site comparison of Lower Columbia wood stake sites.

\begin{tabular}{|c|c|c|c|c|c|c|c|c|c|}
\hline Site & $\begin{array}{l}\text { Average } \\
\text { Stake } \\
\text { Diam. } \\
(\mathrm{cm})\end{array}$ & $\begin{array}{l}\text { Stake } \\
\text { Length } \\
(\mathrm{m})\end{array}$ & $\begin{array}{l}\text { Spacing } \\
(\mathrm{cm})^{* * * *}\end{array}$ & $\begin{array}{l}\text { \# of } \\
\text { Stakes }\end{array}$ & Function & $\begin{array}{l}\text { Age } \\
(\mathrm{CE} / \\
\text { BCE) }\end{array}$ & $\begin{array}{l}\text { Dating } \\
\text { Method } \\
*\end{array}$ & $\begin{array}{l}\text { Cultural } \\
\text { Affiliation }\end{array}$ & Comments \\
\hline $35 \mathrm{CO} 87$ & 40.6 & $5-12$ & - & $200+$ & $\begin{array}{l}\text { Timber } \\
\text { industry }\end{array}$ & $\begin{array}{l}1890- \\
1950\end{array}$ & $\begin{array}{l}\text { His toric } \\
\text { records }\end{array}$ & $\begin{array}{l}\text { Euro- } \\
\text { American }\end{array}$ & $\begin{array}{l}\text { Much of the site extends outside of the } \\
\text { project area and was not recorded- } \\
\text { possibly up to } 1000 \text { individual wood } \\
\text { pilings. Few as sociated artifacts; rebar. }\end{array}$ \\
\hline $35 \mathrm{CO} 88$ & $30.4-35.6$ & 3.6 & 180 & 7 & Causeway & $\begin{array}{l}\text { Pre } \\
1920 s- \\
c .1940\end{array}$ & $\begin{array}{l}\text { Historic } \\
\text { records }\end{array}$ & $\begin{array}{l}\text { Euro- } \\
\text { American }\end{array}$ & $\begin{array}{l}\text { Bark removed from wood posts. } \\
\text { Likely associated with nearby historic } \\
\text { farmstead. Few as sociated artifacts; } \\
\text { metal spikes. }\end{array}$ \\
\hline 35MU4 & $5-7.3$ & 1 & - & 34 & Pit Marker & $\begin{array}{l}1290- \\
1820\end{array}$ & $\begin{array}{l}{ }^{14} \mathrm{C} \\
\text { dating }\end{array}$ & $\begin{array}{l}\text { Native } \\
\text { American }\end{array}$ & $\begin{array}{l}\text { Distal end modification (adze); many } \\
\text { as sociated artifacts and features; e.g. } \\
\text { basketry, acorns, lithics, fauna, wood } \\
\text { fiber. Reported date a range of seven } \\
\text { median dates. }\end{array}$ \\
\hline 45CL31 & $\begin{array}{l}10 \times 12 \\
6 \times 2\end{array}$ & $\begin{array}{l}0.17- \\
1.35\end{array}$ & $15-20$ & 158 & Fish weir & $\begin{array}{l}1446- \\
1669\end{array}$ & $\begin{array}{l}{ }^{14} \mathrm{C} \\
\text { dating }\end{array}$ & $\begin{array}{l}\text { Native } \\
\text { American }\end{array}$ & $\begin{array}{l}\text { Distal end modification (metal axe); } \\
\text { associated organic matting Many } \\
\text { artifacts and features in other areas of } \\
\text { site; e.g. post holes, lithics, pits. C14 } \\
\text { date in table from stake. }\end{array}$ \\
\hline $\begin{array}{l}\text { Virginia } \\
\text { Lake }\end{array}$ & $\begin{array}{l}5.6 \text { (in- } \\
\text { situ) } 5.9 \\
\text { including } \\
\text { removed }\end{array}$ & $\begin{array}{l}0.26- \\
1.09\end{array}$ & 250 & 23 & Unknown & $\begin{array}{l}1760- \\
1905^{* *}\end{array}$ & $\begin{array}{l}{ }^{14} \mathrm{C} \\
\text { dating }\end{array}$ & Unknown & $\begin{array}{l}\text { Distal end modification (metal chisel } \\
\text { or axe); no associated } \\
\text { artifacts/features. }\end{array}$ \\
\hline
\end{tabular}

*All ${ }^{14} \mathrm{C}$ dates calibrated for this project were calibrated using OxCal version 4.3 online (Bronk Ramsey 2001). If a date was present from a stake feature, that date was used preferentially over the full range of dates for the site (e.g. 45CL31).

***eported $95 \%$ probability range. Median age of the feature is 1850 .

*** Spacing listed as reported. Virginia Lake spacing is the average, adjusted for obvious aberrant gaps. 
Comparison of the wood stake features and overall age, functions, and cultural affiliation of the sites to the Virginia Lake feature revealed some similarities, but many more differences (Table 10). The Virginia Lake feature's individual stakes have an average maximum diameter of $5.6 \mathrm{~cm}$ measured in-situ, $5.9 \mathrm{~cm}$ including removed stakes, and an average height above ground surface of $25.6 \mathrm{~cm}$ (Table 4). The two removed stakes have an average diameter of $9.02 \mathrm{~cm}$ and total average length of $109 \mathrm{~cm}$.

Conversely, the stakes at historic sites $35 \mathrm{CO} 87$ and $35 \mathrm{CO} 88$ have a maximum average stake diameter over five times larger than those at Virginia Lake (Table 10). Precontact sites 35MU4 and 45CL31, have stake diameters much more consistent in size with Virginia Lake, however, spacing and number of stakes per feature differ substantially between 35MU4, 45CL31 and the Virginia Lake feature, which more closely resembles (but does not match) 35CO88 in this regard. Additionally, both precontact sites had numerous associated artifacts, while the historic sites did not, consistent with the Virginia lake site. 


\section{Chapter 5: Discussion and Conclusions}

In this chapter, I use diverse lines of evidence to address my multiple hypotheses and discuss results of my data analysis in relationship to my initial questions. I also discuss my results in the context of the broader region, directions future work could take, and the implications and limitations of my work.

Wood stake sites, as part of the larger category of "wet sites," are rare in the Lower Columbia. Because of this rarity, the Virginia Lake site provides an opportunity to look at human ecosystem engineering, and more generally landscape modification in backwater wetlands, and how these modifications factor into larger systems of land use and resource optimization in these environments. In order to address these larger topics, it is necessary to answer basic questions of the feature's age (Q1), cultural affiliation (Q2), and function (Q3). As discussed in Chapter 2, under these questions I produced a series of working hypotheses, which my methods aimed to test (Table 1). Because my methods overlap to address multiple hypotheses, I divide my discussion by questions and sub divide by hypotheses.

\subsection{Addressing Hypotheses}

\section{Question 1: What is the Age of the Feature?}

To address the age of the feature, I posed three associated hypotheses (Table 1). The feature is radiocarbon dated to the mid-1800s, with median calibrated dates ranging from $\mathrm{AD} 1847$ to 1854 (Table 8, Table 9), indicating historic era construction (H2). This result negates $\mathrm{H} 1$ (precontact) and $\mathrm{H} 3$ (spanning precontact and historic era). Additionally, metal was identified in two of the stakes (Stakes 10 and 12), and analysis of 
toolmarks on Stake 13 determined that the distal end was modified using metal tools. These results support the idea that the feature was constructed after Euro-American contact.

\section{Question 2: What is the Cultural Affiliation of the Feature?}

Based on the median results of AMS dating, the Virginia Lake feature was constructed during the historic period, but resides within a complex phase of EuroAmerican and Indigenous interaction on Sauvie Island. This phase begins after the epidemics in the 1830s markedly depleted Indigenous communities and Euro-American occupation of Sauvie Island began, but is prior to the larger influx of colonists following the donation land law in the 1850 s.

The metal detector survey indicated that three of the 23 identified stakes contain metal. The metal in two of these stakes could be visually confirmed (Stakes 10 and 12). These metal fragments were small, and appeared vaguely cylindrical, but are highly corroded, and have no other diagnostic characteristics. The metal could not be removed without damaging the stake, so closer examination was not conducted. Curiously, no other associated artifacts or features were found during fieldwork, which included screening sediment from the site through $1 / 8$ " mesh and, later, water screening of bulk samples through finer nested mesh. Metal minimally suggests Euro-American presence, but does not in itself indicate cultural affiliation.

Macrobotanical analysis shows all five stakes from the feature are western red cedar (Thuja plicata) (Appendix D). Red cedar was widely used by both Indigenous and 
Euro-American people across the region (Lang 2013; Stewart 1984). It is a rot resistant wood, making it a valuable material in the damp Pacific Northwest.

Toolmark analysis indicates that the distal end of Stake 13 was modified with a metal tool, most likely a metal chisel, axe, or some combination therein. However, it is well documented that Pacific Northwest Indigenous groups had access to, and used metal tools prior to direct contact and into the historic era (Arcas Associates 1986; Gleeson 1980). Additionally, Wessen (1983) suggests that metal tools were used to shape the stakes in the Vancouver Lake weir, an Indigenous feature (Figure 25).

While the age of the feature is consistent with Euro-American occupation, the feature does not appear on any maps of the area from the $19^{\text {th }}$ and early $20^{\text {th }}$ century (GLO 1854,1862; USGS 1915), despite the presence of unimproved roads, structures, and agricultural fields. Additionally, the mid 1800s were a time of ongoing and complex interaction between Indigenous and Euro-American people in the Lower Columbia. EuroAmerican and Indigenous communities were particularly entangled at this period in regards to labor and trade (Deur 2012). Therefore, it is difficult to differentiate Indigenous (H1) from Euro-American (H2) cultural affiliation based on the results of my analysis.

\section{Question 3: What is the Function of the Feature?}

The function of the Virginia Lake feature $(\mathrm{Q} 3)$ is the question that generates the widest variety of hypotheses (Table 1), which I will discuss individually.

H1: posits that the feature is a fish weir. Fish weirs, also called fish traps, are stationary structures constructed in water that act as a funnel or barrier to direct or trap 
fish for harvesting and can be constructed out of wood, stone, brush, or reeds (Connaway 2007; Elder et al. 2014; Lepofsky and Caldwell 2013). These technologies were an important part of North American Indigenous subsistence, and were used into the historic era (Connaway 2007; Erlandson and Moss 1993; Hewes 1998; Moulton 1991; Rostlund 1952). Some weirs have been dated on the Pacific Coast as far back as 5500 cal BP, however the majority of weirs in the region are much younger, even into the historic period (Byram 2002; Elder et al. 2014; Erlandson and Moss 1993; Moss 2013).

Weirs also played an important role in Indigenous cultural and spiritual practices, especially in the relationship between people and fish (Losey 2010). Weirs were often owned by individuals or families (Byram 2002; Losey 2010), who controlled their use and oversaw the duration and intensity of harvest. Losey (2010) points to ethnographic and traditional knowledge that indicates that weirs were dismantled when not in use, because weirs and fish were sentient, and leaving a weir functional when people were not present to harvest the entrapped fish would offend the fish they depended on for food (Losey 2010). Natural erosional and depositional processes also affect weir preservation and diminish the number of recorded sites (Elder et al. 2014; Moss et al. 1990). This combination of cultural and environmental factors likely explains why many weirs appear incomplete or "non-functional" in the archaeological record, creating difficulty reconstructing how they were used.

Weirs are generally divided into typologies based on location of use. Weirs are most often found in estuaries and riverine environments, although they are sometimes documented in lakes and other backwater environments. In Oregon, weirs are primarily 
documented on the coast, but a smaller number have been recorded farther inland, in backwater environments and up river and into the Plateau (Hewes 1998; Wessen 1983). As previous discussed, Connaway (2007) places weirs into three distinct categories: flowing stream weirs, tidal weirs, and longshore weirs.

Flowing stream weirs were constructed in freshwater streams, and used to direct fish, or obstruct their progress upstream. Usually built in the shape of a " $\mathrm{V}$ " or a straight fence-like alignment spanning the river, these structures direct the fish into a fish trap, or to a narrow opening where they can be easily speared or netted. These kinds of weirs were usually constructed in shallow waters, as deep water or high flow would hamper the construction and regular maintenance that placement in flowing water requires (Connaway 2007; Kroeber and Barrett 1960).

Tidal estuary weirs function by allowing fish to swim over the barrier during high tide, where they become stuck on the outgoing tide when the barrier becomes impassable (Byram 1998; Connaway 2007; Moss et al. 1990). These structures could be left unattended and returned to on an outgoing tide to collect the trapped fish. Although most common in tidal environments, these types of weirs can also function in areas of seasonal water fluctuation, such as the Vancouver Lake weir.

Longshore weirs are constructed in non-tidal inlets, mouths of rivers, on the edges of lakes, or along saltwater shorelines (Connaway 2007). Longshore weirs work by diverting fish that traditionally swim in schools parallel to the bank with a single linear alignment jutting from the bank. Upon encountering this barrier, fish would swim around it into a waiting trap (Connaway 2007). 
If the feature is a weir, its location in a backwater environment off the main river channel is particularly interesting. Weirs are uncommonly recorded in the backwater. However, some of the most common fish species identified in the archaeological record are backwater species from the families Catostomidae and Cyprinidae, often outnumbering salmonids, which are more prominent in ethnographic records (Butler 2004; Butler and Campbell 2004; Butler and Martin 2013; Saleeby 1983). Despite the prevalence of these species in faunal assemblages from the Lower Columbia, including the Vancouver Lake site, there is little mention of Catostomidae and Cyprinidae fishing practices or consumption in current ethnographic and ethnohistoric records (Butler 2004; Butler and Martin 2013; Hunn 1990). Neither Cyprinids or Catostomidae comprise the major fish species described by Lewis and Clark during their time in the region (Butler 2004; Moulten 1991).

While their apparent consumption and abundance are acknowledged, the role backwater fish species played in the regional economy, and the methods indigenous people used to harvest them remain unclear. This raises questions pertaining to the practices and technology, such as weirs, that may have been used in the harvest and cultivation of backwater species to enhance the productivity of this archaeologically prominent fishery, and the ways in which this technology contributes to a broader understanding of these larger systems (Butler 2004; Butler and Martin 2013; Butler and Campbell 2004; Boyd and Hajda 1987; Saleeby 1983).

The Virginia Lake feature, if a weir, would likely have functioned as a longshore weir, or like the Vancouver Lake weir, a variation of a tidal barrier trap. I draw this 
conclusion based on the location and form of the structure. The feature is located in a backwater lake, adjacent to the Multnomah Channel. Today, the lake is separated from the channel by a levee. LiDAR imaging indicates that the lake was once connected to the main channel, and separated as the Multnomah Channel migrated (Figure 11).

Analysis of the lake history, including humin dating of lake sediments during this study, indicates that the lake has been separate from the main channel for at least 1000 years; the feature is not a flowing stream weir. As a linear alignment jutting out from a lake shore into the water, it resembles a longshore weir in location and relative construction. It could have been used to direct fish into a trap that did not preserve, or was removed prior to recording. However, the seasonal nature of the lake suggests that perhaps the Virginia Lake feature may have functioned like the 45CL31 weir, despite obvious discrepancies in form. As described in Chapter 4, Wessen (1983) hypothesized that the weir at 45CL31 functioned like a tidal barrier weir, allowing fish to swim into the slough during high water, and trapping them in the confined area as lake levels dropped.

The age of the Virginia Lake feature does not preclude its function as a weir. As previously mentioned, weirs were used into the historic-era. Connaway (2007) documented 21 historic fish weirs in his survey of Mississippi weir sites. These features were all recorded in rivers, creeks, or sloughs, and encompassed a variety of forms and material types including wood, stone, and wire. Connaway (2007) designated these structures as historic based on the nature of the construction materials, or historic documentation (i.e. the builder is known). 
Documented historic and contact-era weirs on the Oregon Coast and inland confirm the use of these structures in the Pacific Northwest during the period of the Virginia Lake feature (Byram 2002; Erlandson and Moss 1993; Moulton 1991). In Byram's (2002) seminal thesis describing the results of his extensive Oregon coastal weir survey documenting 72 sites, he noted that some of the sites contained milled lumber or were modified with metal tools (e.g. 35LA1103), indicating the sites were used during the historic era. Furthermore, radiocarbon dates place several weir structures post $300 \mathrm{BP}$ (Byram 2002).

As a linear alignment of wood stakes located in a wetland environment, it is tempting to directly assign the function of the Virginia Lake feature to a weir. However, while there are certainly many similarities between the feature and weirs described in the regional literature, there are also several differences, which contribute to uncertainty around this designation. Similarities between the Virginia Lake site and recorded weirs include the size of the stakes (maximum average stake diameter, length), distal end modification, material type, and general linear configuration (Byram 2002; Moss et al. 1990; Schalk and Burtchard 2001; Tveskov and Erlandson 2003; Wessen 1983). Differences are seen in the spacing between the stakes, the lack of associated artifacts, and its location within a backwater lake (Byram 2002; Tveskov and Erlandson 2003; Wessen 1983). These differences do not exclude the feature from functioning as a weir. However, without additional data, they diminish certainty.

The Virginia Lake feature's stakes are spaced approximately $250 \mathrm{~cm}$ apart, with 50 to $77 \mathrm{~cm}$ between pairs. This differs substantially from the 15 to $20 \mathrm{~cm}$ spacing in the 
Vancouver Lake weir, and the narrower spacing most commonly seen on weir stakes observed on the Oregon and Washington coast (Byram 2002; Wessen 1983). Larger spacings are rarer, but not unheard of (Byram 2002; Schalk and Burtchard 2001). However, they would need to be paired with other devices such as lattice panels, brush, or nets to appropriately function (Schalk and Burtchard 2001), neither of which were present or evident at the Virginia Lake site. This lack of lattice, brush or other horizontal in-filling to create a proper "fence" or blocking structure could be the result of poor preservation of these more delicate materials (Byram 2002; Wessen 1983), intentional removal during disuse (Losey 2010); or they may have never been present.

Weirs on the Oregon coast are commonly associated with nearby lithic materials and residential debris (Byram 2002). The Virginia Lake feature, conversely, has a distinct lack of associated artifacts. Intensive pedestrian survey and subsurface testing should have identified these objects if they were present. Based on this evidence (or lack thereof) I conclude that the feature stands alone, although associated sites may be present in the adjacent uplands, which are primarily located on private property.

There has only been one other weir recorded in the Lower Columbia located in a lake, the Vancouver Lake weir (45CL31). While this feature is unique in its inland location, in most other ways, the weir is typical of those found in coastal estuaries in stake diameter, construction, spacing, and associated artifacts. The existence of 45CL31 creates precedent for a weir to exist in Virginia Lake, an environmentally similar location, occupied by people with similar cultural traditions. However, the Virginia Lake feature lacks many of the aforementioned characteristics that indicate 45CL31 was a 
facility designed to catch fish. In summary, the evidence to the support the fish weir hypothesis (H1) for the Virginia Lake feature is weak, but not disproven.

$\mathrm{H} 2$ : states that the feature is the remnants of a causeway or pier. A causeway is defined here as a raised path or track across low or wet ground, and a pier as a platform supported by pillars extending out from shore into a body of water, sometimes used as a landing stage for boats. Interpretation of the results for this hypothesis is complicated, as evidence exists that both supports, and undermines it.

In support of $\mathrm{H} 2$ are the spacing and paired nature of several sets of the stakes. The inter-site comparison indicates that the stake spacing in the linear alignments most closely resembles the historic causeway feature (35CO88). However, the spacing is slightly narrower between causeway stakes at 35CO88 (Table 10). Such wide spacing could compromise the stability of a cross plank or platform structure indicative of a causeway or pier. Because the stakes are paired, it stands to reason that there may have been some kind of cross-plank structure between the alignments, consistent with a pier or causeway. However, there is also no evidence of cross-planks between the stakes observed during fieldwork.

There are six instances of pairing (12 stakes) in the feature, creating two parallel linear alignments. Paired stakes are spaced $50-77 \mathrm{~cm}(20-30$ in) apart. This is a relatively narrow spacing. The spacing limits use and is unexpected for a structure that took a considerable amount of material and effort to build, extending approximately $60 \mathrm{~m}$ (196 ft) into a water body. This narrow spacing would preclude using the feature to cross wagons or other large equipment over the wetland, but not individuals. 
Only two of the 23 identified stakes were confirmed to contain metal, or any kind of possible fastener; this creates difficulty in drawing inferences about the feature's original construction. This is inconsistent with the historic causeway discussed previously, which had multiple metal fastening spikes (Neuzil 2018).

Additionally, as previously discussed in Chapter 4, during fieldwork we measured an approximately $3 \mathrm{~m}$ difference in elevation between the shore and the lakebed at the feature location. This indicates that overbank flooding may occur when water exceeds this depth. Sauvie Island was regularly flooded prior to levee construction, and this flooding would likely submerge the feature, precluding its use as a causeway during high water, when transport across the wetland was most necessary. Furthermore, the feature does not entirely cross the wetland as it stands now, ending before elevation rises again on the western shore. This indicates that the feature did not function as a means to fully cross the lake, as a causeway would.

Moreover, there is no documented road, trail, or other structure illustrated on the property adjacent to the feature in any of the reviewed USGS quadrangles (Figure 33), or GLO maps in the location of the feature (Figure 8) (USGS 1915, 1940, 1956; GLO 1854, 1862 ). The closest track, an "unimproved road," crosses Virginia Lake over $750 \mathrm{~m}$ to the north of the stake feature on the 1915 USGS topographic map (Figure 33). Finally, if the feature is a causeway and the purpose is to cross the wetland, placing it at one of the widest sections of the lake seems impractical, given the additional resources necessary to construct it at this location. Based on this evidence the feature was not likely a causeway, 
used to cross the wetland, but may still have functioned as a pier, extending out into the lake to facilitate access for an unknown purpose. 


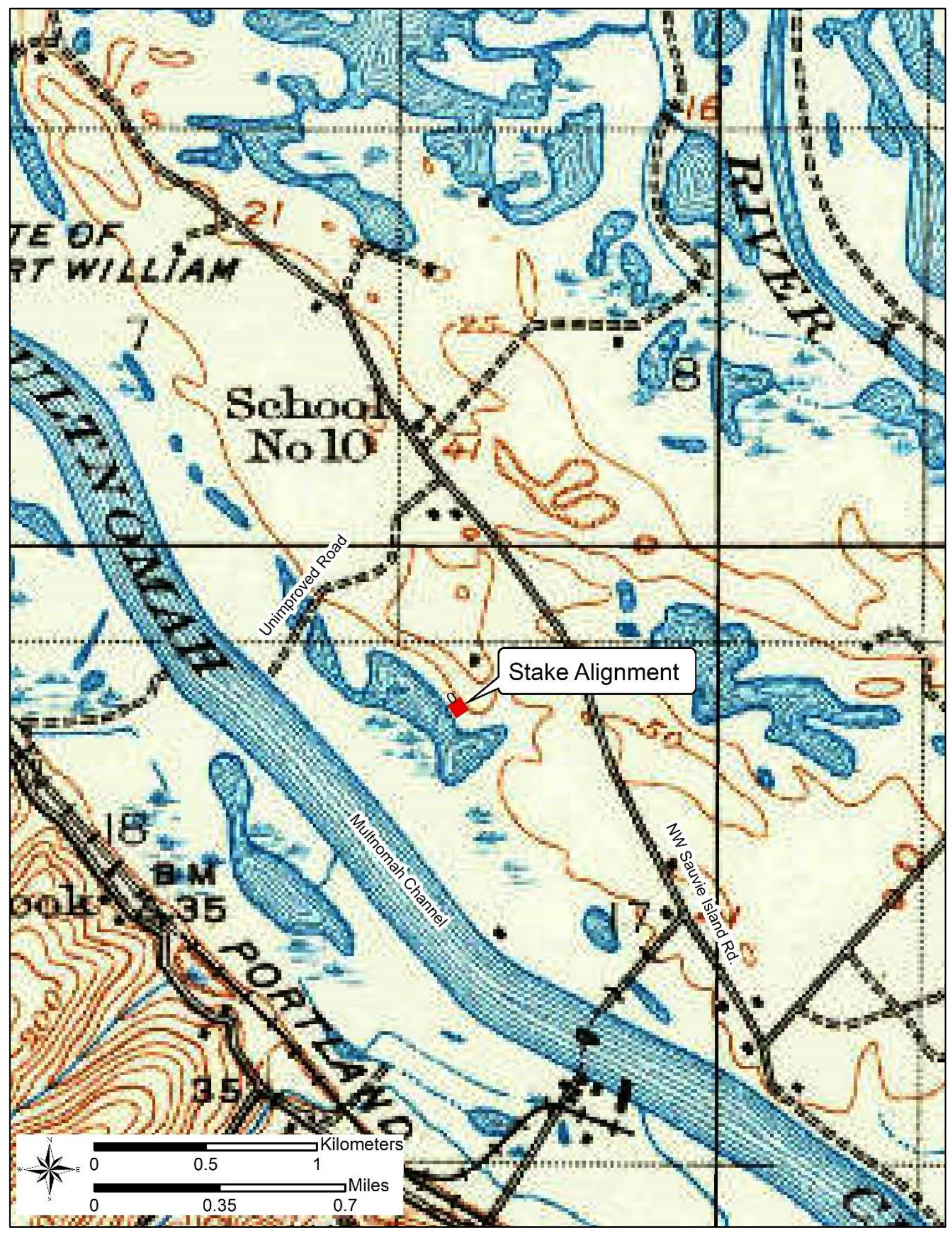

Figure 33. 1915 USGS Hillsboro 7.5 min quadrangle, feature location in red. 
H3: The feature is an historic-era hunting platform/blind. The Lower Columbia was and continues to be part of the Pacific flyway for migrating waterfowl, making it a productive place for waterfowl hunting. It was also a key location in the extensive North American fur trade industry. To address this hypothesis, I compared the feature to modern and historic bird hunting blinds and platforms, and historic beaver traps.

Archival research identified an association between Virginia Lake and historic era duck hunting (Spencer 1950). Ducks were and continue to be locally abundant (Figure 34). Spencer (1950) names the Lake specifically as a premier duck hunting location in his history of Sauvie Island. Based on modern and historic designs, it is likely that a hunting platform/blind for waterfowl, constructed on the lake to allow the hunter to wait unseen above the water, would be square or rectangular.

During survey I recorded what I believe is part of an historic duck blind, constructed with dimensional lumber (Figure 13). The hunting blind/platform consists of four, dimensional lumber posts arranged in an approximate square, which would have supported a flat platform at one time (Figure 13). These remains are consistent with the footprint and construction of a duck blind or hunting platform. The linear alignment of the Virginia Lake stake feature does not fit this form and is inconsistent with historic descriptions and illustrations of bird hunting techniques. Additionally, field survey identified no traps, nets, ammunition, or other artifacts that would link the feature to hunting. Overall, the hunting platform/blind hypothesis is not supported. 


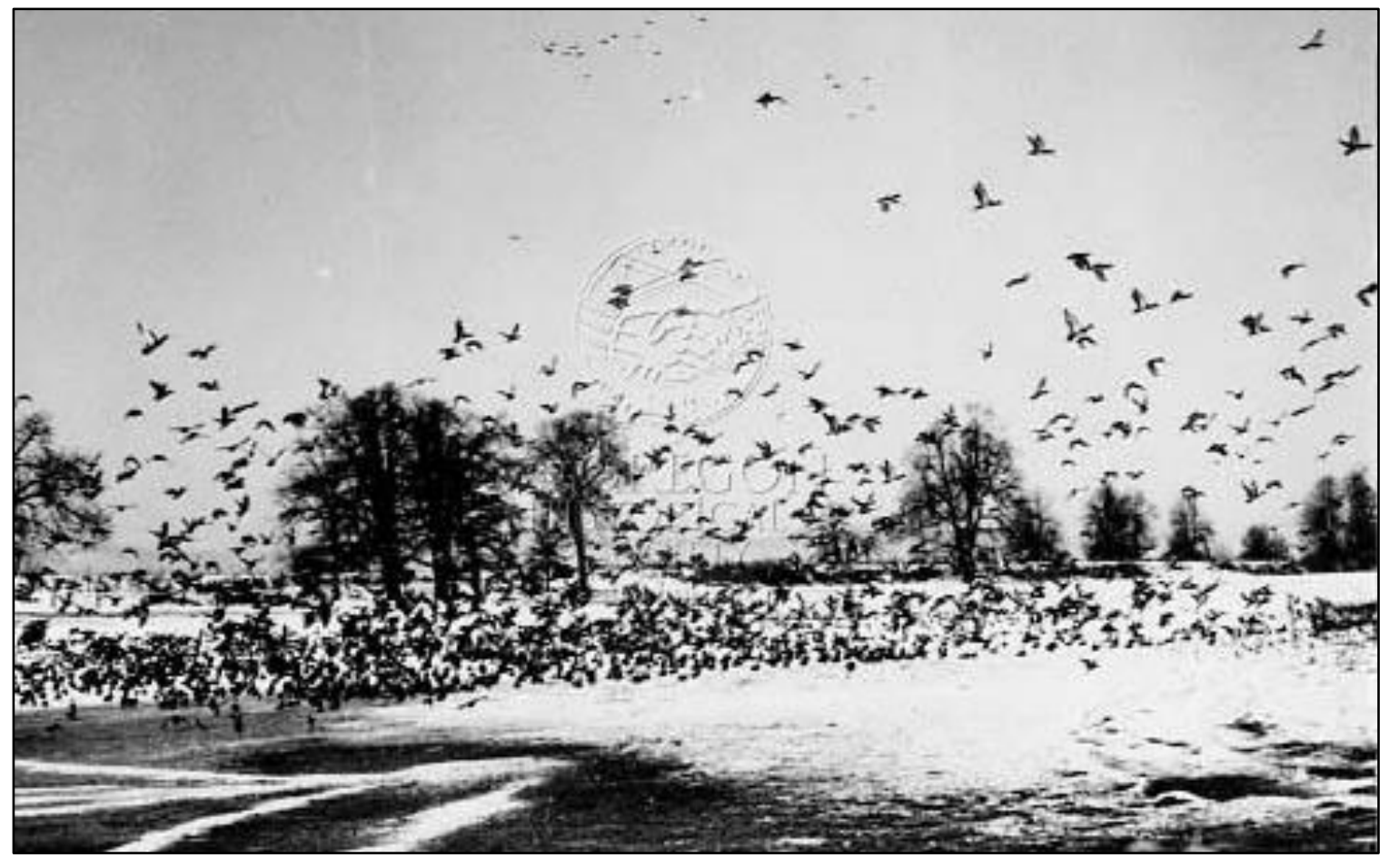

Figure 34. Ducks on Sauvie Island, 1957. Image courtesy of the Oregon Historical Society.

The Lower Columbia was inarguably a key region for beaver trapping, as evidenced by the success of the HBC fur trade at Fort Vancouver. Both Indigenous people and Euro-Americans trapped beaver. Early ethnographies suggest that when beaver was hunted by the Chinook, it was primarily taken using harpoons (Ray 1938), although methods possibly varied.

Hudson Bay era beaver traps were predominately deadfall or metal traps (Figure 35). Deadfall traps kill the animal by crushing. HBC era metal traps used one to three stakes to anchor the trap underwater, where the animal would trigger the trap and then drown (Binus 2005; Proulx 2012). The widely spaced linear alignment of 23 stakes that is the Virginia Lake feature does not match this description. 


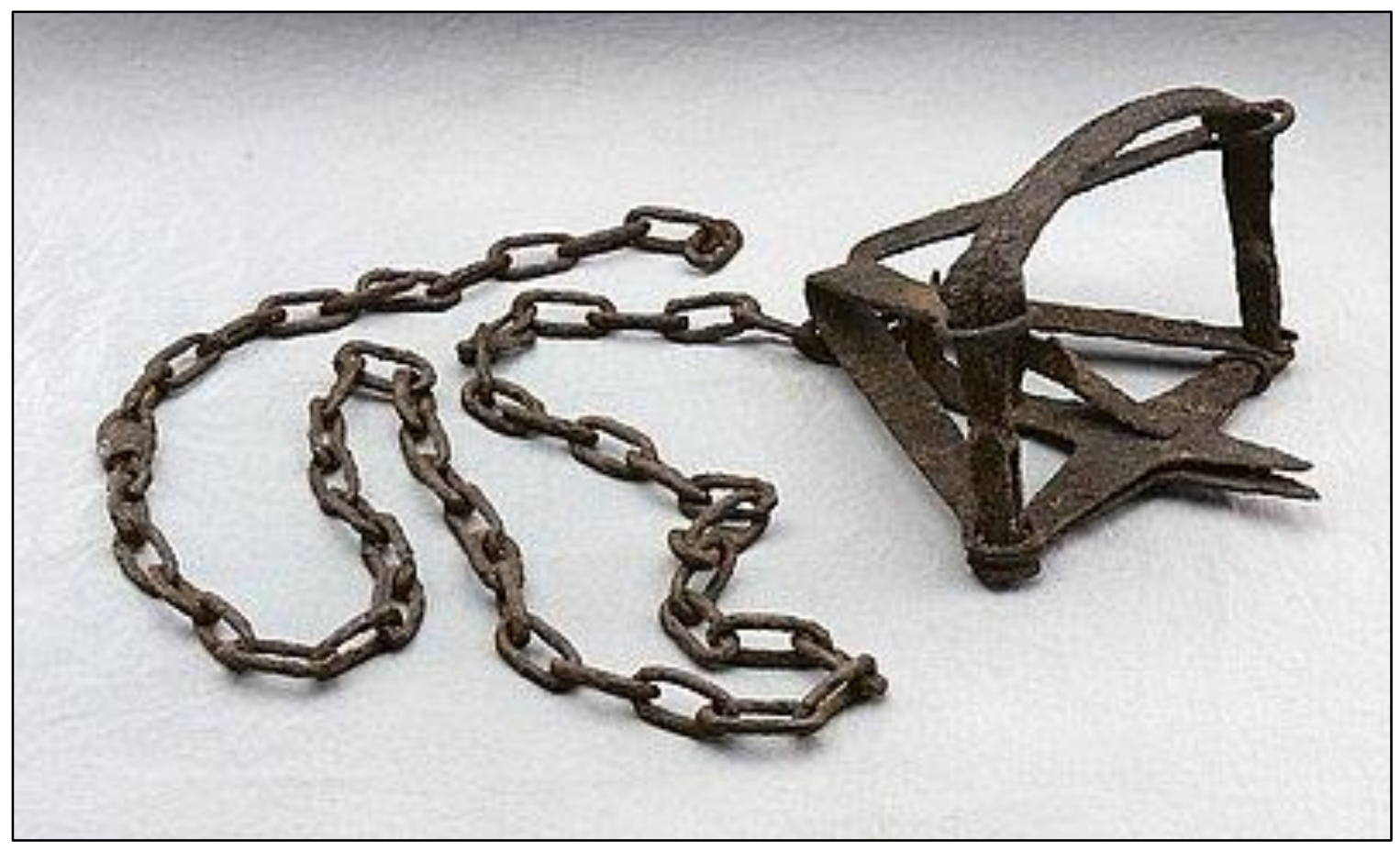

Figure 35. Hudson Bay era metal beaver trap, image courtesy of the Oregon Historical Society.

H4: The feature is a post and line structure used for straightening or storing planks when not in use. Wood was an important resource for Chinookan peoples of the Lower Columbia (Ames and Shepard 2019; Ames et al. 1992). Material was harvested from cedar trees, often in large planks, towed back to the village, and used for a variety of purposes, including canoe building and plankhouse construction and maintenance (Ames and Shepard 2019; Ames et al. 1992; Stewart 1984). Sometimes planks were not straight when harvested or became warped. To straighten the planks to better suit their intended purpose, Indigenous people took damp wood and utilized either a stake and line system to hold the planks straight, or weighted them with large rocks, applying pressure to the planks until they dried (Figure 36) (Stewart 1984). These structures were presumably 
built on land, as the drying process helped straighten the boards. Therefore, it is unlikely that this system is represented in the Virginia Lake feature.

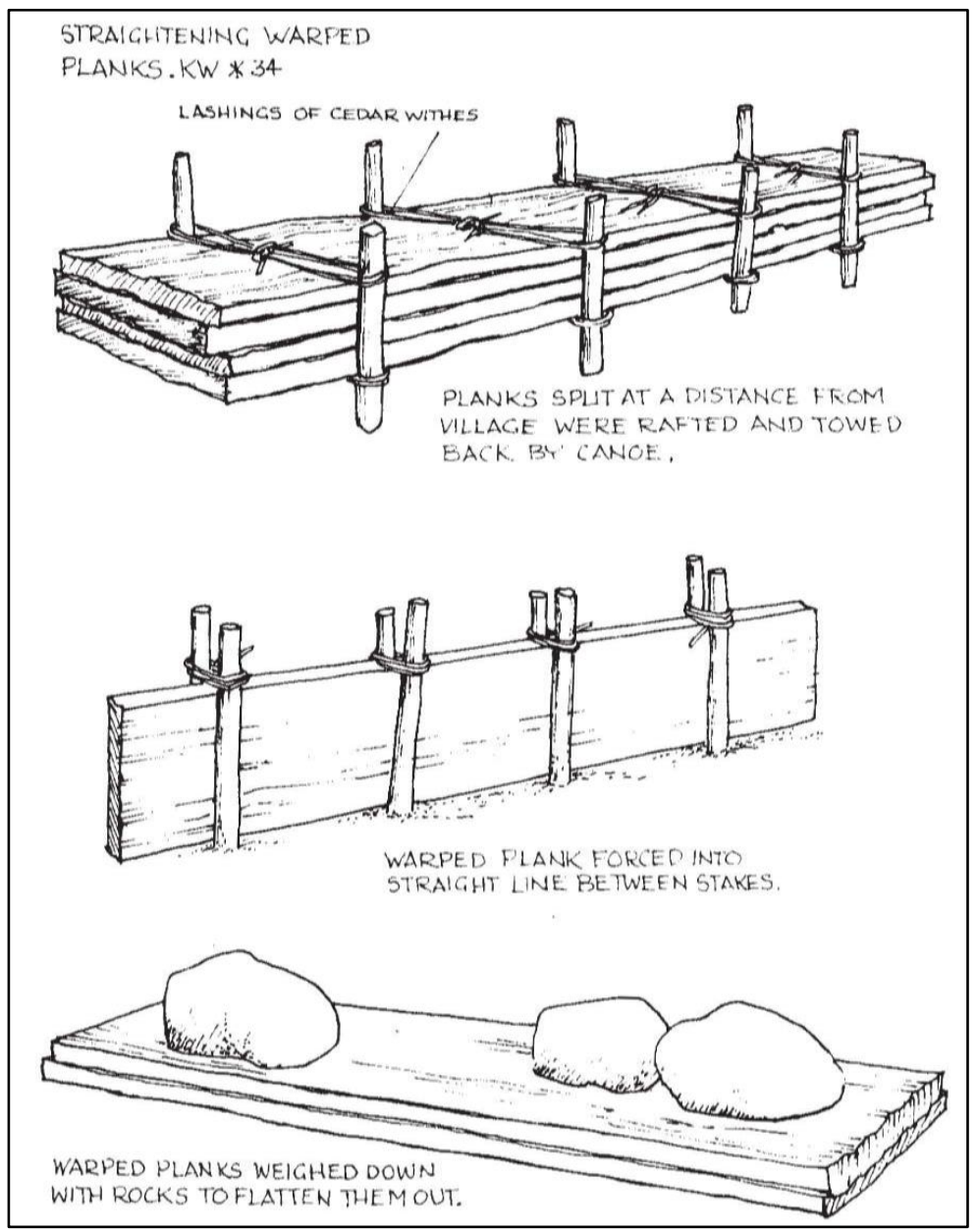

Figure 36. Plank straightening structures. Image used with permission (Stewart 1984:43) Although the plank straightening hypothesis is unlikely, the possibility that the feature was used in plank storage still needs to be considered. People of the Lower Columbia lived in semi-permanent villages in rectangular structures made predominately of cedar planks, remarkably similar in design throughout the Northwest Coast (Ames and Shepard 2019; Ames et al. 1992; Suttles 1990). These structures, known as plankhouses, contained multifamily households that required significant resources and effort to 
construct and maintain (Ames and Shepard 2019; Ames et al. 1992). Plankhouses were built of large wooden post and beam frames, cladded and roofed with wooden planks. The frame stood permanently in a single location, and planks were often moved between frames with seasonal mobility cycles (Ames et al. 1992).

Ames and others have speculated that when not in use, planks were sometimes stored immersed in water. This storage served to preserve the wood and drown any pests that may have taken up residence (Ames et al. 1992). Structures used to store planks in this environment may have emulated the post and line structures used to transport and straighten the planks (Stewart 1984).

There are no known Chinookan villages in the immediate vicinity of the feature (Figure 3). While it is possible that the Virginia Lake feature is the remnants of such a storage system, it seems unlikely that the location of storing planks would be very far removed from a village, as transporting large planks was a resource intensive task. The closest known Chinookan village to the Virginia Lake site is Cathlahnahquiah (gatánaqwaix), located approximately one-mile northwest (Figure 3: \#37). Fort William, and later the HBC dairy, were built on the site of this village, indicating that it had been unequivocally abandoned by the 1830s (Cannif 1981). Furthermore, the Virginia Lake feature is dated to the mid- $19^{\text {th }}$ century, after the most virulent of the epidemics swept through the Lower Columbia, placing intense stress on the Indigenous populations (Boyd 2013; Spencer 1950; Taylor and Hoaglin 1962). This reduction in population likely decreased the need for plankhouses, and possibly eliminated many energy and resource intensive practices, such as the removal, storage, and replacement of planks. Plankhouses 
were a uniquely Indigenous form of housing, and there is no record of Euro-Americans engaging in this practice of storage.

H5: The feature is a property line or fence. As a linear wood stake/post alignment I hypothesized that the feature could represent a simple fence or boundary line. Fieldwork confirmed that part of the feature consist of a series of two widely spaced paired linear stake alignments, not a single line. This is unusual for a fence, which is most commonly a single linear alignment of posts, except in the case of some waddle fences, in which "waddle" or brush is woven between staggered posts, and a variation on the post -and-rail fence where instead of boring holes in posts to insert the horizontal rails, two posts are used and rails are suspended between them (Raup 1947).

Waddle fences were most common in arid portions of the country where wood is scarcer (Raup 1947), not the forested $19^{\text {th }}$ century Northwest. Moreover, a variant of post-and-rail fencing would require a narrow spacing to hold up the rail; frequently the posts were placed in the same post hole (Raup 1947). The $50-77 \mathrm{~cm}$ spacing between paired stakes is quite wide. A double fence alignment, unless there is a specific purpose, would also appear to be a waste of resources.

Fieldwork provided no evidence of joining horizontal planks or wire. I also documented no consistent placement of nails, or other joining materials. Only two stakes were confirmed to contain metal. The bark does not appear to have been removed on the better-preserved stake specimens, nor are they constructed of dimensional lumber.

Archival research and historic map review place the feature outside of both of the nearest properties (DLC 48 and 49) during the 1800s (Figure 8). The feature does not 
follow a property line, nor does it appear to have significantly changed in position to the water, indicating that it was always at least partially submerged. I did not find evidence of a fence or boundary line in or near Virginia Lake in historic imagery or documents. No fence or similar structure is illustrated on USGS or GLO maps from the time period (USGS 1915, GLO 1862, USACE 1929).

In summary, the feature's function is still uncertain, though some hypotheses are less likely than others. In particular, evidence and logic help eliminate the hunting platform/blind (H3), post and line structure for straightening or storing planks (H4), and fence (H5) hypotheses, as well as the causeway (H2, part 1), narrowing the possibilities to either a fish weir (H1), or a pier (H2 part 2).

Question 4: How Does the Feature Relate to Human Ecosystem Engineering in the Wetlands of the Lower Columbia?

The Virginia Lake feature is undeniably an example of human landscape modification in a wetland of the Lower Columbia. However, because of the novel nature of the feature, and because the function and cultural affiliation cannot be determined with certainty, it is difficult to place it within a larger system of human ecosystem engineering. This difficulty stems from a lack of comparable sites, and the ambiguity of the feature itself, two issues which may benefit from additional work in the region. Because the feature's function in uncertain, it is difficult to draw larger implications from my work. Specifically, I could not apply NCT towards understanding the feature, and its larger role in ecosystem engineering on a regional scale, as initially planned. To use NCT as a theoretical framework in understanding how human constructions optimize resources and 
alter the environment to more efficiently meet human needs, I must first understand the function the construction serves in order to identify the need it meets, or the resource it optimizes.

\subsection{Limitations}

I encountered three main limitations in my research: a dearth of comparative sites, a lack of standardization in recording stake sites, and the tendency for relevant reports and summaries of previous work to only exist in so-called grey literature. I identified very few comparable features within the region in my research. Isolated wood features have not received much attention in backwater areas. Many are assumed to be recent, or of Euro-American origin. These assumptions go mostly unchallenged, as in the Pacific Northwest, inland fishing facilities have been little studied. Most fishing facilities have been recorded in riverine or estuarine environments (Byram 2002; Elder et al. 2014), not pluvial, as the Virginia Lake feature.

The lack of standardization in wood stake site recording in the Lower Columbia has created differences in data collection and reporting. For example, at minimum, the number of individual stakes, dimensions, and precise locations should be recorded. Additionally, historic and precontact recording differs widely, increasing the need for standard recoding procedures across site types.

Additionally, my research was hindered initially by the amount of relevant literature that has only been published in contract archaeology reports. Often a reference was listed as "report on file with an agency or company". In older reports, some of these agencies and companies no longer existed under their previous names or forms. 
Furthermore, many older documents have not been digitized, creating issues of access. This highlights a pervasive issue in archaeology surrounding grey literature and its separation and inaccessibility in comparison to academic publishing. This creates knowledge gaps even where research has already been completed, but is otherwise difficult to obtain.

In the end, I did not find any precontact or historic features that closely resembled the Virginia Lake stake alignment in form and construction. This lack of like samples may be the result of inaccessibility of data rather than a true absence, but regardless stymied my ability to compare across sites. This created difficulty in associating the Virginia Lake feature's form and origins, and in placing the feature in a regional context. The Virginia Lake feature is novel, having found no analogous features in my research. Its novelty creates difficulty in placing it in a larger system, or understanding its place among other examples of ecosystem engineering and wetland modification.

\subsection{Broader Values and General Contributions}

As one of the tasks associated with my research design, I created a series of recording protocols surrounding data collection in the field. This creates a standard of comparison, which, if used in the future, will create greater ease in comparison across anthropogenic stake sites, and, more broadly, wetland modifications. This not only has utility for replicability, but also for further differentiating the function and significance of the Virginia Lake feature.

My project provides a clear structure, linking specific questions about a backwater feature to testable hypotheses, and outlining the necessary tasks for addressing them, 
which could be used as a template. This structure lends itself well to future investigations, clearly outlining a multi-faceted approach that uses multiple methods, within a program of Historical Ecology. Creating a template that requires clearly stating research questions, associated hypotheses, and necessary tasks, is also relevant in that it discourages assumptions of origin and function prior to the start of work. Any assumption must be placed within the hypotheses structure and compared equally against the other hypotheses, forcing the researcher to plan for and address multiple possibilities equally. Using this structure, my thesis provides a methodological template for evaluating features associated with wetland landscape modification and exploring the relationship between these modifications and larger systems of ecosystem engineering.

My thesis can facilitate future work by updating and increasing the accessibility of previously unpublished "grey literature" such as the Arcas Associates (1986) toolmark study and the Wessen (1983) excavation report on 45CL31. The Arcas Associates study created a replicable, tested, method for differentiating which tools created specific toolmarks on wood, but had not been previously digitized. In this document I have synthesized the results of the 1986 study, updated the graphics for greater utility, and created an accessible table of the original classifications (see Figure 7, Table 2, Table 5, Table 6).

The Vancouver Lake weir (45CL31), despite its notable size, and unique backwater location, has garnered little attention since Wessen's initial report was published in 1983. As previously discussed, both cultural and natural erosional and depositional processes affect the preservation and subsequent discovery of weir sites 
(Elder et al. 2014). For heritage managers to better plan for, and create research designs capable of identifying these kinds of sites in backwater environments, the few recorded examples need to be highlighted and meaningfully incorporated into further regional synthesis and publications. Researchers cannot adequately test for specific site types, if there is no known precedent for them to exist in a given environment. My thesis highlights backwater wetland cultural constructions in the region, such as the 45CL31 weir, and presents methods for better identification and recording.

\subsection{Future Work}

Several future studies would clarify the function of the stake alignment and place it in a broader cultural context. As noted above, I identified very few wood stake/post sites recorded in the Lower Columbia in the Oregon and Washington archaeological sites databases, limiting comparative analysis. Future work could identify additional sites not currently distinguished during my initial key word search, for example. Ideally, enough sites with sufficient data would one day be identified to make useful statistical comparison possible.

That all stakes were created from western red cedar is noteworthy. The wood is both locally available and rot-resistant. However, other tree species were certainly common and locally available. Future research could investigate construction materials used in other local structures from both the 1800s, as well as the precontact era, and investigate similarities and differences in building materials, with the intention of inferring what pressures guide selection. 
Finally, future work at the Virginia Lake site should include additional survey and subsurface testing in the uplands adjacent the lake. These areas are privately owned and were not accessible as part of my project. However, given their higher elevation, and relatively flat topography, they pose a high probability for encountering evidence of past human occupation, which may elucidate the function or cultural affiliation of the stake alignment.

\subsection{Conclusions}

The goals of my thesis were to record the Virginia Lake feature and associated site, identify the age, cultural affiliation, and, function, and more broadly, relate the feature to human ecosystem engineering in the broader wetland landscape of the Lower Columbia. Based on the results of the archival research, fieldwork, and lab analysis, I can definitively say that the Virginia Lake feature dates to the mid-1800s. The feature's cultural affiliation and function remain more ambiguous. However, I was able to eliminate some hypotheses relating to function, narrowing the field of possibility.

The Virginia Lake feature is not a hunting platform/blind. The feature is not likely a post and line structure for straightening/storing cedar planks, and the feature is also not a boundary line or fence. Less clear is if the feature represents a pier structure, or a fish weir, as my results both support these hypotheses of function, and point toward inconsistencies in form.

That the fish weir hypothesis has not been eliminated is important, as facilities for catching fish that thrive in backwater environments have rarely been recorded, the Vancouver Lake site being an exception. Implications of this type of structure in a 
backwater wetland are significant, given ongoing debates about capture efficiency and intensification that rely heavily on concepts of mass capture. This hypothesis remains possible, but ambiguous.

In my study of the feature and its context, my research also contributes to the understanding of the history of Virginia Lake and its formation. Stratigraphic analysis and humin dating indicate that the lake was once a side channel of the Multnomah Channel, but has been separate for at least the last 1000 years. This information will aid in future interpretations of sites in the lake vicinity.

Despite the tentative nature of my conclusions, my thesis provides a methodological template for evaluating wetland landscape modifications, potentially increasing replicability and utility of comparison between these sites in the future. The question, hypotheses, task structure is helpful in evaluating unknown features, and this document outlines a standard procedure for recording this feature type. Furthermore, the larger theoretical framework explored in this document, creates a starting point for understanding and exploring these constructions as components in a broader system of human ecosystem engineering through the research program of historical ecology. 


\section{Bibliography}

Ames, Kenneth M.

1992 Archeological Context Statement: Portland Basin. Portland, OR. On file at the

Oregon State Historic Preservation Office, Salem.

1994 The Northwest Coast: Complex Hunter-Gatherers, Ecology, and Social

Evolution. Annual Review of Anthropology 23: 209-29.

2002 Going by Boat. In Beyond Foraging and Collecting, edited by Ben Fitzhugh and Junko Habu. Kluwer Academic/Plenum Publishers, New York, Boston, Dordrecht, London, Moscow.

Ames, Kenneth M., and Herbert D. G. Maschner

1999 Peoples of the Northwest Coast: their archaeology and prehistory. Thames and Hudson, New York.

Ames, Kenneth M., Cameron M. Smith, William L. Cornett, Elizabeth A. Sobel, and Stephen C. Hamilton

1999 Investigations at 45CL1 Cathlapotle (1991-1996), Ridgefield National Wildlife Refuge Clark County, Washington A Preliminary Report. On File at Portland State University, Portland.

Ames, Kenneth M, and Thomas J. Brown

2018 Radiocarbon Dating the Fur Trade: Bayesian Analyses of Fur-Trade Era Radiocarbon Dates from the Lower Columbia River. International Journal of Historical Archaeology.

Ames, Kenneth M, Katie Henry, Melissa Cole Darby, Stephen Coursalt Hamilton, Charles P Hodges, Kendal McDonald, Leslie M O Rourke, and Jonathan M White 2017 Geoarchaeology and Miscellaneous Reports: Cathlapotle and Meier Archaeological Sites, Lower Columbia River, Wapato Valley Archaeological Project Report \#13. Portland, OR. Report on file at Portland State University, Portland.

Ames, Kenneth M, Doria F Raetz, and Christine McAfee 1992 Household Archaeology of a Southern Northwest Coast Plank House. Journal of Field Archaeology 19(3): 275-286.

Ames, Kenneth M, and Emily E Shepard

2019 Building Wooden Houses: The Political Economy of Plankhouse Construction on the Southern Northwest Coast of North America. Journal of Anthropological Archaeology 53(2019): 202-221.

Anderson, M. Kat, Michael G. Barbour, and Valerie Whitworth

1997 A World of Balance and Plenty: Land, Plants, Animals, and Humans in a PreEuropean California. California History 76(2): 12-47. 
Arcas Associates

1986 Native Tree Use on Meares Island, B.C. Report prepared for Rosenberg,

Rosenberg, and Woodward, Baristers and Solicitors, Vancouver, BC.

Armstrong, Chelsey Geralda, Anna C. Shoemaker, Iain McKechnie, Anneli Ekblom, Péter Szabó, Paul J. Lane, Alex C. McAlvay, Oliver J. Boles, Sarah Walshaw, Nik Petek, Kevin S. Gibbons, Erendira Quintana Morales, Eugene N. Anderson, Aleksandra Ibragimow, Grzegorz Podruczny, Jana C. Vamosi, Tony Marks-Block, Joyce K.

LeCompte, Sakihitowin Awâsis, Carly Nabess, Paul Sinclair, and Carole L. Crumley 2017 Anthropological Contributions to Historical Ecology: 50 Questions, Infinite Prospects. PLoS ONE 12(2): 1-26.

Balee, W.

2006 The Research Program of Historical Ecology. Annual Review of Anthropology 35: 75-98.

Benito, Gerardo, and Jim E. O'Connor

2003 Number and size of last-glacial Missoula floods in the Columbia River valley between the Pasco Basin, Washington, and Portland, Oregon. GSA Bulletin 115(5): 624-638.

Bernick, Kathryn (editor).

1998 Hidden Dimensions: the cultural significance of wetland archaeology. UBC Press, Vancouver, BC.

BetaAnalytic

2019 Introduction to Radiocarbon Determination by the Accelerator Mass

Spectrometry Method. Electronic Document, Radiocarbon.com, accessed January 2019.

Binus, Joshua

2005 The Dalles Dam. The Oregon History Project. https:/ore gonhistoryproject.org/articles/historical-records/the-dallesdam/\#.XcZVrjNKjD4, accessed July 2019.

Bird, Douglas W., and James F. O'Connell

2006 Behavioral Ecology and Archaeology. Journal of Archaeological Research 14(2): 143-188.

Boyd, Robert T.

2013 Lower Chinookan Disease and Demography. In Chinookan Peoples of the Lower Columbia, edited by Robert T. Boyd, Kenneth M. Ames, and Tony A. Johnson. University of Washington Press, Seattle and London.

Boyd, Robert T., Kenneth M. Ames, and Tony A. Johnson (editors). 2013 Chinookan Peoples of the Lower Columbia. University of Washington Press, Seattle and London. 
Boyd, Robert T., and Yvonne P. Hajda

1987 Seasonal Population Movement along the Lower Columbia River: The Social and Ecological Context. American Ethnologist 14(2): 309-326.

Bronk Ramsey, Christopher

2001 Development of the Radiocarbon Calibration Program. Radiocarbon 43(2A): 355-363.

2009 Bayesian Analysis of Radiocarbon Dates. Radiocarbon 51(1).

Brown, Thomas J., Daniel M. Gilmour, Paul S. Solimano, and Kenneth M. Ames 2019 The Radiocarbon Record of the Western Stemmed Tradition on the Southern Columbia Plateau of Western North America. American Antiquity 84(3): 471494.

Butler, Virginia L.

2004 Where Have All the Native Fish Gone? Oregon Historical Society 105(3): 438 463.

Butler, Virginia L., and Sarah K. Campbell

2004 Resource intensification and resource depression in the Pacific Northwest of

North America: A zooarchaeological review. Journal of World Prehistory 18(4): 327-405.

Butler, Virginia L., and Michael A. Martin

2013 Aboriginal Fisheries of the Lower Columbia River. In Chinookan Peoples of the Lower Columbia, edited by Robert T. Boyd, Kenneth M. Ames, and Tony A. Johnson, 2600: University of Washington Press, Seattle and London.

Butler, Virginia L., and Michelle N. North

2018 Archaeological Research Design: Archaeological Testing Associated with Virginia Lake Feature, Wapato Greenway, Sauvie Island, Multnomah County, Oregon. Portland, OR. On file at Portland State University, Portland.

Byram, Robert Scott

2002 Brush Fences and Basket Traps: The Archaeology and Ethnohistory of Tidewater Weir Fishing on the Oregon Coast. PhD dissertation, Department of Anthropology, University of Oregon, Eugene.

Byram, Scott

1998 Fishing Weirs in Oregon Coast Estuaries. In Hidden Dimensions: The Cultural Significance of Wetland Archaeology, edited by Kathryn Bernick. UBC Press, Vancouver.

Caldwell, Megan E, Dana Lepofsky, Georgia Combes, Michelle Washington, John R Welch, and John R Harper

2012 A Bird' s Eye View of Northern Coast Salish Intertidal Resource Management Features, Southern British Columbia, Canada. Journal of Island \& Coastal Archaeology 7: 219-233. 
Campbell, Sarah K., and Virginia L. Butler

2010a Archaeological Evidence for Resilience of Pacific Northwest Salmon

Populations and the Socioecological System over the last 7, 500 years. Ecology and Society 15(1): 1-20.

2010b Fishes and Loaves? Explaining Sustainable, Long-Term Animal Harvesting on the Northwest Coast Using the "Plant Paradigm." In the Archaeology of Anthropogenic Environments, edited by Rebecca M. Dean, pp. 175-203. Board of Trustees, Southern Illinois University.

Canadian Conservation Institute

1997 Controlling Insect Pests with Low Temperature. CCI Notes (613): 1-4.

Cannif, KiKi

1981 Sauvie Island: a step back in time. Ki2 Enterprises, Portland, OR.

Cannon, Charles Matthew

2015 Landforms along the Lower Columbia River and the Influence of Humans.

Master's Thesis, Department of Geology, Portland State University, Portland.

Coles, J.M.

1984 The Archaeology of Wetlands. Edinburgh University Press, Edinburgh.

Comberti, C., T.F. Thornton, V. Wyllie De Echeverria, and T. Patterson

2015 Ecosystem services or services to ecosystems? Valuing cultivation and reciprocal relationships between humans and ecosystems. Global Environmental Change 34: 247-262.

Connaway, John M.

2007 Fishweirs: A World Perspective with Emphasis on the Fishweirs of Mississippi. Mississippi Department of Archives and History, Jackson, MS.

Costa-Pierce, Barry A.

1987 Aquaculture in Ancient Hawaii. BioScience 37(5): 320-331.

Croes, Dale R. (editor).

1976 The Excavation of Water-Saturated Archaeological Sites (Wet Sites) on the Northwest Coast of North America. University of Ottawa Press.

2001 North Coast Prehistory--Reflections from NWC Wet Site Research. In Perspectives on Northern Northwest Coast Prehistory, edited by Jerome S. Cybulski, pp. 145-171. Canadian Museum of Civilization, Hull, Quebec.

Croes, Dale R., John L. Fagan, and Maureen Newman Zehendner 2007 Testing the National Historic Landmark Wet Site 35MU4, The Sunken Village Archaeological Site, Multnomah County, Oregon. Olympia, WA and Portland, OR.

2009a Assessing the Results of the 2006 and 2007 Investigations at Sunken Village Wet Site. Journal of Wetland Archaeology 9(1): 185-201. 
2009b Artifact Analyses. Journal of Wetland Archaeology 9(1): 114-184.

2009c The 2006 and 2007 Field Seasons at Sunken Village. Journal of Wetland Archaeology 9(1).

Croes, Dale R., Rhonda Foster, Larry Ross, Melanie Diedrich, Nea Hubbard, Katherine M Kelly, Mandy Mccullough, Thomas Mccullough, Karen Myers, Cassandra Sharron, Barbara A Vargo, Rebecca J Wigen, and Lauren Valley

2005 Qwu? gwes - a Squaxin Island tribal heritage wet site , Puget Sound , USA. In Archaeology from the Wetlands: Recent Perspectives: Proceedings of the 11th WARP Conference. WARP Occasional Paper, Edinburgh.

Crumley, Carole L.

2007 Historical Ecology: Integrated Thinking at Multiple Temporal and Spatial Scales. In The World System and the Earth System: Global Socio-Environmental Change and Sustainability Since the Neolithic. Left Coast Press, Walnut Creek.

Darby, Melissa Cole

1996 Wapato for the people: an ecological approach to understanding the Native American use of Sagittaria latifolia on the lower Columbia River. Masters thesis, Department of Anthropology, Portland State University, Portland.

Deur, Douglas

2012 An Ethnohistorical Overview of Groups with Ties to Fort Vancouver National Historic Site. Pacific West Region: Social Science Series Number 2011-12. Department of the Interior, National Park Service. On file at Portland State University.

Deur, Douglas, Adam Dick, Kim Recalma-Clutesi, and Nancy J. Turner 2015 Kwakwaka 'wakw "Clam Gardens" Motive and Agency in Traditional

Northwest Coast Mariculture. Human Ecology (43): 201-212.

Deur, Douglas, and Nancy J. Turner 2005 Keeping It Living: Traditions of Plant Use and Cultivation on the Northwest Coast of North America. University of Washington Press, Seattle.

DirectAMS

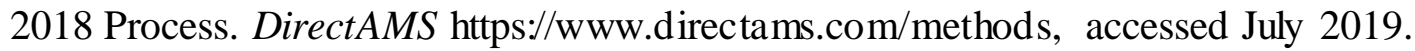

Eaton, W Clement

1935 Nathaniel Wyeth' s Oregon Expeditions. Pacific Historical Review 4(2): 101113.

Elder, J. Tait, Daniel M. Gilmour, Virginia L. Butler, Sarah K. Campbell, and Aubrey Steingraber

2014 On the Role of Coastal Landscape Evolution in Detecting Fish Weirs: A Pacific Northwest Coast Example from Washington State. Journal of Island \& Coastal Archaeology 9(1): 45-71. 
Ellis, David V.

2013 Cultural Geography. In Chinookan Peoples of the Lower Columbia, edited by

Robert T. Boyd, Kenneth M. Ames, and Tony A. Johnson, pp. 42-62. University of Washington Press, Seattle and London.

Erickson, C.L.

2000 An artificial landscape-scale fishery in the Bolivian Amazon. Nature 408(6809): 190-193.

Erlandson, Jon M., and Madonna L. Moss

1993 An Evaluation, Survey and Dating Program for Archaeological Sites on State Lands of the Central Oregon Coast. Report On file with the State Historic Preservation Office, Salem.

Fitzhugh, Ben, Virginia L. Butler, Kristine M. Bovy, and Michael A. Etnier

2019 Human Ecodynamics: A Perspective for the Study of Long-Term Change in Socioecological Systems. Journal of Archaeological Science: Reports 23(February): 1077-1094.

Fraser, James A.

2010 Caboclo Horticulture and "Caboclo" Horticulture and Amazonian Dark Earths along the Middle Madeira River, Brazil. Human Ecology 38(5): 651-662.

Gleeson, Paul F.

1980 Ozette Woodworking Technology. PhD Dissertation, Laboratory of Archaeology and History, Washington State University, Pullman.

General Land Office (GLO)

1854 Plat of Township No. 2 North, Range No. 1 West, Willamette Meridian.

Microfiche on file, U.S. Bureau of Land Management, Oregon State Office, Portland.

1862 Plat of Township No. 2 North, Range No. 1 West, Willamette Meridian.

Microfiche on file, U.S. Bureau of Land Management, Oregon State Office, Portland.

Grier, Colin

2014 Landscape Construction, Ownership and Social Change in the Southern Gulf Islands of British Columbia. Canadian Journal of Archaeology 38: 211-249.

Hajda, Yvonne P.

2013 Social and Political Organization. In Chinookan Peoples of the Lower Columbia, edited by Robert T. Boyd, Kenneth M. Ames, and Tony A. Johnson. University of Washington Press, Seattle and London.

Hajda, Yvonne P., and Elizabeth A. Sobel

2013 Lower Columbia Trade and Exchange Systems. In Chinookan Peoples of the Lower Columbia, edited by Robert T. Boyd, Kenneth M. Ames, and Tony A. Johnson. University of Washington Press, Seattle and London. 
Harper, J.R., J. Haggarty, and M.C. Morris

1995 Broughton Archipelago Clam Terrace Survey. Unpublished Report. Sidney, BC.

Harris, D.R., H.E. Gove, and P. Damon

1987 The Impact on Archaeology of Radiocarbon Dating by Accelerator Mass

Spectrometry [and Discussion]. Philosophical Transactions of the Royal Society

of London Series A, Mathematical and Physical Sciences 323(1569): 23-43.

Hastorf, Christine A

1999 Recent Research in Paleoethnobotany. Journal of Archaeological Research

7(1): 55-103.

Hewes, G.W.

1998 Fishing. In Handbook of North American Indians, vol.12: Plateau, edited by D.E. Walker, pp. 620-640.

Hibbs, Charles, and David V. Ellis

1988 An inventory of cultural Resources and an Evaluation of the Effects of the

Proposed North Coast Feeder Gas Pipeline, Located Between Deer Island and

Sauvie island, Lower Columbia River Valley, in Oregon. Portland, OR.

Hibbs, Charles, and Lester Ross

1972 Archaeological reconnaissance of the southern shore of Vancouver Lake, Clark

County, Washington. Report on file at the Washington Department of

Archaeology and Historic Preservation, Olympia.

Hoffmann, Tanja, Natasha Lyons, Debbie Miller, Alejandra Diaz, Amy Homan,

Stephanie Huddlestan, and Roma Leon

2016 Engineered feature used to enhance gardening at a 3800-year-old site on the

Pacific Northwest Coast. Science Advances (December): 1-8.

Hunn, Eugene S.

1990 Nch'i-Wana “The Big River”: Mid-Columbia Indians and Their Land.

University of Washington Press, Seattle and London.

Ives, B. and J. Hunt

1853 Field Notes of the Survey of the Township Two North of Range One West of the Willamette Meridian, in the Territory of Oregon. Microfiche copy on file, USDA Bureau of Land Management, Oregon State Office, Portland

Jay, David A, Keith Leffler, Heida L Diefenderfer, and Amy B Borde

2015 Tidal-Fluvial and Estuarine Processes in the Lower Columbia River: I . Along-

Channel Water Level Variations, Pacific Ocean to Bonneville Dam. Estuaries and Coasts 38: 415-433.

Kaye, Barry, David J. Cole-Hamilton, and Kathryn Morphet

2000 Supercritical Drying: A New Method for Conserving Waterlogged

Archaeological Materials. Studies in Conservation 45(4): 233-252. 
Kelly, Robert L.

1996 Foraging and Fishing. In Prehistoric Hunter-Gatherer Fishing Strategies, edited by Mark Plew. Boise State University Department of Anthropology.

2013 The Lifeways of Hunter-Gatherers: The Foraging Spectrum. Second ed. Cambridge University Press, New York.

Kirch, Patrick V.

1982 The Ecology of Marine Exploitation in Prehistoric Hawaii. Human Ecology 10(4): 455-476.

2017 (Editor) Tangatatau Rockshelter: The evolution of an Eastern Polynesian SocioEcosystem. UCLA Cotsen Institute of Archaeology Press, Los Angeles.

Kroeber, A.L., and S.A. Barrett

1960 Fishing Among the Indians of Northwestern California. Anthropological Records 21(1): 1-210.

Lang, William L.

2013 The Chinookan Encounter with Euro-Americans in the Lower Columbia River Valley. In Chinookan Peoples of the Lower Columbia, edited by Robert T. Boyd, Kenneth M. Ames, and Tony A. Johnson. University of Washington Press, Seattle and London.

Lepofsky, Dana, Chelsey Geralda Armstrong, Spencer Greening, Julia Jackley, Jennifer Carpenter, Brenda Guernsey, Darcy Mathews, and Nancy J. Turner

2017 Historical Ecology of Cultural Keystone Places of the Northwest Coast. American Anthropologist 119(3): 448-463.

Lepofsky, Dana, and Megan Caldwell

2013 Indigenous marine resource management on the Northwest Coast of North America. Ecological Processes 2(1): 12.

Lightfoot, Kent G., Rob Q. Cuthrell, Chuck J. Striplen, and Mark G. Hylkema 2013 Rethinking the Study of Landscape Management Practices Among HunterGatherers in North America. American Antiquity 78(2): 285-301.

Lindstrom, Susan

1996 Great Basin Fisherfolk: Optimal Diet Breadth Modeling the Truckee River Aboriginal Subsistence Fishery. In Prehistoric Hunter-Gatherer Fishing Strategies, edited by Mark Plew. Boise State University Department of Anthropology.

Losey, Robert

2010 Animism as a Means of Exploring Archaeological Fishing Structures on Willapa Bay, Washington, USA. Cambridge Archaeological Journal 20(January 2010): 17-32.

Lyman, R. Lee

1994 Mammalian Zooarchaeology of the Meier Site (35C05). Columbia, MO. 
2003 Mammalian Zooarchaeology of Cathlapotle (45CL1): Descriptive Paleontology and Taphonomic Analyses. Columbia, MO.

McKey, Doyle B., Mélisse Durécu, Marc Pouilly, Philippe Béarez, Alex Ovando, Mashuta Kalebe, and Carl F. Huchzermeyer

2016 Present-day African Analogue of a Pre-European Amazonian Floodplain Fishery Shows Convergence in Cultural Niche Construction. Proceedings of the National Academy of Sciences 113(52): 14938-14943.

McKey, Doyle, Stéphen Rostain, José Iriarte, Bruno Glaser, Jago Jonathan, Irene Holst, and Delphine Renard

2010 Pre-Columbian Agricultural Landscapes, Ecosystem Engineers, and Self-

Organized Patchiness in Amazonia. PNAS 107(17): 7823-7828.

Miller, Tyler G. Jr., and Scott E. Spoolman

2009 Living in the Environment. Brooks/Cole, Belmont.

Ming, Huang Pan, Yuncong Li, and Malcom E. Sumner (editors).

2011 Handbook of Soil Sciences Properties and Processes. CRC Press, Boca Raton.

Mohlenhoff, Kathryn A., and Brian F. Codding

2017 When Does It Pay to Invest in A Patch? The Evolution of Intentional Niche

Construction. Evolutionary Anthropology 26(5): 218-227.

Moss, Madonna L.

2013 Fishing traps and weirs on the Northwest Coast of North America: New approaches and new insights. In Oxford Handbook of Wetland Archaeology, edited by F. Menotti and A. O'Sullivan, pp. 323-338. Oxford University Press, Oxford.

Moss, Madonna L., Jon M. Erlandson, and Robert Stuckenrath

1990 Wood Stake Weirs and Salmon Fishing on the Northwest Coast: Evidence from

Southeast Alaska. Canadian Journal of Archaeology 14(1990): 143-158.

Moulton, Gary (editor).

1991 The Journals of the Lewis and Clark Expedition. University of Nebraska Press, Lincoln.

Muller, R.A.

1977 Radioisotope Dating with a Cyclotron. Science 196(4289): 489-494.

Naik, Pradeep K., and David A. Jay

2005 Estimation of Columbia River Virgin Flow: 1879 to 1928. Hydrological

Processes 19(October).

Neuzil, Anna A

2018 Supplemental Cultural Resources Inventory for the Columbia River Stock Ranch Project, Columbia County, Oregon. Portland, OR. Report on file at the Oregon State Historic Preservation Office, Salem. 
Newman, Maureen

1991 Description and Management Plan for 35MU4, The Sunken Village

Archaeological Site at Sauvie Island, Multnomah County, Oregon. Masters

Thesis, Department of Anthropology, Portland State University, Portland.

O’Connor, Jim

2012 Thumbnail Geologic History of Sauvie Island. U.S. Geological Survey.

O’Connor, Jim, Andrei Sarna-Wojcicki, Karl C. Wozniak, Danial J. Polette, and Robert J. Fleck

2001 Origin, Extent, and Thickness of Quaternary Geologic Units in the Willamette Valley, Oregon. U.S. Geological Survey, Professional Paper 1620.

Oregon Parks and Recreation Department

2013 Wapato State Green Way Comprehensive Plan. Report on file at the OPRD offices in Salem.

Oregon State Archive

1973 Warranty Deed [WD]. ODOT\# 47952, 7/19/1973. On file at Oregon State Archives, Salem, OR.

1973 Warranty Deed. ODOT\#47710, 3/28/1973. On file at Oregon State Archives, Salem, OR.

1973 Warranty Deed. ODOT\# 47709, 3/28/1973. On file at Oregon State Archives, Salem, OR.

1973 Warranty Deed. ODOT\# 47703, 2/2/1973. On file at Oregon State Archives, Salem, OR.

1973 Warranty Deed. ODOT\# 47933, 7/31/1973. On file at Oregon State Archives, Salem, OR.

Pettigrew, Richard M.

1973 Oregon Archaeological Survey 35MU4. Report on file at the Oregon State Historic Preservation Office, Salem.

1977 A Prehistoric Culture Sequence in The Portland Basin of The Lower Columbia Valley. PhD Dissertation, Department of Anthropology, University of Oregon, Eugene.

1981 A Prehistoric Culture Sequence in the Portland Basin of the Lower Columbia Valley. University of Oregon Anthropological Papers 22.

Pettigrew, Richard M., Catherine Blosser, Virginia L. Butler, Jr. Foit, F. Franklin, Charles Hodges, R. Lee Lyman, Craig E. Skinner, and Anne Trieu 2005 Archaeological Excavations at the St. Johns Site (35MU44/46), Portland,

Oregon. Report on file at the Oregon State Historic Preservation Office, Salem.

Pettigrew, Richard M, and Clayton G Lebow

1987 Archaeological Investigations at the Sunken Village Site (35MU4), Multnomah

County, Oregon. Report on file at the Oregon State Historic Preservation Office, Salem. 
Proulx, Gilbert

2012 Fur Trapping. The Canadian Encyclopedia, https $/ / \mathrm{www}$.thecanadianencyclopedia.ca/en/article/fur-trapping, Accessed June $27,2019$.

Raup, H.F.

1947 The Fence in the Cultural Landscape. Western Folklore 6(1): 1-7 and 9-12.

Ray, V.F.

1938 Lower Chinook Ethnographic Notes. University of Washington Publications in Anthropology 7(2).

Robbins, William G

1997 Landscapes of Promise: The Oregon Story, 1800-1940. University of Washington Press, Seattle.

Rostlund, Erhard

1952 Freshwater Fish and Fishing In Native North America. University of California Press, Berkeley and Los Angeles.

Saleeby, Becky Margaret

1983 Prehistoric Settlement Patterns in the Portland Basin of the Lower Columbia

River: Ethnohistoric, Archaeological, and Biogeographic Perspectives. $\mathrm{PhD}$

Dissertation, Department of Anthropology, University of Oregon, Eugene.

Sampson, C Garth, C Melvin Aikens, James A Bennyhoff, Ruth L Greenspan, Richard E Hughes, and Joanne M Mack

1985 Nightfire Island: Later Holocene Lakemarsh Adaptation on the Western Edge.

University of Oregon Anthropological Papers 33.

Schalk, Randall, and Greg Burtchard

2001 The Newskah Creek Fish Trap Complex Grays Harbor, Washington. Report on file at the Washington Department of Archaeology and Historic Preservation, Olympia.

Smith, Bruce D.

2007 The Ultimate Ecosystem Engineers. Science 315(March): 1797-1799.

Sobel, Elizabeth A., Kenneth M. Ames, and Robert Losey

2013 Environment and Archaeology of the Lower Columbia. In Chinookan Peoples of the Lower Columbia, edited by Tony A. Johnson Boyd, Robert T, Kenneth M. Ames. University of Washington Press, Seattle and London.

Spencer, Omar C.

1950 The Story of Sauvies Island. Binfords and Mort, Portland, OR.

Stewart, Hilary

1984 Cedar. Douglas and McIntyre, Vancouver and Toronto. 


\section{Strong, Emory}

1959 Stone Age on the Columbia River. Binfords and Mort, Portland.

Suttles, W.P. (editor).

1990 Handbook of the North American Indians, Northwest Coast, Vol. 7.

Smithsonian Institution, Washington, DC.

Taylor, Herbert C., and Lester L. Hoaglin

1962 The " Intermittent Fever " Epidemic of the 1830's on the Lower Columbia

River. Ethnohistory 9(2): 160-178.

Thornton, Thomas, Douglas Deur, and Herman Kitka Sr

2015 Cultivation of Salmon and other Marine Resources on the Northwest Coast of North America. Human Ecology: 189-199.

Trieu Gahr, D. Ann

2013 Ethnobiology: Nonfishing Subsistence and Production. In Chinookan Peoples of the Lower Columbia, edited by Robert T. Boyd, Kenneth M. Ames, and Tony A. Johnson, pp. 63-79. University of Washington Press, Seattle and London.

Turner, Nancy J., Douglas Deur, and Dana Lepofsky

2013 Plant Management Systems of British Columbia's First Peoples. BC Studies:

The British Columbian Quarterly 179: 107-133.

Tushingham, Shannon, and Colin Christiansen

2015 Native American Fisheries of the Northwestern California and Southwestern Oregon Coast: A Synthesis of Fish-Bone Data and Implications for Late Holocene Storage and Socio-Economic Organization. Journal of California and Great Basin Anthropology 35(January): 189-215.

Tveskov, Mark A., and Jon M. Erlandson

2003 The Haynes Inlet weirs: Estuarine fishing and archaeological site visibility on the southern Cascadia coast. Journal of Archaeological Science 30(8): 10231035 .

United States Geological Survey (USGS)

1915 Hillsboro, OR. Scale 1:62500 topographic map.

1940 Hillsboro, OR. Scale 1:62500 topographic map.

1954 Sauvie Island, OR. 7.5 min 1:2400 scale topographic map.

United States Army Corps of Engineers (USACE)

1929 Aerial Image, Sauvie Island Oregon. On file at the USACE, Eugene.

Vale, Thomas (editor).

2002 Fire, Native Peoples, and the Natural Landscape. Island Press.

Walsh, Megan Kathleen

2008 Natural and Anthropogenic Influences on The Holocene Fire and Vegetation

History of the Willamette Valley, Northwest Oregon, and Southwest Washington. $\mathrm{PhD}$ Dissertation, Department of Geography, University of Oregon, Eugene. 
Werz, Bruni E. J. S., and Ute A. Seemann

1993 Organic Materials from Wet Archaeological Sites: The Conservation of Waterlogged Wood. The South African Archaeological Bulletin 48(157): 37-41.

Wessen, Gary

1983 Archeological Investigations at Vancouver Lake, Washington. Report on file at the Washington Department of Archaeology and Historic Preservation Olympia.

Willingham, William $\mathrm{F}$

2018 U.S. Army Corps of Engineers. The Oregon Encyclopedia, https:/oregonencyclopedia.org/articles/u_s__army_corps_of_engineers/\#.XcZizjN KjD4, accessed July, 2019. 


\section{Appendix A: Oregon SHPO Archaeological Permit}

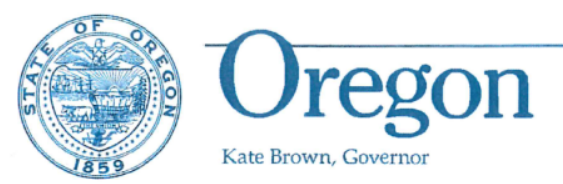

\section{STATE OF OREGON \\ ARCHAEOLOGICAL EXCAVATION PERMIT NO. AP-2538}

Parks and Recreation Department State Historic Preservation Office 725 Summer St NE Ste C Salem, OR 97301-1266 Phone (503) $986-0690$ Fax (503) 986-0793 www.oregonheritage.org

The State of Oregon, acting by and through its Parks and Recreation Department, hereinafter called STATE, under authority of ORS 390.235 , hereby grants to Virginia Butler, hereinafter called PERMITTEE, a permit for purposes of excavation and removal of archaeological, historical, prehistoric, or anthropological materials. This permit is granted subject to the following terms and conditions.

1. $\underline{\text { Term }}$ PERMITTEE may conduct survey, excavation, and collection work from $7 / 23 / 2018$ to $7 / 24 / 2019$ provided that reasonable supervision, as provided hereinafter, is exercised.

2. Location This permit shall apply to lands owned by the State of Oregon, a city, county, district, or municipal corporation in Oregon, or private property, more particularly described as follows:

Archaeological Testing of the Virginia Lake Feature

2n 1 w 7, 2, 17, 18

Multnomah County

3. Supervision The design and work in connection with the survey or excavation, including exploratory excavation and collection, shall be personally supervised by Virginia Butler, Shelby Anderson, Anthony Hofkamp.

4. Compliance PERMITTEE shall comply with all applicable federal, state and local laws, rules, regulations and ordinances.

\section{Exploration shall consist of:}

Subsurface Porbe Survey

Subsurface shovel probe survey will be conducted near the feature itself. The purpose of the subsurface shovel probes is to determine the vertical and horizontal extent of the site, and the presence/absence of additional buried cultural materials or aspects of the feature. Although it is unusual to find artifacts directly near an in situ weir (Byram 2002), it is necessary to conduct subsurface shovel probe survey to confirm site extent and determine if buried components exist (NPS 2018). Shovel probes will be round and spaced approximately 15 meters apart, radiating out from the feature. If no additional cultural resources are encountered, then shovel probes will be terminated 30 meters distance from the surface exposed portion of the feature. It is estimated that given the spacing and size of the feature, up to 15 probes will be excavated, dependent on field conditions and the results of the pedestrian survey. Probes will be approximately $50 \mathrm{~cm}$ in diameter and no smaller than 30 centimeters, and will be excavated to 1 meter (a minimum of 50 centimeters), or until the water table or another impassible obstruction is encountered. If it is deemed necessary to view stratigraphy below 1 meter, an auger probe will be used to extend the depth of the hole to characterize the deposits. All excavated material will be screened through $1 / 8$ " mesh hardware cloth. If cultural resources are encountered in shovel probes, a sediment sample (up to 1 liter) will be removed for flotation or nested screening. All probes will be backfilled upon completion.

Shovel probe locations will be mapped using a handheld Global Positioning System (GPS) unit accurate to 1 meter. Soil descriptions and measurements will be recorded for each probe. Digital photographs will be taken of all subsurface probes. All cultural materials, both precontact and historic, encountered in shovel probes will be photographed and collected. Modern debris and otherwise unmodified fire modified rock (FMR) will be photographed and counted in the field but not collected. 
Feature Specific Testing and Sample Collection

Feature specific testing and sample collection will be informed by the results of the shovel probe survey. Identification of additional features, or unique areas or divisions within the existing feature, will inform test placement. To determine the age, nature, and function of the feature, it is necessary to remove a sample of the wooden stakes for analysis. Because weirs are known to have been repaired, maintained, and rebuilt over time ( Byram 2002; Losey 2009; Schalk and Burtchard 2001), stakes from different sections of the feature, and in differential states of preservation will be chosen, with the goal of determining the duration of the feature's use. Two stakes will be removed for a combination of radiocarbon dating, macrobotanical identification, and analysis of modification- specifically tool marks. Removal of stakes for this analysis will be conducted through excavation of 50x50 cm tests, as part of testing adjacent to the selected stake. These tests will be square and excavated using 10-centimeter arbitrary levels. 50x50 tests may be extended to $50 \mathrm{~cm} \times 1 \mathrm{~m}$ or $1 \times 1 \mathrm{~m}$, as is necessary to sufficiently view and interpret the feature and deposits. No more than the equivalent of two $1 \times 1 \mathrm{~m}$ units of material will be excavated during feature specific testing. Tests will be excavated to a depth of 20 centimeters after the base of the stake or below sterile deposits (sterile is defined as the absence of cultural material). Should excavation not be able to reach this depth due to water table intrusion, the tests will have an auger placed in the bottom and excavated to that level using the auger. All removed sediments will be screened through $1 / 8$ " mesh hardware cloth. All test locations will be mapped using a handheld GPS unit.

A column sample will be removed from one wall of each test for flotation and systematic study of soil sediment characteristics. If faunal or botanical cultural material are encountered a bulk sample for flotation will be collected (up to 1 liter). One wall of each test will be profiled. All tests will be photographed. All archaeological cultural materials, both precontact and historic, encountered during sub surface test excavations will be collected. Modern debris and otherwise unmodified FMR, will be counted and photographed in the field, then discarded. Tests will be backfilled upon completion of documentation. All cultural materials encountered during excavations will be bagged and labeled with test/probe number and level depth in the field and transported to Dr. Butler's Lab at Portland State University for processing

As mentioned above, weirs are known to have been repaired, maintained, and used over long time periods, sometimes hundreds of years. To obtain a more reliable estimate of age for the feature, and detect phases of remodel, if any, it would be ideal to obtain more than two radiocarbon dates. Given the conservation ethic and the small sample size needed for Accelerator Mass Spectrometry (AMS) dates, we would like to obtain additional in situ samples from the feature stakes. Up to three additional wooden stakes may be left in place and sampled "in situ" for radiocarbon dating and/or macrobotanical identification, as it is not necessary to remove the bottom portion of the stake to obtain a sample sufficient for an AMS radiocarbon date or macrobotanical identification. Additional samples will be photographed and documented. To estimate the chronology of the feature's use, these dates will be used in concert with macrobotanical, ethnographic, and tool mark analysis data to determine age and narrow the possibilities of the features function.

6. Indemnification PERMITTEE agrees to defend and hold STATE, its officers, agents, and employees harmless, and shall require its contractors to do the same, from any and all claims, damages, or expenses of any kind suffered or alleged to be suffered on the lands described in paragraph 2 or arising out of or in connection with the activities of PERMITTEE or its contractors pursuant to this Permit.

7. Insurance PERMITTEE shall obtain at PERMITTEE's expense, and keep in effect during the term of the Permit, comprehensive or commercial general liability insurance covering personal injury and property damage. This insurance shall include contractual liability coverage for the indemnification provided under this Permit. Coverage limits shall not be less than the limits of liability set forth in the provisions of ORS $30.270(1)$ as now in effect or as hereinafter amended. Such provisions now require that the coverage limits not less than $\$ 500,000$ combined single limit per occurrence. The insurance shall be in a form and with compliance acceptable to STATE. Such insurance may be evidenced by certificates or copies of policies. Such evidence shall be provided to STATE prior to the commencement of any operations or activities under this Permit. 
8. Records PERMITTEE shall submit a final excavation report by $7 / 23 / 2020$ to the State Historic Preservation Office and the Oregon State Museum of Anthropology. If PERMITTEE is conducting an excavation associated with a prehistoric or historic American Indian archaeological site, then PERMITTEE shall also submit copies of the Final Report to the Commission on Indian Services and the following tribe(s):

\section{Conf Tribes of the Warm Springs Resv Confederated Tribes of Grand Ronde Confederated Tribes of Siletz Indians}

\section{Custody}

All archaeological, historical, prehistoric, or anthropological materials recovered under this permit shall remain under the stewardship of the State of Oregon and shall be curated by UOMNCH. Any change in custody must be approved by the Oregon State Museum of Anthropology in accordance with ORS 390.235. Prior to submitting the materials to the permanent curation facility, the appropriate tribe(s) must be given 30 days to view all archaeological materials to ensure that funerary objects, sacred objects, and objects of cultural patrimony are returned to tribal ownership per state law (ORS 97.740).

\section{Notification}

a. If PERMITTEE is conducting an excavation associated with a prehistoric or historic American Indian archaeological site, PERMITTEE shall notify in writing the most appropriate Indian tribe. The notification shall include:

i. The location and schedule of the forthcoming excavation;

ii. A description of the nature of the of the investigation; and

b. Upon discovery of an archaeological object which is demonstrably revered by any ethnic group, religious group, or Indian tribe as holy, which object was or is used in connection with a religious or spiritual service or worship of a deity or spirit power, i.e., a "sacred object", PERMITTEE shall notify in writing:

i. The State Historic Preservation Office; and

ii. The appropriate ethnic group, religious group, or Indian tribe with which the sacred object is associated.

11. Consultation If PERMITTEE is conducting an excavation associated with a prehistoric or historic American Indian archaeological site, PERMITTEE shall consult with a representative of the appropriate tribe to establish a procedure for handling sacred objects recovered during the excavation.

\section{Conditions:}

Nancy Nelson, Oregon Parks and Recreation Dept (Landowner)

Please provide the OPRD archaeologist, Nancy Nelson (503-339-6713) and the park manager, Guy Rodrigue (503-805-9435), 24 hour notice before beginning fieldwork. Also, the park manager has requested that the archaeologists have clearly identifiable clothing or signage so the general public understands that the work is of official capacity.

\section{Confederated Tribes of Grand Ronde}

1. A fieldwork schedule is sent to our office at least a week prior to field work start date. 2 . If requested by our office, we are provided access to the site and opportunity to observe field work. 3 . If suspected funerary or sacred items are identified, work be stopped an our office be notified immediately. 4 . We are given a copy of the draft archaeological report with sufficient time to comment on the findings. 5. Prior to submission of the draft report, photos with scale of all artifacts encountered be provided to the Tribes in an effort to identify to ensure that funerary objects, sacred objects, and objects of cultural patrimony are returned to Tribal ownership as per State Law

13. Revocation Failure to comply with all terms of this Permit, in addition to any agreed upon conditions, may lead to its immediate revocation. 


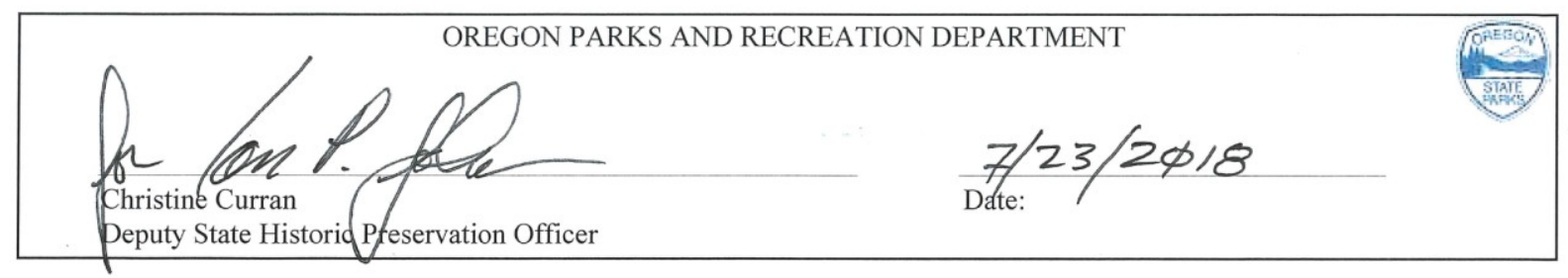




\section{Appendix B: OPRD Scientific Research Permit}

Permit \# 30-18

Permit Expires: 9/30/2018

\section{Oregon Parks and Recreation Department Scientific Research Permit Application}

Instructions: Applications must be typewritten with original signatures. The precise location of the proposed work must be shown on an USGS topographic map and aerial photo. Application should be sent to the Department's Salem office.

Please allow for a minimum of 30 days to process the permit application.

Applicant's Name:

Title:

Affiliation:

Address:

City/State/Zip:

Telephone Number:

Fax Number:

E-mail address:
Virginia L. Butler

\begin{tabular}{l}
\hline Anthropology Department Chair, Professor \\
\hline Portland State University \\
\hline P.O. Box 751 \\
\hline Portland, OR, 97207 \\
\hline (503) 725-3303 \\
\hline Virginia@pdx.edu \\
\hline
\end{tabular}

Names of others involved in project/study, including names and phone numbers of all collectors:

\begin{tabular}{|l|l|}
\hline Michelle North & \\
\hline Patrick Reed & \\
\hline Anthony Hofkamp & \\
\hline Emily Taber & \\
\hline
\end{tabular}

*Field crew subject to availability

$\bigotimes$ Resume or curriculum vitae for principal investigator and all field staff attached (required)

Updated $02 / 2018$

Page 2 of 7 


\section{PROJECT DESCRIPTION:}

Include: Purpose, method of investigation, method of collection, species to be investigated and/or collected, steps to be taken to minimize impact, location and duration of project. Please include a project proposal if available. However, please do not simply say, "see attached." Include a brief project summary in the space provided below.

This project seeks to officially record the nature, character, and extent of an archaeological site in Virginia Lake, on Sauvie Island, Multnomah County, Oregon that consists of an alignment of wooden stakes, and to use this information to explore research questions pertaining to Indigenous cultivation and human ecosystem engineering in the Lower Columbia. Methodology will include noninvasive pedestrian foot survey of Virginia Lake, subsurface shovel testing $(8-15 \sim 30 \mathrm{~cm}$ to $50 \mathrm{~cm}$ wide $\sim 50 \mathrm{~cm}$ deep tests) within $30 \mathrm{~m}$ of the wood stake feature, and the removal of 2 wooden stakes from the feature for analysis using controlled hand excavation of two $\sim 50 \times 50 \mathrm{~cm}$ test units (to a maximum of $1 \times 1 \mathrm{~m}$ ). All subsurface tests will be backfilled upon completion. Two additional 1-liter soil samples may be collected for additional analysis if faunal, botanical, or other culturally associated material is encountered in the test units. All excavations will be backfilled after work is complete. All test areas and features associated with the site will be mapped using a handheld GPS unit. This is the minimum number of samples and tests deemed necessary for obtaining the information needed to answer the proposed research questions and accurately record the site.

Because the archaeological feature is only accessible when Virginia Lake is dry in the late summer and early fall, work will need to take place during this window. The fieldwork will take approximately 4 days, and is planned to occur between August 31 and September 12, 2018, when aerial photographs indicate Virginia Lake is most likely to be dry.

For more detailed descriptions of field methodology please see the attached SHPO archaeological excavation permit research design.

\section{SAMPLE/SPECIMEN COLLECTION:}

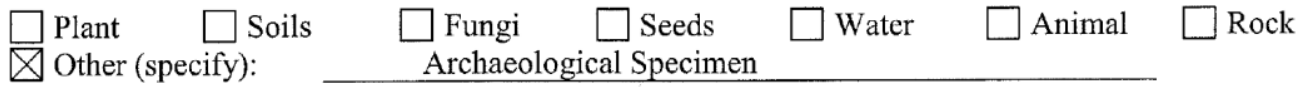


Permit \# 30-18

Permit Expires: 9/30/2018

If Plant/Animal - Identify the species to be researched or collected:

Name of Species N/A

Is/are the species a:

Federal endangered or threatened species?

Yes $\square$ No

Federal candidate species?

State endangered or threatened species?

State sensitive or candidate species?

Yes $\square$ No

Yes $\square$ No

Yes $\square$ No

Voucher specimens will be deposited at:

Will the project involve ground disturbance: Yes $\square$ No

\section{Additional Permits:}

Are additional federal or state permits required? Yes $\bigotimes$ No $\square$

If so, please list and provide a copy of each permit:

Oregon State Historic Preservation Office

Archaeological Permit No. 2538 (in review- see

attached research design)

\section{Area for Proposed Study:}

Please note that OPRD's jurisdiction includes all state parks AND that portion of Oregon's coastal zone from extreme low tide to the statutory or actual vegetation line, whichever is most landward and $1 / 4$ mile on each side of the river of all State Scenic Waterways. 
The proposed project area is approximately 60 acres located in Virginia Lake, in the Oregon Parks and Recreation Department (OPRD) Wapato Greenway recreation area on Sauvie Island in Multnomah County, Oregon at the confluence of the Willamette and Columbia Rivers (see attached map). It lies predominantly in Section 17, Township 2 North, Range 1 West, with portions of the project area intersecting the Northeast corner of Section 18, the Southeast corner of section 7, and the Southwest corner of Section 8.

The project area encompasses $\sim 60$ acres, however ground disturbance will only be conducted within an approximately .65-acre area within and adjacent to the archaeological feature (see attached map). The remaining project area will only be examined visually through non-invasive pedestrian survey.

Dates of Proposed Study: Project Begin Date/Project End Date

\begin{tabular}{|l|l|l|}
\hline $\begin{array}{l}\text { August } 31,2018- \\
\text { September } 12,2018\end{array}$ & \\
\hline
\end{tabular}

The dates of field work are dependent on the water level of Virginia Lake. Work can only take place when the lake is dry. Therefore- these dates are approximate. Field work will take approximately 4 days to complete but may occur anywhere within the listed dates due to water level (with notice).

\section{Scientific Research Permit Standard Permit Conditions and Restrictions}

By acceptance of this permit, Permittee agrees to abide by the following conditions:

1. All activities shall comply with applicable federal, state, and local laws, regulations, and ordinances. Any necessary federal, state, or local permits shall be obtained prior to the beginning of the activity. Copies of those permits must be provided to the Park Manager before work begins.

2. The Permittee assumes full responsibility and liability for any damages or injury to any member of the public arising out of the activity, including personal injury and property damage, and for any damage to park property.

3. The Permittee shall indemnify and hold harmless the State of Oregon, its Parks and Recreation Commission and members thereof, the State Parks and Recreation Department, and its officer, agents, and employees against any and all damages, claims, or causes of action arising from or in connection with the activity.

4. The study shall be completed only in those areas identified in the permit application and as identified on a 1:24,000 scale USGS map with a circle drawn around the proposed study area.

5. The Permittee shall carry a copy of this permit at all times while on OPRD managed or owned property, and must be able to show the permit to OPRD staff upon request. 
6. The collections allowed under this permit shall be used for scientific or educational purposes only, shall be dedicated to the public benefit, and shall not be used for commercial purposes.

7. Except for the resources indicated in the permit, the taking or disturbing of resources is specifically prohibited.

8. Any permitted holes dug must be refilled. All holes must be dug with a shovel or a hand auger.

9. The collection of plants shall not occur within 200 feet of any road, parking lot, trail, campground, picnic area, or restroom, unless the collecting site is completely screened from view, in which case 100 feet will be the minimum distance.

10. No more than $1 \%$ of the population will be collected (i.e., one out of every hundred individuals). Permittee will use scientific judgment and will collect specimens only from populations that can tolerate collection without jeopardizing the viability of that population.

11. The Permittee shall submit a summary of the information gathered to the Park Manager where the investigations took place, and to the OPRD Stewardship Section in Salem, Oregon. The Department further requires that the Permittee shall provide to the Department any materials published because of this permit.

12. Contact the Park Manager(s) at least 24 hours prior to each occurrence of the permitted activity.

13. OPRD reserves the right to cancel this permit for any reason.

14. For activities on the ocean shore, a special drive-on-beach permit is needed for any areas closed to motor vehicles.

15. If any cultural material is discovered during a project, all work and operations must stop immediately and an OPRD archeologist must be contacted to assess the discovery. Contact Coastal Region Archaeologist Steve Willis at (541) 272-9353; Valleys Region Archaeologist Nancy Nelson at (503) 986-0578, and Mountains Region Steve Jenevein at (541) 971-301-3956.

16. Drone Usage Policy: 1) permit holder meet current FAA standards and provide us either a remote pilot certificate for Pilot in Command (PIC) or an FAA issued Certificate of Authorization (COA); 2) the aircraft must also be registered with the FAA and if the operator is a public entity in Oregon, with the Oregon Department of Aviation; 3) Additionally, you would need to contact Park Manager(s) at each specific park prior to using drones in their management areas.

\section{OPRD Special Conditions Imposed: Do not write in box below, for reviewer use only.}

Special conditions apply: $Х$ As follows $\square$ See attached

1. Provide OPRD Archaeologist Nancy Nelson, 503-339-6713, and Park Manager Guy Rodrigue, 503-805-9435, 24 hour notice before beginning field work.

2. Anyone onsite have equipment, clothing, and shoes free from dirt, plants, or seeds from other sites to avoid spreading invasive flora and fauna.

3. The information from this research would help OPRD and others have a better understanding of the site's role and importance and may be important for future aquatic restoration. Please share your findings with Natural Resource Specialist Andrea Berkley, 503-360-8656, and please refer to Standard Condition \#11 above. 
Permit \#

Permit Expires:

I, the undersigned, have read and hereby agree to the conditions and restrictions listed above. I further understand that the department may impose special conditions. I hereby agree to abide by any special conditions if this permit is granted.

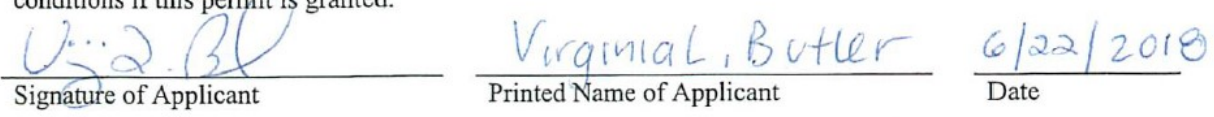

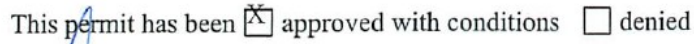

\begin{tabular}{l|l} 
Wotthen for & $\begin{array}{r}\text { Scott Nebeker for } 8-28-18 \\
\text { Trevor Taylor, OPRD Stewardship Manager }\end{array}$ \\
Printed Name Stewardship Manager & Date
\end{tabular}

Applicant must carry this permit at all times while on state park owned or managed properties

Email application to:

sara.griffith@oregon.gov

OR

Mail application to:

Oregon Parks and Recreation Department

Attention: Stewardship Section

725 Summer Street, NE Suite C

Salem, Oregon 97301

For further information, contact:

Sara Griffith, Stewardship Assistant, (503) 986-0737 


\section{Appendix C: DirectAMS Reports}

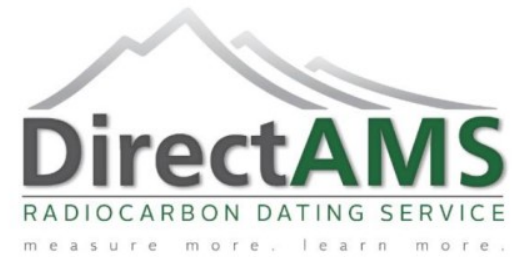

Report: 2149-032092-032094

Customer: 2149

Michelle North

Portland State University

Department of Anthropology

PO Box 751 - ANTH

Portland, OR 97207

USA

Samples submitted for radiocarbon dating have been processed and measured by AMS. The following results were obtained:

\begin{tabular}{|c|c|c|c|c|c|c|}
\hline \multirow{2}{*}{ DirectAMS code } & \multirow{2}{*}{ Submitter ID } & \multirow{2}{*}{ Sample type } & \multicolumn{2}{|c|}{ Fraction of modern } & \multicolumn{2}{|c|}{ Radiocarbon age } \\
\cline { 4 - 7 } & & & pMC & 1 $\sigma$ error & BP & 1 $\sigma$ error \\
\hline D-AMS 032092 & 1 & wood & 99.49 & 0.30 & Modern & \\
\hline D-AMS 032093 & 2 & wood & 99.11 & 0.33 & 72 & 27 \\
\hline D-AMS 032094 & 3 & wood & 98.43 & 0.32 & 127 & 26 \\
\hline
\end{tabular}

Results are presented in units of percent modern carbon $(\mathrm{pMC})$ and the uncalibrated radiocarbon age before present (BP). All results have been corrected for isotopic fractionation with an unreported $\delta^{13} \mathrm{C}$ value measured on the prepared carbon by the accelerator. The pMC reported requires no further correction for fractionation.

11822 North Creek Parkway N, Suite \#107, Bothell, WA 98011

Tel (425) 481-8122 - www.DirectAMS.com

Page 1 of 1 


\section{DirectAMS}

Report: 2149-033449-033451

30 May 2019

Customer: 2149

Michelle North

4131 SW View Point Terrace \#4

Portland, OR 97239

USA

Samples submitted for radiocarbon dating have been processed and measured by AMS. The following results were obtained:

\begin{tabular}{|c|c|c|c|c|c|c|}
\hline \multirow{2}{*}{ DirectAMS code } & \multirow{2}{*}{ Submitter ID } & \multirow{2}{*}{ Sample Type } & \multicolumn{2}{|c|}{ Fraction of modern } & \multicolumn{2}{|c|}{ Radiocarbon age } \\
\cline { 4 - 7 } & & & pMC & 1 $\sigma$ error & BP & $1 \sigma$ error \\
\hline D-AMS 033449 & Sample 4 & wood & 98.58 & 0.48 & 115 & 39 \\
\hline D-AMS 033450 & Sample 5 & wood & 98.83 & 0.43 & 95 & 35 \\
\hline D-AMS 033451 & Sample 6 & wood & 99.55 & 0.31 & Modern & \\
\hline
\end{tabular}

Results are presented in units of percent modern carbon (pMC) and the uncalibrated radiocarbon age before present (BP). All results have been corrected for isotopic fractionation with an unreported $\delta^{13} \mathrm{C}$ value measured on the prepared carbon by the accelerator. The pMC reported requires no further correction for fractionation.

11822 North Creek Parkway N, Suite \#107, Bothell, WA 98011

Tel (425) 481-8122 - www.DirectAMS.com

Page 1 of 1 


\section{DirectAMS}

Report: 2149-033689

21 June 2019

Customer: 2149

Michelle North

4131 SW View Point Terrace \#4

Portland, OR 97239

USA

Samples submitted for radiocarbon dating have been processed and measured by AMS. The following results were obtained:

\begin{tabular}{|l|c|c|c|c|c|c|}
\hline \multirow{2}{*}{ DirectAMS code } & \multirow{2}{*}{ Submitter ID } & \multirow{2}{*}{ Sample Type } & \multicolumn{2}{|c|}{ Fraction of modern } & \multicolumn{2}{|c|}{ Radiocarbon age } \\
\cline { 4 - 7 } & & & pMC & $1 \sigma$ error & BP & $1 \sigma$ error \\
\hline D-AMS 033689 & Sample \#9 & sediment(humin) & 87.96 & 0.29 & 1031 & 26 \\
\hline
\end{tabular}

Results are presented in units of percent modern carbon (pMC) and the uncalibrated radiocarbon age before present (BP). All results have been corrected for isotopic fractionation with an unreported $\delta^{13} \mathrm{C}$ value measured on the prepared carbon by the accelerator. The pMC reported requires no further correction for fractionation.

11822 North Creek Parkway N, Suite \#107, Bothell, WA 98011

Tel (425) 481-8122 - www.DirectAMS.com

Page 1 of 1 


\section{Appendix D: Macrobotanical Identification Reports}

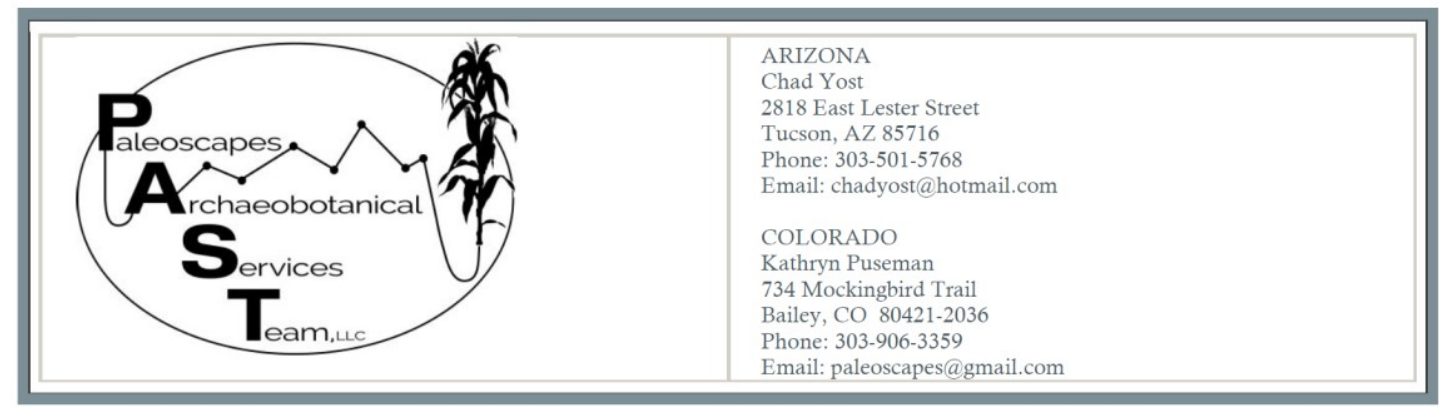

$2-25-2019$

PAST Project 19016

Identification results for wood from Sauvie Island, Oregon, are as follows:

\begin{tabular}{|c|c|c|l|l|}
\hline & & \multirow{2}{*}{ Identification } \\
\cline { 4 - 5 } D-AMS ID & Sample ID & Material & Scientific Name & Common Name \\
\hline $2149-32092$ & 1 & Wood & Thuja plicata & Western redcedar \\
\hline $2149-32094$ & 3 & Wood & Thuja plicata & Western redcedar \\
\hline
\end{tabular}

Wood fragments were broken to expose fresh tangential, radial, and cross-sections, then examined under a Bausch and Lomb Stereozoom microscope at a magnification of 70x and a Nikon Optiphot 66 microscope at magnifications of 100-600x. Both wood fragments were identified as Thuja plicata (western redcedar), based on the presence of tracheids with bordered pits in 1-2 rows on the radial wall, taxodioid cross-field pits, uniseriate rays measuring 1-12+ cells in height, and the absence of resin canals. These trees have average life spans of 300-700 years, although many trees live for over 1,000 years. A Thuja plicata tree with 1,460 rings was found along Canoe Creek in Olympic National Forest, Washington (The Gymnosperm Database). Please feel free to contact me if you have any questions.

Sincerely,

Kathryn Puseman 


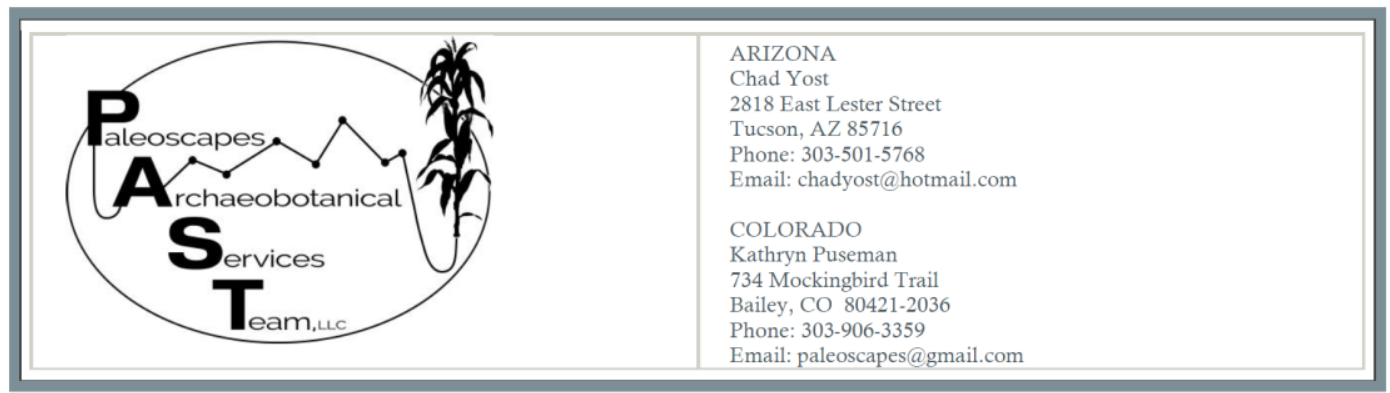

3-27-2019

PAST Project 19016.2

Identification results for additional wood sample from Sauvie Island, Oregon, are as follows:

\begin{tabular}{|c|c|c|l|l|}
\hline & & \multirow{2}{|c|}{ Identification } \\
\cline { 4 - 5 } D-AMS ID & Sample ID & Material & Scientific Name & Common Name \\
\hline $2149-32093$ & 2 & Wood & Thuja plicata & Western redcedar \\
\hline
\end{tabular}

The wood fragment was broken to expose fresh tangential, radial, and cross-sections, then examined under a Bausch and Lomb Stereozoom microscope at a magnification of 70x and a Nikon Optiphot 66 microscope at magnifications of 100-600x. This wood fragment was identified as Thuja plicata (western redcedar), based on the presence of tracheids with bordered pits in 1-2 rows on the radial wall, taxodioid cross-field pits, uniseriate rays measuring 1-12+ cells in height, and the absence of resin canals. Please feel free to contact me if you have any questions.

Sincerely,

Kathryn Puseman 


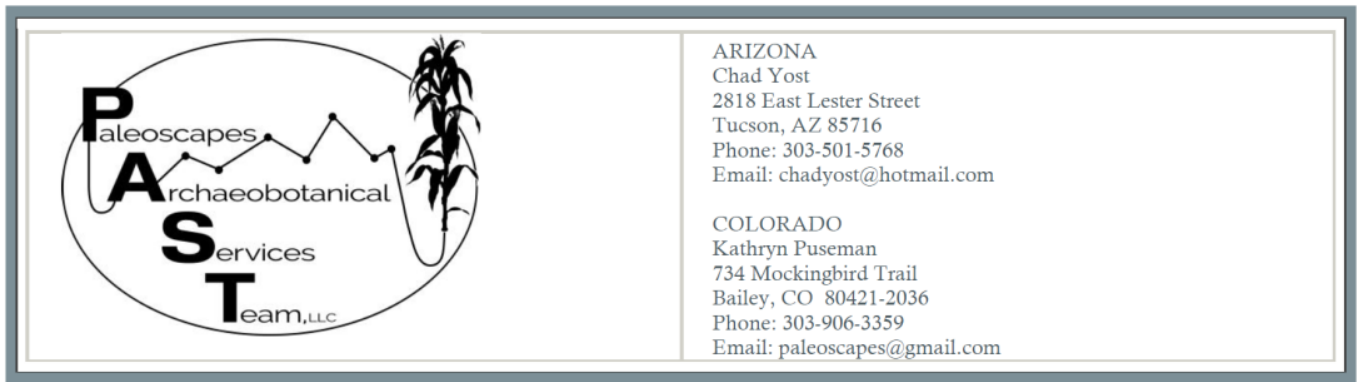

5-20-2019

PAST Project 19032

Identification results for additional wood samples from Sauvie Island, Oregon, are as follows:

\begin{tabular}{|c|c|c|l|l|}
\hline & & & \multicolumn{2}{|c|}{ Identification } \\
\cline { 4 - 5 } D-AMS ID & Sample ID & Material & Scientific Name & Common Name \\
\hline $2149-33449$ & Sample 4 & Wood & Thuja plicata & Western redcedar \\
\hline $2149-33450$ & Sample 5 & Wood & Thuja plicata & Western redcedar \\
\hline $2149-33451$ & Sample 6 & Wood & Thuja plicata & Western redcedar \\
\hline
\end{tabular}

The wood fragments were broken to expose fresh tangential, radial, and cross-sections, then examined under a Bausch and Lomb Stereozoom microscope at a magnification of 70x and a Nikon Optiphot 66 microscope at magnifications of 100-600x. All three wood fragments were identified as Thuja plicata (western redcedar), based on the presence of tracheids with bordered pits in 1-2 rows on the radial wall, taxodioid cross-field pits, uniseriate rays measuring 1-12+ cells in height, and the absence of resin canals. Please feel free to contact me if you have any questions.

Sincerely,

Kathryn Puseman 


\section{Appendix E: In-Situ Stake Recording Form}

\section{Stake Recording Form}

Stake \#:

Height from Ground:

Max Width at Base:

Max Width at Top:

Condition:

Shape:

Comments:

Photos \#s? 